\title{
Sedimentation patterns during the Precambrian: a unique record?
}

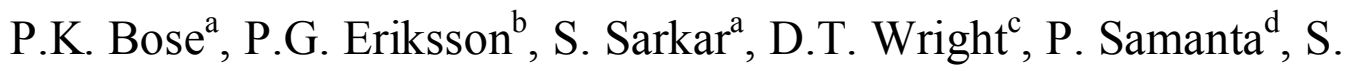

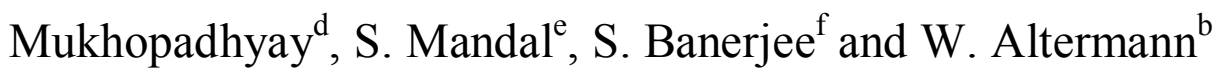 \\ ${ }^{a}$ Department of Geological Sciences, Jadavpur University, Kolkata-700 032, India \\ ${ }^{b}$ Department of Geology, University of Pretoria, Pretoria 0002, South Africa \\ ${ }^{c}$ Department of Geology, University of Leicester, University Road, Leicester LE1 7RH, United \\ Kingdom \\ ${ }^{d}$ Department of Geology, Durgapur Govt. College, Durgapur-713214, India \\ ${ }^{e}$ Department of Geology, Asutosh College, Kolkata-700 026,India \\ ${ }^{f}$ Department of Earth Sciences, IIT Bombay, Powai, Mumbai-400076, India
}

\begin{abstract}
Although the similarities between depositional processes and products as well as the analogous controls on basinfilling and evolution appear to have enjoyed great uniformity throughout the sedimentary rock record, a noticeable distinction exists in the rates and intensities of a broad range of geological processes in the Precambrian epoch. This paper searches for distinctiveness in the Precambrian sedimentary record, both siliciclastic and carbonate, through an extensive, though not exhaustive, review of the relevant literature augmented by new observations. While differences in Precambrian deltaic, aeolian, glacial and possibly also lacustrine deposits and settings appear to have been small, their large-scale development was controlled largely by a combination of temporal and geodynamic influences, essentially of global compass. In this regard the onset of the supercontinent cycle and major perturbations in palaeo-atmospheric composition appear to have been significant. Marine environments provide a
\end{abstract}


poor platform for Precambrian - Phanerozoic comparisons of sedimentation patterns, as those from the former period are preserved almost exclusively in epeiric settings, an environment essentially lacking on modern Earth. For the shallow marine carbonates, biological mediation of chemical sediment deposition changed radically from dominance by microbial biota in the Precambrian to a combination of metazons, protozoans and algae for the skeletal carbonates of the Phanerozoic. Despite it being widely recognized that Precambrian channel systems were braided in all environments (deltaic, tidal, alluvial, fluvial) as a consequence of the lack of vegetation and poor development of soils, the fluvial setting has some enigmatic aspects. Amongst these is evidence for ponding of muddy detritus in apparently sandstone bed-load dominated braided systems, with effects on local palaeoslopes which have resulted in unusual palaeohydraulic parameters for Precambrian fluvial systems. This is perhaps a field of research which holds greater promise when investigating sedimentation patterns prior to the Phanerozoic.

Keywords: Precambrian Eon; Sedimentation patterns; Process-product distinction; Siliciclastic-carbonate; Major environments; Features with Precambrian bias

\section{Introduction}

Many readers might question the title of this paper: why do Precambrian sedimentation patterns even merit special attention at all? Examination of most widely accepted treatises on sedimentary geology shows little attention devoted to Precambrian sedimentation per se, and a preponderance of papers published in the leading journals deals with the Phanerozoic sedimentary record. Some of the reasons for this are merely historical, in that in the Northern Hemisphere (specifically in Europe and North America that until recently dominated scientific publishing in the field), Phanerozoic rocks are much more widespread, and easily accessible; the global hydrocarbon industry has long dominated employment of those concerned with the sedimentary record on Earth, and this commodity is largely obtained from Phanerozoic basins. It 
is entirely logical that most studies of aspects like sedimentary processes, depositional models, the facies themselves, and more recently, the concepts inherent in sequence stratigraphy (e.g., Catuneanu, 2006) have been based on Phanerozoic exposures - apart from mere availability, this record is better preserved and its generally good fossil record allows much greater detail in facies definition, and biostratigraphic subdivision and correlation.

However, seen from a purely chronological perspective, the Phanerozoic record would appear to be a poor candidate to base sedimentary studies upon: the Precambrian record comprises about $85 \%$ of Earth history, and as an added bonus accounts for approximately $75 \%$ of global mineral resources (e.g., large quantities of $\mathrm{Au}, \mathrm{Pt}, \mathrm{Cr}$; most $\mathrm{FE}$ and $\mathrm{Mn}$ deposits; even some hydrocarbons, coal and graphite in the Neoproterozoic; Altermann and Corcoran, 2002b). The oldest indirect evidence of sedimentation (i.e., evidence for the presence of liquid water on Earth; e.g., Wilde et al., 2001; Bibikova, 2010) dates back to about 350 my after the formation of the planet (e.g., Eriksson et al., 2005); the oldest known supracrustal deposits, within the Isua greenstone belt of West Greenland, $>3.8 \mathrm{Ga}$, include chert, banded iron formation (BIF), and lesser conglomerates and sandstones (e.g., Fedo et al., 2001). It may thus be assumed that a broad spectrum of sedimentation accompanied formation of the earliest continental crust and has continued ever since. It is obeisance to the principle of modern uniformitarianism (cf., simplified often to "the present is the key to the past"; e.g., Hallam, 1990) that has confirmed the belief by many that the Phanerozoic sedimentary record is fully adequate to understand the processes and products of global sedimentation throughout Earth history (see discussion in Donaldson et al., 2002).

Certainly, amongst the most important fundamental principles of sedimentation patterns over time must be the observation that Precambrian sedimentary lithologies and the sedimentary 
structures they bear, as well as their interpreted genetic processes and settings, almost all have modern equivalents (e.g., Eriksson et al., 1998, 2004b; Altermann and Corcoran, 2002a). Indeed, the similarities between the Precambrian and the Phanerozoic-Modern sedimentary records far outweigh their differences (e.g., Eriksson et al., 2005), and the range of basin types and their fills in both time periods show no meaningful deviations from a common thread. Nor do the inferred origins of basins reflect anything other than a common interaction of first-order plate tectonic and mantle thermal processes with second-order modification by eustasy and palaeoclimate (e.g., Eriksson et al., 2001a, 2004a; Bose et al., 2001). The second fundamental principle of sedimentation patterns over time is possibly of even greater importance: the main difference between Precambrian and younger sedimentary settings lay in the variability of the rates and intensities of processes controlling weathering, erosion, transport, deposition, lithification and diagenesis in the Precambrian (e.g., Donaldson et al., 2002; Eriksson et al., 2005). This principle can apply equally to fundamental controls on uplift, sediment supply and creation of accommodation, through variable rates of crustal growth, plate movement and heat flux from the mantle (e.g., Eriksson et al., 2004a, and references therein), but this is a topic beyond the focus of the current paper.

What is most noticeably different for the Precambrian time period is the lack of vegetation and the limited development of soils, which directly affected erosion and sediment supply rates; the lack of bioturbation, allowing better preservation of fine sedimentary detail (yet balanced against the greater likelihood of deformation and metamorphism); the greater penetration depth of light through seawater on marine shelves due to a lack of plankton, allowing carbonates to develop at greater photic depths; the pervasive growth of microbial mats within shallow water and even subaqueous terrestrial environments, affecting both clastic and chemical sediment 
deposition and even architecture (e.g., Donaldson et al., 2002; Eriksson et al., 1998, 2000, 2004a, 2005; Sarkar et al., 2005; Catuneanu, 2006; Schieber et al., 2007; and references therein). Precambrian river deposits were almost exclusively braided (e.g., Schumm, 1968; Cotter, 1978; Long, 1978; see, however, Jackson, 1978), although the influence of muddy sediment within active channel systems rather than forming the floodplains bounding channels might have been more important, with evidence for strongly episodic flow patterns and enhanced gradients being derived from detailed palaeohydrological studies of temporarily mud-carrying braided systems (e.g., Eriksson et al., 2008a, 2009a).

Aeolian ergs are absent prior to c. $1.8 \mathrm{Ga}$, although evidence for localized wind deposition is much older (c. 3.0-2.8 Ga); formation of large deserts might be related to the antiquity of the supercontinent cycle (Eriksson and Simpson, 1998; Simpson et al., 2004a). More uniform shelf circulation and storm patterns, a lack of preserved barrier island deposits and a predominance of preserved epeiric marine basins rather than open ocean basins typify the Precambrian record (e.g., Eriksson et al., 1998, 2004b and references therein), all of course predicated on the nonpreservation of ocean crust older than Jurassic, implying that Precambrian marine deposits are mostly limited to preserved epeiric basins. Iron formations (IF) comprise a truly uniquely Precambrian lithology, whose origin remains the subject of much debate (e.g., Trendall, 2002); their origin has been related by many to evolution of palaeo-atmospheric compositions over time, although they may merely reflect basin formation at the approximate depths of the pycnocline on a planet already colonized by significant cyanobacterial colonies producing shallow oxygenated waters (e.g., Trendall and Blockley, 2004). Their character and possible origins would require a separate paper and they will thus not be considered in any detail in this contribution, which restricts itself essentially to siliciclastic and carbonate sedimentation systems. 
The ongoing debate on atmospheric and hydrospheric chemical evolution during the Precambrian rests directly on study of the concomitant sedimentary record, with change from an original reducing atmosphere to a more oxidizing composition inherent in most views, although not all (e.g., Ohmoto, 2004, for a review). It is to address all of these aspects briefly that the present paper is presented, as a necessary background to better appreciate the complexities related to global correlation of accommodation curves (derived from the sedimentary record) across Precambrian cratons, which is the theme of this special issue. The Precambrian sedimentary record is addressed through separate sections for siliciclastic and carbonate deposits. All the major depositional environments are discussed under the clastic heading, in exclusion of only the glacial environment which is included at the end of the carbonate section, due to the inferred close relations between palaeo-atmospheric and palaeo-hydrospheric evolution, carbonate deposition (and specifically C isotopes found in "cap carbonates" associated with glacigenic deposits) and global-scale glaciation. Since distinction of the Precambrian sedimentation record is the primary issue, the paper also brings focus to some sedimentary features that have a clear Precambrian bias in occurrence.

\section{Siliciclastic depositional systems}

\subsection{Introduction}

As Precambrian crustal evolution progressed, potential source terrains for clastic sediments would have changed over time, as did the palaeo-atmospheric and-hydrospheric chemical environments. Together, these highly complex and interacting processes would have largely 
determined the composition of detrital sediments within the pre-Phanerozoic rock record, with additional controls being provided by sediment sorting and energy levels inherent in the transport and depositional processes themselves. It is inferred by a majority of scientists that the early Precambrian (cf. Archaean) was characterised by conditions best described as "weatheringaggressive" (Corcoran and Mueller, 2004). These would have been caused by the combination of high levels of heat, humidity, and greenhouse gases like $\mathrm{CO}_{2}$ and $\mathrm{CH}_{4}$ (e.g., Young, 1991; Kasting, 1993; Des Marais, 1994; Pavlov et al., 2001; Kasting and Siefert, 2002). As a result of this intense Archaean weathering regime and an absence of binding vegetation, labile minerals and unstable rock fragments would have been rapidly broken down to form clay minerals, which were swiftly separated by sediment transport and sorting agents from the predominant quartz and accessory heavy mineral grains more resistant to chemical breakdown (Corcoran and Mueller, 2004). By using the Chemical Index of Alteration (CIA; Nesbitt and Young, 1982), Condie et al. (2001) were able to demonstrate a gradual decline in weathering intensity over geological time, related to change in palaeo-atmospheric composition: average CIA values for Archaean shales of 80, declined to 75 in the Proterozoic and to 70 in Phanerozoic shales. Obviously, sediment recycling (estimated to be c. $90 \%$ in post-Archaean times by Veizer and Jansen, 1985) also needs to be taken into account here, but first cycle sediments can generally be recognised (although not exclusively) on the basis of textural immaturity (Corcoran and Mueller, 2004).

Another aspect to be addressed within Archaean clastic deposits is the so-called "quartz budget problem" (cf., Pettijohn, 1970, 1972). The basis of this paradox is the expectation that detrital deposits within Archaean greenstone terranes would have formed within a tectonic framework of great instability with concomitant rapid creation of accommodation related to inherently unstable basin-forming and subsidence mechanisms; as a result, highly immature 
compositions and textures should have formed (e.g., Donaldson and de Kemp, 1998). However, this is not the case, and numerous mature to even supermature quartz arenites are known from the Canadian Shield and many other ancient cratonic areas, where they show a relatively common spatial association with mafic volcanic rocks (Donaldson and de Kemp, 1998). The latter authors point out the associated problem of where these sediments might have been sourced, and deduce that phanerocrystalline granitoid rocks as well as recycling of existing sedimentary strata offer the best possible solutions. Once again, as in the previous paragraph, weathering-aggressive conditions are implicit, together with relatively high energy transport systems, as well as the likely necessity for prolonged periods of crustal stability within the overall active tectonic framework of Archaean crustal development (Donaldson and de Kemp, 1998).

Within the Proterozoic, particularly the Palaeoproterozoic (and assuming this to be a period of essentially post-cratonisation character), it could be assumed that the development of relatively stable cratons and probably also of the first supercontinents (e.g., Aspler and Chiarenzelli, 1998), allied to a still-reducing palaeo-atmosphere would have resulted in a detrital sedimentary record dominated by compositionally more mature sediments. This line of reasoning is complicated by the debate over the "Great Oxidation Event" at some time between about 2.35 and 2.0 Ga (e.g., Ohmoto, 2004; Lindsay and Brasier 2004; see also Eriksson et al., this volume) and the influence this may have had on the efficiency of the extant palaeo-atmosphere to break down source material. Some workers (e.g., Sheldon, 2006; Eriksson et al., 2009a) dispute any significant lessening of the greenhouse atmosphere for the c. 2.5-1.8 Ga period at all. Within this framework, it is interesting to examine, very briefly, the petrology of the clastic sediments of the 
Pretoria Group (Transvaal Supergroup, Kaapvaal craton; c. 2.35-2.05 Ga) which fall almost exactly within this much debated time period.

The Pretoria Group comprises a maximum thickness of $6100 \mathrm{~m}$ of predominant alternating mudrocks and sandstones with lesser basaltic andesites, and subordinate conglomeratic and carbonate rocks (e.g., Eriksson et al., 2001b). A tectonic setting comprising two episodes of rifting followed by much longer periods of thermal subsidence is inferred (Eriksson et al., 2001b). Detailed petrographic studies of 170 sandstone thin sections around the basin provide the following proportions of rock types (after Pettijohn et al., 1972): quartz arenites (31\%), lithic arenites $(20.5 \%)$, arkosic arenites $(21.5 \%)$, lithic wackes $(14 \%)$, feldspathic wackes $(9.5 \%)$ and quartz wackes (3.5\%) (based on detailed data in Schreiber et al., 1991, 1992). Essentially thus, this well-studied Palaeoproterozoic example provides an extension of the Archaean "quartz budget" paradox - within a much less active tectonic setting and following cratonisation, more mature sandstones would be expected to have formed, but a contrary trend is, again observed. Proponents of the "Great Oxidation event" could easily ascribe this to significant change from a greenhouse atmosphere to a partially oxidising one, with concomitant decrease in weathering intensities; this would be supported by the possibly global c. 2.4-2.2 Ga glaciation event (e.g., Young, 2004). However, even under Phanerozoic-Modern atmospheric conditions, deposition of large quantities of feldspathic and lithic sandstones could argue in favour of rapid sedimentation processes rather than cold climatic conditions.

Although some workers do challenge any significant oxidation of the palaeo-atmosphere within the Palaeoproterozoic (e.g., Sheldon, 2006; Eriksson et al., 2009a), possible differences in the tempos and intensities of sedimentation systems may also have played a role in explaining the apparent conundrum. Eriksson et al. (2009a) suggest that strongly episodic yet high energy 
fluvial systems fed equally episodic marine coastal clastic systems on many of the cratons in the Palaeoproterozoic; they relate these intermittent yet high energy sediment supply and depositional events to the overall influence of a still strongly reducing greenhouse palaeoatmosphere. Comparison of Precambrian and Phanerozoic-Modern sedimentation rates is fraught with difficulty, for at least two reasons: the resolution of c. 1-5 my for radiometric dating of Precambrian rocks, and the very wide range in the more recent rates, varying from $10^{1}$ to $10^{6}$ Bubnoff units $\left(\mathrm{mmky}^{-1}\right)$ (e.g., Eriksson et al., 2004c). However, it is possible that such episodic sediment supply and rapid transportation and depositional events combined, in conjunction with generally slower rates of accommodation creation in the Palaeoproterozoic, may explain the sandstone composition conundrum in that part of the rock record, as can the importance of weathering-aggressive atmosphere composition account for the "quartz budget problem" in the Archaean (cf., Donaldson and de Kemp, 1998). Palaeo-atmospheric and palaeohydrospheric evolution will be further addressed under the carbonate sedimentation section of the paper.

\subsection{Fluvial systems}

A widely held consensus on Precambrian fluvial systems is that they were characterized by broad channel systems on very large braidplains, enhanced rates of channel migration, high discharge rates and flashy surface runoff, abundant bed-load, and that they lacked bank stability due to an absence of plants and to poorly-developed soils; braided systems would consequently have predominated (e.g., Schumm, 1968; Cotter, 1978; Long, 1978, 2004; Fuller, 1985; Els, 1990; Rainbird, 1992; Eriksson et al., 1998; see however, Jackson, 1978). Their scale, lack of bank stability and faster runoff rates would doubtless have made these river systems more 
susceptible to palaeoclimatic change, and concomitantly, ephemeral rivers probably occurred through a broader climatic range than Phanerozoic-Modern systems (Tirsgaard and Øxnevad, 1998). In general, models of bed-load dominated, sheet-like, braided alluvial deposits (cf. the Scott and Donjek types identified by Miall, 1977, 1978, 1996) are most often espoused for the Precambrian (Long, 2004). Identification of incontestable channel elements, or even channel margins, remains rare (Long, 2004).

Identified alluvial fan deposits are not common in the Precambrian record, their proximal positions affecting preservation (e.g., Els, 1998; as a caveat, however, see Mueller and Corcoran, 1998). The latter authors (also, 2001) point out that pyroclastic debris in Archaean greenstone belts commonly suffocated alluvial channels, leading to prominence of hyperconcentrated flood flow and sheetflood deposits in such systems. The weathering-aggressive atmosphere in the Archaean would have resulted in more muddy detritus entering river systems, also thus promoting such flood flow and sheetflood deposits (cf., Donaldson and de Kemp, 1998; Corcoran et al., 1998). Long (2004) points out that debris-flow deposits may thus well have occurred in non-fan fluvial systems as well (e.g., Buck and Minter, 1985; Pflüger and Seilacher, 1991; Eriksson et al., 2008a, 2009a). Despite the expected large volumes of muddy sediment, identified examples of high-sinuosity river deposits (e.g., Sweet, 1988; however, disputed when compared to Rainbird, 1992; see discussion in Long, 2004) are rare.

Discrimination of fan and fluvial braidplain deposits should logically best be achieved through the criteria outlined by Blair and McPherson (1994), particularly the "natural depositional gap" separating the gradients of fans $(>0.026 \mathrm{~m} / \mathrm{m})$ and rivers $(<0.007 \mathrm{~m} / \mathrm{m})$. However, palaeohydrological results from c. 2.05-1.8 Ga alluvial deposits from the Kaapvaal craton (discussed below) coincide almost exactly with this gap (e.g., Van der Neut and Eriksson, 
1999; Eriksson et al., 2008a, 2009a). Architectural element analysis of Precambrian fluvial deposits has been relatively limited (e.g., Long, 2004 and references therein) as has been establishing sequence stratigraphic frameworks (e.g., Ramaekers and Catuneanu, 2004; Eriksson and Catuneanu, 2004a). Below we briefly discuss two examples of Precambrian river systems, from the Neoproterozoic Sonia Formation in India, and from the Palaeoproterozoic Waterberg Group of Kaapvaal.

Studies of the facies and architectural elements within a sequence stratigraphic framework in the fluvial interval at the base of the Neoproterozoic Sonia Sandstone (Jodhpur, Rajasthan, India) (Fig.1) identifies at least some reasons for Precambrian river channels shedding their usual mobile (i.e., braided) nature (Samanta et al., 2007, 2008; Samanta, 2008). Confined between a rhyolitic basement ( $\sim 600 \mathrm{Ma}$ ) and a transgressive lag flooring a coastal interval above (Samanta, 2008; Sarkar et al., 2005, 2008), the three divisions of the Sonia fluvial interval are superposed one above the other and each is fining-upward, together giving rise to an overall fining-upward trend (Fig. 2; Sarkar et al., 2008). The middle division is, however, the coarsest, being pebbly in its lower part. Mudstone is completely absent in this division, but is present marginally in the lower and substantially in the upper divisions.

An additional difference between the fluvial divisions also exists in the abundance of aeolian products in them, being substantial in the middle, restricted in the lower and subordinate in the upper division; the river system was apparently ephemeral in the middle, perennial in the upper and probably semi-perennial in the lower division. Recorded channel flow direction veers selectively from a predominant westward- to southwestward-oriented trend in the middle division. Apparently, the palaeoslope direction altered significantly between the divisions. The top eight metres of the middle division selectively bears soft sediment deformation structures, 
which are pervasive all over the $1800 \mathrm{~km}^{2}$ study area. The role of tectonism in partitioning the Formation into its three component divisions is thus amply demonstrated.

Further differences exist between assemblages of fluvial architectural elements (Miall, 1985, 1996, 2006; Willis, 1997; Halbrook, 2001; Yu et al., 2002; Miall and Jones, 2003; LumsdonWest and Plint, 2005; Alexander and Fielding, 2006; Halbrook et al., 2006; Labourdette and Jones, 2007) identified within the three divisions (Samanta, 2008). The Sandy Lateral Accretion element dominates over Downsream Accretion elements in the lower and the upper divisions of the fluvial interval of the Sonia Formation, while not a single example of the former was encountered in the middle division. There is little difference, however, in the abundance of the Small Channel element, except that it is relatively more tabular in geometry in the lower division. The Laminated Sand Sheet element is present in all three divisions, but in the form of levee facies, is developed only marginally in the lower division and profusely in the upper division, while being completely absent in the middle. The same is true for the Flood Plain element. Laminated Sand Sheet elements in the form of crevasse splay facies encased in either Flood Plain elements or Inclined Heterolithic Strata (IHS) elements, and separated from Sandy Lateral Accretion elements on the basis of geometry and structure, are exclusive for the upper division, especially its top part. The Sandy Bedform element is rare for all three divisions.

Surfaces bounding the three divisions are readily correlatable all over the study area and define three different aggradational valley cycles, palaoslope changing significantly between them. Taking the transgressive surface that terminates the fluvial interval of the Sonia Sandstone at its top as a near-horizontal datum plane, and correlating the division boundaries observed in vertical sections distributed along two near-orthogonal transects, makes the three-dimensional geometries of successive valley cycles amenable to reconstruction (Fig. 3). It is amply clear from 
the reconstruction that fluvial aggradation was initiated, presumably after the maximum fall of the river base profile and deepest incision (cf., Blum and Tornqvist, 2000), in a constricted valley cut into the basement. Rapid widening of the valley, apparent at the transition from the basal to the middle division, is attributable to base profile rise or to base profile fall at a slow rate (cf., Whipple et al., 1998; Strong et al., 2005). A sharp increase in sediment grain-size across the transition testifies to an increase in flow velocity and higher water discharge despite rapid expansion of the drainage area, and thus favours profile rise, but possibly with source uplift; the observed change in channel flow direction makes the tectonic effect apparent.

Flood plain amalgamation in the upper Sonia fluvial division is a definite indication for an enhanced rate of base profile rise. Rapid basin subsidence ushered in transgression of the sea, although the study area was inundated only later. Relative rise of base profile, nonetheless, induced a tendency for ponding and allowed mud to settle at the downstream end of the river valley in ever increasing amounts, until the sea flooded the entire area; the river channels, in the meantime, became fixed. Tidal influence expected during drowning of the river system is evident only perhaps in the HIS architectural elements, observed exclusively within the top part of the upper division.

It thus appears that Proterozoic river channels may have tended to become fixed in Falling Stage Systems Tracts (FSST) and at the beginning of Lowstand Systems Tracts (LST) when the river valleys are likely to be narrow and may be incised within hard bedrock. Otherwise, Proterozoic rivers were destined to be braided because of the inherent instability of their banks, devoid of vegetation. However, during the closure of the Lowstand Systems Tract also, with an enhanced rate of rise of relative sea level, the Proterozoic rivers tended to become 
fixed, meandering or even anastomosed because of bank stability gained through increased mud settling.

The c. 2.0-1.8 Ga (Walraven and Hattingh, 1993; Eglington and Armstrong, 2004; Hanson et al., 2004) Waterberg Group is amongst those units globally, containing the first red beds sensu stricto (reflecting free oxygen in the palaeo-atmosphere) and relatively large erg deposits (e.g. Eriksson and Cheney, 1992; Eriksson and Simpson, 1998). These sedimentary beds were laid down within two basins on the Kaapvaal craton (Fig. 4) and are dominated by fluvial deposits, with lesser desert, fan and lake sediments (Callaghan et al., 1991; Simpson et al., 2002, 2004b). Both basins are bound by fundamental Archaean structures within the Kaapvaal craton (Callaghan, 1991; Eriksson et al., 1996). The large Waterberg basin contains 11 formations and the small one, a single formation, the Wilgerivier; this later unit and the Mogalakwena Formation from the large (Main) basin have been studied in detail to try and unravel the nature of their fluvial deposits (Van der Neut and Eriksson, 1999; Bumby, 2000). The deposits of the c. $2.0 \mathrm{Ga}$ Blouberg Formation, which is unconformably succeeded by Waterberg rocks, have also been studied in detail; all three units comprise analogous fluvial deposits (Eriksson et al., 2008a and references therein).

The Mogalakwena Formation comprises cyclically interbedded sheets (0.5-1.0 m thick, 100's of metres in extent in outcrop) of medium- to coarse-grained sandstone or granulestone, and matrix-supported, largely massive conglomerate sheets (Bumby, 2000). These cycles generally fine upwards, and are equated with architectural element CHS (major sandstone sheet; Miall, $1985 ; 1996)$. The sheets are cut locally by conglomeratic channel-forms (architectural element $\mathrm{CH}$ of Miall, 1985, 1996), 20-30 m across, and 2-5 m deep. Common trough cross-bedding with a consistent unimodal palaeocurrent trend characterizes the predominant sandstone-granulestone 
sheets (Bumby, 2000). A general braided fluvial model is inferred for these deposits, and for those of the Blouberg and Wilgerivier Formations (Eriksson et al., 2008a). Applying standard palaeohydrological methodology to these three Waterberg braided fluvial formations indicates palaeoslope estimates which coincide almost precisely with the observed "natural depositional gap" separating alluvial fan gradients $(>0.026)$ and river slopes $(<0.007$; cf. Blair and McPherson, 1994) (Eriksson et al., 2006, 2008a) (Fig. 5).

Despite all three formations exhibiting typical low sinuosity-type fluvial facies and internally consistent and unimodal palaeocurrent patterns typical of braided river deposits, there are subordinate facies indicating sheetflow-sheetflood, debris-flow or density-modified grain flow deposition (Van der Neut at al., 1991; Bumby, 2000; Eriksson et al., 2008a). Eriksson et al. (2009a) postulate that temporary argillaceous sediment accumulations within these fluvial systems (related to aggressive greenhouse palaeo-atmospheric conditions providing more labile clay material within continental sedimentary systems) enabled higher palaeoslopes to develop locally, and also led to localized gravity-flow deposits within these braided systems. An analogue is provided by the Neoproterozoic Kuujjua Formation (Canadian Shield; Rainbird, 1992). Eriksson et al. (2009a) relate this strongly episodic style of fluvial sedimentation to either a continuation of a greenhouse palaeo-atmosphere at this time, or a more gradual or possibly even diachronous transition to a more oxygenated atmosphere than that implicit in the "Great Oxidation Event" (e.g., Holland, 2002) at some time between c. 2.35 and $2.0 \mathrm{Ga}$, at least for the Kaapvaal craton (see also, Voegelin et al., 2010, for comment on global redox changes and the Kaapvaal craton during the Neoarchaean-Palaeoproterozoic).

\subsection{Aeolian systems}


Wind ripple stratification is adequately diagnostic of aeolian processes to allow confident discrimination from aqueous sedimentation processes; supplementary diagnostic features include pin-stripe lamination, adhesion structures and coarse sand/granule ripples; together, such features equally allow identification of Precambrian aeolian deposits (e.g., Hunter, 1977, 1981; Kocurek and Dott, 1981; Kocurek and Fielder, 1982; Clemmensen and Abrahamsen, 1983; Fryberger et al., 1988, 1992; Clemmensen and Dam, 1993; Bose and Chakraborty, 1994; Eriksson and Simpson, 1998; Bose et al., 1999; Simpson et al., 2004a). Eriksson and Simpson (1998) distinguish various depositional settings or facies within the preserved Precambrian aeolian record: (1) draa deposits, normally large in extent and thickness, characterised by three orders of bounding surfaces (e.g., Brookfield, 1977); (2) non-recognition of the latter within inclined cross-strata comprised of combinations of wind-ripple, grainfall and grainflow deposits (Hunter, 1977; Kocurek and Dott, 1981), results in a classification as dune deposits; (3) dune plinth deposits are commonly associated with dune deposits as they occur at the base of dunes, but are distinguished by near-horizontal to horizontal wind-ripple stratification; (4) sand sheet deposits which are commonly comprised of coarser-grained (coarse-grained sand to granule calibres) low angle to horizontal inversely graded strata with adhesion structures (e.g., Fryberger et al., 1979). Sand sheet development is often linked to conditions which reduce dune formation, such as lower sand supply, high water table, surface cementation and binding (cf., vegetation) (Kocurek and Nielson, 1986); (5) interdune deposits occur between dunes and/or draas and typically include argillaceous sediments, a combination of aeolian and water-formed structures as well as evidence for desiccation. 
In their review of Precambrian aeolianites, Eriksson and Simpson (1998) find that such deposits become relatively common in the rock record from c. $1.8 \mathrm{Ga}$ onwards. In their list of twenty identified Precambrian aeolian deposits, only three (two members of the c. $<2.4->2.1 \mathrm{Ga}$ Kinga Formation, Canada, and the c. 2.1 Ga Deweras Formation, Zimbabwe) pre-date this c. 1.8 Ga age; most of the early deposits, including those prior to c. 1.8 Ga comprise dune and sand sheet types (Eriksson and Simpson, 1998). An association of these various aeolian deposits with either fluvial or shallow marine strandline facies is commonly observed, as is a rift-related tectonic setting (Eriksson and Simpson, 1998). Two more ancient windblown deposits have been recognised since this compilation: the Tamanduá Group in Brazil, and the Dhalbhum Formation in India (Simpson et al., 2004a).

The oldest recognised aeolian deposit is that within the $<2.70$ - $>2.42$ Ga Tamanduá Group (Minas Supergroup, SE Brazil) (Babinski et al., 1995; Machado et al., 1996; Simpson et al., 2004a). These deposits occur within a rift setting, overlie continental deposits of predominantly braided fluvial character, and are about $2500 \mathrm{~m}$ thick; they are interpreted as a sand sheet facies, characterised by decimentre- to metre-thick trough cross-beds, with locally complex crossstratification as well as interdune sediments (Martins-Neto and Costa, 1985; Simpson et al., 2004a). Within the Hearne crustal province of Canada, overlying inferred glacial deposits equivalent to the well-known Huronian Supergroup occurences is the Kinga Formation of the Hurwitz Group (e.g., Aspler and Chiarenzelli, 1998). The Maguse Member of this formation comprises both dune and sand sheet deposits, c. $<2.4->2.1 \mathrm{Ga}$, associated with fluvial deposits within an overall coastal aeolian complex (Patterson and Heaman, 1991; Aspler et al., 1992; Heaman and Le Cheminant, 1993). The Whiterock Member, interpreted to be a lacustrine deposit, exhibits adhesion structures reflecting an aeolian genesis (Aspler et al., 1994). 
The 2.3 Ga Dhalbhum Formation (Singhbhum craton, India) formed within an intracratonic rift basin, and is spatially associated with fluvial deposits; it includes a relatively thin (average 30 m) aeolian unit characterised by wind ripple laminae, translatent strata with both grainfall and grainflow laminae, isolated lenticular cross-bedded dune deposits (forming sets up to $40 \mathrm{~cm}$ thick) and adhesion structures (Mazumder et al., 2000, Simpson et al., 2004a). The latter authors note that the wind ripple laminae are stacked locally into sets of c. $20 \mathrm{~cm}$ thickness, separated by iron-stained, second-order surfaces that lack armour and which may have been non-erosional. The translatent strata are found locally associated with the aeolian ripples; the crinkled adhesion laminae occur as $\sim 6 \mathrm{~cm}$ thick sets. The aeolian features noted above commonly formed $\sim 90 \mathrm{~cm}$ thick cycles from basal adhesion laminae - translatent/ripple laminae - isolated cross-bedded dune sets at the tops, cycles being bound by extensive approximately planar erosion surfaces (Simpson et al., 2004a). A relatively high water table (preventing draa evolution) and low relief provenence close to sea level are inferred; the $\sim 90 \mathrm{~cm}$ thick drying-up cycles may have been influenced by palaeoclimatic fluctuations (Simpson et al., 2004a). The next younger known example of a Palaeoproterozoic aeolian deposit is from the c. $2.1 \mathrm{Ga}$ Deweras Group in NW Zimbabwe that bears large scale cross-beds with inversely graded stratification, associated with evaporites (Master, 1991) within inferred wind ripple deposits (Eriksson and Simpson, 1998). A relatively low water table is again implied.

From about $1.8 \mathrm{Ga}$, large and well-developed aeolian deposits become common in the rock record: e.g., erg deposits of the c. 1.85-1.75 Ga Baker Lake and Wharton Groups (Dubawnt Supergroup, Canada); dune, sand sheet, interdune and dune plinth deposits of the c. 1.8-1.74 Ga Bottletree Formation (Upper Mount Guide Quartzite, Mount Isa Orogen, Australia); draa and dune deposits of the c. 1.66->1.60 Ga Hornby Bay Group and Thelon Formation (NW Canada) 
(Eriksson and Simpson, 1998 and references therein). An excellent example of the first widespread aeolianites is given by the c. $2.0-1.85$ Ga Makgabeng Formation (Waterberg Group, Kaapvaal craton; see Fig. 4), which is interpreted to be an erg deposit (Meinster and Tickell, 1975; Callaghan et al., 1991; Bumby, 2000; Simpson et al., 2002, 2004b). The Makgabeng Formation is preserved over an extent in excess of $100 \mathrm{~km}$ in its longest dimension, reaches up to c. $800 \mathrm{~m}$ in thickness, and is bounded above and below by essentially fluvial deposits (Bumby et al., 2001; Eriksson et al., 2000). Despite having formed within a faultbounded depository (Bumby et al., 2001), its sediments locally prograded across at least one of the major bounding structural features (Bumby, 2000) suggesting thermal subsidence. The lower contact with underlying fluvial deposits is gradational (Callgahan et al., 1991), supporting the likelihood of palaeoclimatic deterioration; the upper contact is erosional (Bumby, 2000; Eriksson et al., 2000). By far the predominant facies within the Makgabeng palaeo-desert deposits is ascribed to aeolian origin, and comprises texturally and mineralogically mature fine-grained sandstones with either straight-crested or barchanoid dune cross-bedding (Fig. 6), with set thicknesses mostly between 1 and $3 \mathrm{~m}$ with a maximum recorded of $15 \mathrm{~m}$ (Eriksson et al., 2000). Within the best exposed area (Makgabeng plateau, where about $300 \mathrm{~m}$ of vertical succession can be studied), Makgabeng aeolianites exhibit a medial planar cross-bedded succession, sandwiched between barchanoid trough cross-bedded successions. Towards the top of this vertical aeolian transition, four interdune beds (40-110 cm thick) are exposed over $5 \mathrm{~m}$ of thickness and extend laterally for about $100 \mathrm{~m}$; these four lenticular beds exhibit planar laminations, wave, current and combined flow ripples, mudcracks superimposed on the ripples, possible evaporate casts, as well as muddy "roll-up" structures indicating desiccation and subsequent reworking of microbial mats by sheetfloods (Eriksson et al., 2000; Simpson et al., 2002). Locally, erosively-based massive 
sandstones are interbedded with the lower portions of aeolian cross-bed sets and dune toesets (Fig. 7), indicating genesis through mass-flow processes related to significant precipitation events; hyperconcentrated flows are inferred to have flowed down dune lee faces and eroded into them, with lobate deposits resulting on the dune plinths (Simpson et al., 2002). Several metres above the uppermost interdune bed, Simpson et al. (2004b) documented saline pan deposits, up to about $2 \mathrm{~m}$ in thickness, with facies stacking patterns suggesting flooding and desiccation cycles of variable lengths (estimated at months to hundreds of years). Although not large by current erg sizes, the Makgabeng counts as one of Earth's oldest such deposits, and exhibits most of the features to be observed in any Phanerozoic - Modern desert succession, with strong evidence for an interplay of temporally dominant aeolian and subordinate aqueous processes and products (Eriksson et al., 2000, Simpson et al., 2002, 2004a and b).

By the Neoproterozoic, ergs had become common within the Precambrian record, as for example in the $0.6 \mathrm{Ga}$ Upper Bhander Sandstone. It is the topmost Member of the Bhander Formation of the Vindhyan Supergroup, best studied in Rampur Hills, skirting Maihar in central India (Fig. 1; Bose et al., 2001). Resting on the overall prograding marine shelf succession of the coeval Sirbu Shale, this Member is dominantly non-marine, marking the penultimate stage of sedimentation within an intracratonic sag basin (Bose et al., 1999, 2001; Sarkar et al., 2002a; Ray, 2006). Parasequences, separated by gently seaward dipping convex-upward erosive surfaces, comprise this Member. Individual parasequences bounded below and above by secondorder superbounding surfaces, are upward-drying with interdune sand-sheet deposits passing upward into dune and draa deposits. The lower part of each parasequence is dominated by adhesion laminae, followed upward by translatent strata encasing solitary sets of dune laminae in the middle part and multiple dune-cross beds, locally made up of longitudinal dunes, in the top 
part (Bose et al., 1999). Thickness of parasequences, as well as thickness of draa deposits on top of some of the parasequences, tends to increase landward. The marine flooding surfaces defining individual parasequences, however, rapidly disappear in an inferred landward direction. Relatively thin fluvial and lacustrine beds intermittently disrupt the record of otherwise continuous aeolian deposition. As a whole, the major part of the Upper Bhander Sandstone represents an erg deposit with a seaward counterpart of marine supralittoral storm bed packages.

Explaining the temporal distribution of aeolian deposits in the Precambrian record is complex. Eriksson and Simpson (1998) discuss various explanations such as an absence of vegetation, crustal growth rates, tectonic setting, eustasy and local sea level changes, palaeoclimatic conditions, fluvial reworking and non-recognition. They note a c. 600 my gap between significant continental crustal growth rates and cratonisation (at. c. $2.4 \mathrm{Ga}$ ) and the development of widespread large-scale aeolianites globally at c. $1.8 \mathrm{Ga}$.

The oldest known evidence for aeolian sedimentary activity is from ventifacts found within the c. 3.0-2.8 Ga Witwatersrand basin, Kaapvaal craton (e.g., Minter, 1976). Prior to c. $1.8 \mathrm{Ga}$, no preserved erg deposits are known, and the relationship between aeolian and spatially associated fluvial deposits as well as a rift-related tectonic setting is striking. Although it is a contentious issue, supercontinentality may already have begun on Earth in the Neoarchaean (e.g., Aspler and Chiarenzelli, 1998; see discussion in Eriksson et al., this volume). If this is so, then the oldest known aeolianites, from the $<2.70$ - $>2.42$ Ga Tamanduá Group are approximately coeval with earliest supercontinent development, and are followed by the Hurwitz Group and Dhalbhum aeolianites in the c. $2.45-2.1$ Ga period (see discussions in Eriksson and Simpson, 1998; Simpson et al., 2004a). However, supercontinentality only appears to have become widespread on Earth by about $2.2-1.8$ Ga (e.g., Eriksson et al., this volume), approximately 
coincident with widespread aeolianite development including the first ergs. The role of large continental land masses may thus have been critical. Also important was groundwater and fluctuations in the water table, in determining sand supply and preservation of aeolianites (Eriksson and Simpson, 1998).

Palaeoclimatic changes and fluvial reworking are harder to evaluate. The likelihood of a humid and warm palaeoclimate up till about $2.3 \mathrm{Ga}$ is agreed upon by most (e.g., Ohmoto, 2004), and this humid setting may have impaired aeolianite formation. The "Great Oxidation Event" at some time between about 2.35 and $2.0 \mathrm{Ga}$ (Ohmoto, 2004) would not have done much to encourage dry conditions, but may have been counteracted by increasingly large continental masses, with dry interiors. However, some have questioned this oxidation event and find that the global greenhouse palaeo-atmosphere may have endured to at least $1.8 \mathrm{Ga}$ (e.g., Sheldon, 2006; Eriksson et al., 2009a). In such a case, a rift setting may have led to locally favourable palaeoclimatic conditions for sand sheet and even erg formation within a globally warm yet humid palaeoclimatic regime. Strongly episodic fluvial flooding events may have typified continental aqueous sedimentation regimes in the c. 2.3-1.8 Ga period (cf., Eriksson et al., 2009a), and this likely strongly influenced fluvial reworking of aeolian deposits also.

\subsection{Marine systems}

Degassing of Earth's mantle provided water to the palaeo-atmosphere, which condensed to form the early oceans by about $4.0 \mathrm{Ga}$ (c. $90 \%$ of current volume); early seawater was most likely acidic due to relatively high contents of dissolved $\mathrm{CO}_{2}$ and other acidic components like $\mathrm{H}_{2} \mathrm{~S}$ and HCL (e.g., Condie, 1997). However, volcanic eruptions and recycling of seawater at 
mid-ocean ridges would relatively rapidly have resulted in a "modern" ocean composition (Condie, 1997).

The long and complex history of early plate tectonics (in whatever form; see for example, discussion by Eriksson and Catuneanu, 2004b) followed by a more modern style of plate interactions in the c. $<2.0 \mathrm{Ga}$ period and by the subsequent Neoproterozoic and Phanerozoic regime of Wilson cycles as supercontinents formed and dispersed, resulted in marine deposits marginal to and adjacent to Precambrian cratons and terranes not generally being preserved. Essentially thus, Precambrian marine deposits comprise a record of epeiric seas rather than the remnants of open ocean margins, shelves and deep sea settings (Eriksson et al., 1998; 2004d). The Precambrian marine record must therefore be treated with some caution due to this preservational bias towards epicontinental sea deposits. Their study is not made any easier by a relative lack of true modern examples (e.g., Hallam, 1981; Galloway and Hobday, 1983; see also the recent treatise on epeiric seas edited by Pratt and Holmden, 2008). It is also necessary to discriminate between epeiric seaways (with shelf-like portions, shelf-breaks and even deeper distal parts; strongly directional currents) and epeiric embayments (lacking shelf breaks and ocean-type currents) (Brenner, 1980; see also Eriksson et al., 1998; 2008b). The former resembled extant open ocean shelves (Brenner, 1980) and can be compared to shallow oceans with some confidence, while the epeiric embayments were much smaller and shallower (Eriksson et al., 2004d; 2008b).

The reduced shelf gradients of many epeiric seas would have tilted the balance in favour of tides instead of storms (and thus also waves) (Eriksson et al., 2008b); on shallow water platforms, waves dissipate rapidly, while tidal height generally increases (Pratt and James, 1986). This supposition is supported by the presence of extensive peritidal flat deposits on the shoaling 
portions of several inferred epeiric sea basins of Phanerozoic age (Swett et al., 1971; Reading, 1978; Pratt and James, 1986; Friedman et al., 1992). Another characteristic of the Precambrian epeiric seas was profuse high energy braid-delta systems along their coastlines (Els, 1998; Eriksson et al., 2008b). Away from the river mouths where tidal interaction was important (e.g., Eriksson et al., 1995), wave-dominated coastline segments were possibly typified by amalgamation of supralittoral storm beds (Sarkar et al., 2004).

The development of the large scale and tide-dominated Precambrian epeiric embayments, with gentle gradients towards open oceans was commonly closely associated with large braided fluvial systems draining craton interiors and which flowed directly into these shallow seas (e.g., Eriksson et al., 2008b). High denudation rates under earlier Precambrian palaeo-atmospheric compositions also played a role in these systems (Els, 1998). In broad terms, preserved Precambrian shelf (cf., shelf-like epeiric) deposits are commonly sandy and they tend to resemble closely their Phanerozoic-Modern equivalents (Jackson et al., 1990; Lindsey and Gaylord, 1992; Eriksson et al., 1998) but with some significant exceptions (Sarkar et al., 2005, 2008; Catuneanu and Eriksson, 2007). Open shelf deposits dominated by wave imprinted nearshore sandstones and by massive and laminated mudstone with subordinate amounts of storm-deposited graded siltstone and fine grained sandstone, are spectacular in their preservation of fine primary features because of a lack of bioturbation (e.g., Schieber, 1989; Chakraborty and Bose, 1992; Sarkar et al., 2002a). Precambrian shoreface deposits, like their younger counterparts, are characterised by highly mature, well sorted sandstone (Walker and Plint, 1992), with virtually no mudstone, although pebbles and pebble lags may occur (Harris and Eriksson, 1990; Eriksson et al., 1998). Though hummocky and swaley cross-strata, parallel laminae, trough and planar cross-bedding are as common as in Phanerozoic successions (e.g., Soegaard and 
Eriksson, 1985; Bose et al., 1988; Jackson et al., 1990; Tirsgaard and Sønderholm,1997), Precambrian barrier island, wash-over fan (Eriksson, 1979) and lagoon deposits are only rarely discussed in the literature (e.g., Eriksson et al., 1998). However, tidal accentuation behind localized shoals has been recorded at places, such as in the Neoproterozoic Sonia Sandstone, India (Sarkar et al., 2008). The variation in sedimentation processes operating on Precambrian shelves (cf. epeiric seas) is elicited in the three examples discussed here, with the first two of Archaean and Palaeoproterozoic age highlighting considerable tidal influences and the third, of Neoproterozoic age, illustrating a dominant storm influence.

The c. 3.1-2.8 Ga Witwatersrand basin formed while composite terranes including greenstone belts were still accreting with the nucleus of the Kaapvaal craton (South Africa) and while widespread intrusion of granitoid rocks took place (De Wit et al., 1992; Robb and Meyer, 1995). As a result of accretion from north and west, the basin comprised a double (retroarc flexural) foreland depository, with the Witwatersrand Supergroup reflecting the foredeep and the partially correlated Pongola Supergroup the backbulge parts of a "greater Witwatersrand basin" (Catuneanu, 2001; Eriksson et al., 2009b) (Fig. 8). The weaker Kaapvaal continental lithosphere, inherent in the coeval evolution of both craton and supracrustal basin, allied to low angle subduction of the accreting terranes, gave a much shorter flexural wavelength, resulting in the forebulge remaining emergent throughout basin history (Catuneanu, 2004; Fig. 8). This emergent forebulge separated the foredeep and backbulge sub-basins, each characterized by a unique yet partly correlatable supergroup.

This greater Witwatersrand epeiric embayment can be traced for at least $400 \mathrm{~km}$ inland from the inferred craton margin and for at least $600 \mathrm{~km}$ along its inferred seaward margin (e.g., Eriksson et al., 1998). During an earlier phase of epeiric sedimentation, the c. 2970-2914 Ma 
(Robb and Meyer, 1995) West Rand Group (Witwatersrand Supergroup; foredeep) sub-basin collected up to $7.5 \mathrm{~km}$ of mudrocks, texturally mature sandstones and minor lavas, thought to have been deposited within shoreline to distal shelf palaeoenvironments subject to strong tidal influences (Eriksson et al., 1981; Burke et al., 1986; Stanistreet and McCarthy, 1991; Beukes, 1996). In the correlated Mozaan Group (Pongola Supergroup; backbulge) sub-basin, a combination of wave and storm-deposited sediments and subordinate fluvial braidplain sediments accumulated during this early phase (Beukes and Cairncross, 1991), under higher energy marine conditions due to a craton-marginal position (Fig. 8) (Eriksson et al., 2008b). A later phase of greater Witwatersrand basin sedimentation was restricted to the foredeep subbasin, where the $>2894$ - c. $2780 \mathrm{Ma}$ (Robb and Meyer, 1995) Central Rand Group, comprising mainly braided fluvial sandstones and subordinate auriferous conglomerates, was laid down. Large braided channel systems are thought to have flowed directly into the epeiric embayment due to a lack of vegetation, and large braid-deltas probably formed at the shorelines (Els and Mayer, 1993, 1998) where tidal reworking was important.

The c. 2.66- 2.05 Ga Transvaal Supergroup (Kaapvaal craton; preserved in three basins: Transvaal, Griqualand West, Kanye - Fig. 9) comprises four stratigraphic intervals: (1) a set of lowermost "protobasinal" (a descriptive term) immature fault-bounded basin-fills, present only in the Transvaal basin; (2) thin fluvial sheet sandstones of the Black Reef Formation (Transvaal and Kanye basins only); (3) a thick carbonate-BIF platform succession (c. 2642-2432 Ma Chuniespoort-Ghaap-Taupone Groups) across all three preserved basins; (4) a thick succession of clastic sedimentary and lesser volcanic rocks, belonging to the c. 2.4-2.1 Ga Pretoria Group (Transvaal and Kanye basins); a clastic succession overlying \#3 in the Griqualand West depository may be a correlate of the Pretoria, or might be approximately coeval with an 
estimated 80 my hiatus separating the chemical and clastic successions in the Transvaal basin (see discussion in Eriksson et al., 2001b; Catuneanu and Eriksson, 1999, 2002) (Fig. 10).

Three epeiric sea deposits are identified within the Transvaal succession. The first is that of the Chuniespoort-Ghaap-Taupone Groups (up to $2.5 \mathrm{~km}$ of stromatolitic carbonate rocks and 0.7 $\mathrm{km}$ of overlying BIF), interpreted to have formed within an epeiric seaway occupying a thermal sag basin which was at least $600,000 \mathrm{~km}^{2}$ in size (Beukes, 1987; Altermann and Siegfried, 1997; Eriksson and Altermann, 1998; Catuneanu and Eriksson, 1999). Within this basin, water depths are estimated to have been between 40 and $80 \mathrm{~m}$ for the carbonates and over $100 \mathrm{~m}$ for the BIF (Klein et al., 1987; Klein and Beukes, 1989). Within the succeeding Pretoria Group, two clastic epeiric embayment successions are inferred, for the Timeball Hill and for the SilvertonMagaliesberg formations (Fig. 10).

For the Timeball Hill embayment, preserved over an area of $\geq 500 \times 300 \mathrm{~km}$, rifting and subsequent thermal subsidence allowed advance of the sea onto the Kaapvaal craton (Catuneanu and Eriksson, 1999, 2002; Eriksson et al., 2001b). The preserved basin-fill (and its interpretation) comprises 5 facies associations: (1) basal carbonaceous mudrocks (anoxic suspension deposits); (2) grading up into sheets of laminated, graded mudrocks and (3) overlying sheets of laminated/cross-laminated siltstones and fine-grained sandstones (Te, $\mathrm{Td}$ and $\mathrm{Tc}$ subdivisions of low-density turbidity current systems; cf., Bouma, 1962; Lowe, 1982; Stow, 1986); (4) disconformably followed by sheets of mature cross-bedded sandstones (lower tidal flat), interbeded with lenses of immature sandstones and mudrocks (medial to upper tidal flat); (5) small lenses of coarse siltstone-very fine-grained sandstone (contourites; discussion in Eriksson et al., 2008b) occur within \#'s 1 to 3 and as local wedges at the \# $1-2$ facies association transition (Eriksson and Reczko, 1998). These genetic facies associations, the inferred tectonic 
setting, and thin stromatolitic carbonate interbeds within \#'s 1 to 3 (thereby suggesting photic water depths of c. $90-100 \mathrm{~m}$ in the absence of planktonic fossils), together suggest a relatively deep water embayment model (Fig. 11) for the Timeball Hill Formation sea (Eriksson and Reczko, 1998). It is postulated that as the Timeball Hill basin gradually filled with thick sheetlike delta-fed distal turbidite sediments, shallow water conditions followed, allowing progradation of uppermost sandy tidal flat deposits across the regressing basin, the latter fed by braid-deltas distal to proximal braided river systems advancing into the shrinking embayment from the west (Eriksson and Reczko, 1998; Eriksson et al., 2008b).

The younger Silverton-Magaliesberg clastic embayment is thought to have formed within a similar tectonic setting, and was of comparable dimensions to the Timeball Hill depository, but its inferred sedimentation systems were more akin to those of a modern passive margin-shelf setting (Eriksson et al., 2002, 2004d; 2008b). Up to $2 \mathrm{~km}$ of Silverton Formation basin-fill comprises thin basal braid-delta sandy deposits, overlain by a thick succession of argillaceous facies (inferred sub-storm wave base pelagic deposits in transitional and offshore mud belts) which were locally reworked by offshore storms (Eriksson et al., 2002; Fig. 11). These argillaceous deposits are interpreted as fluvial muds which bypassed a high energy coastal sand belt (the Magaliesberg Formation; Fig. 11) (Eriksson et al., 2002, 2008b). The latter formation reflects ephemeral braid-delta systems which provided clastic sediment to the high energy sandy peritidal flats characteristic of the Magaliesberg-Silverton embayment coastline (Eriksson et al., 1995). Detailed modeling of this palaeoenvironment by Parizot et al. (2005) suggests that braiddelta sediment supply exceeded tidal reworking capacity, thus promoting progradation of the Magaliesberg sandy deposits over the muddy-silty shelf-like deposits of the Silverton (Figs. 10 
and 11) (Catuneanu and Eriksson, 1999; Eriksson et al., 2001b). Comparing the two models in Fig. 11 shows a much lower inferred palaeoslope for the Silverton-Magaliesberg embayment.

Detailed studies of ripple marks and cyanobacterial mat features, extensively preserved within the Magaliesberg sandstones, indicate a paucity of high energy swash-formed ripples, limited wave heights (c. 1.5-23.5 cm; average $7 \mathrm{~cm}$ ), and shallow coastal water depths above tidal surfaces (c. 7-152 cm; average $31 \mathrm{~cm}$ ), with tidal conditions estimated to have been mesoto macrotidal (Eriksson et al., 1995; 2004d, 2008b; Parizot et al., 2005). A tide-dominated coastline lacking effective wave action is thus postulated, similar in many ways to coastal conditions inferred for the Witwatersrand epeiric foredeep discussed above.

The Neoproterozoic Sirbu Shale (Ray, 2006), Vindhyan Supergoup in central India (Fig. 1) has its basal $\sim 7.2 \mathrm{~m}$ constituted by mixed lithologies, both siliciclastic and carbonate, of lagoonal origin. The rest of the formation, up to $185 \mathrm{~m}$ thick, originated in a shelf setting through overall progradation following a transgression of the sea (Sarkar et al., 2002b). These authors identified six shelf facies, five of them maintaining gradational contacts between themselves and recurring in occurrence. The sixth facies is non-recurring, inordinately coarser and thicker than all other facies and has sharp lower and upper contacts. Wave-formed features are common to all facies. Among the first five facies, four are dominated by shale that encases sheets of well sorted siltstone or sandstone characterized by current structures at the sole, wave structures and overall grading within sheets, and with wave ripples on the tops in most cases. The fifth facies is sandstone with thinner interbedding of sandy siltstone. Current-formed sole structures, internal wave features, overall grading and bed-top ripples are present in this facies too, only larger in scale. All five facies were apparently deposited on a shelf dominated by seasonal storms. These five facies were genetically related, but differing in palaeogeographies, which varied from near 
storm wave base to above fair-weather wave base. The single occurrence of the incongruent sixth facies represents an extraordinarily strong wave-formed deposit, possibly induced by a seismic event.

The structures at the soles of the coarser grained beds of the first five facies often belong to multiple generations. Systematic generation-wise vector analysis of these structures reveals the operation of shore-parallel geostrophic flows, as documented in storm-affected modern seas (Walker, 1984; Niedorroda et al., 1985). It is apparent that geostrophic flow increasingly dominated over offshore directed flow with the passing of the peak storm stage and with increasing distance from the shore (Chakraborty, 2002; Sarkar et al., 2002b).

\subsection{Deltaic systems}

Deltas in the Precambrian, both Archaean and Proterozoic, are well documented, but it is not easy to distinguish their constituent subenvironments. The distinction between ideally channelized and fining-upward delta plain deposits, and non-channelized and coarsening-upward progradational delta front deposits is often too subtle to pin-point in non-fossiliferous Precambrian successions. The difficulty in discriminating subenvironments thus stems mainly from the poorly preserved evidence of biogenic activity extant in Precambrian time. General similarity in terms of facies associations, sedimentary structures (non-biogenic) and lithological distributions, nevertheless, indicates general similarity in terms of depositional environments and processes between deltas of Precambrian and Phanerozoic times (e.g., overview in Eriksson et al., 1998). Thus, Precambrian deltaic sequences are characterized by the same overall coarsening-upward vertical profiles as observed in Phanerozoic-modern deltas, showing a 
transition from the muddier facies of the prodelta into the sandier facies of the delta front and distributary mouth bar subenvironments, conformably or unconformably overlain by the delta plain facies. Distributary channels on Precambrian delta plains presumably had poorly consolidated banks and consequently had a preference for braiding in consistency with the general consensus for Precambrian rivers in this regard (Schumm, 1968; Long, 2004). Their deposits exhibit the most diverse lateral facies variation and include a variety of sedimentary structures corresponding to different flow regimes, conspicuous erosional surfaces and wide palaeocurrent variations. Precambrian delta front sediments, on the other hand, show an overall similarity but with localised gravity-flow products and soft-sediment deformation structures. The prodelta facies also include frequent deformational structures, such as convolute bedding, diapiric features and loading structures. The presence of such deformational features attests to higher slope of the depositional palaeosurface and high sedimentation rates. Conglomerates, as channel lag deposits, are quite common at the base of the tidal channels or distributary channelfills. Petrographically, the sandstones are somewhat immature and can be characterized as quartz arenites and subarkoses with lithoclasts such as chert fragments. One major difference between the Precambrian and Phanerozoic delta system lies in the stupendous thickness of stacked deltaic lobes. For example, the Basnaering delta complex of northern Norway has a maximum thickness of $3500 \mathrm{~m}$, and thickness of the delta front - mouth bar - delta plain succession exceeds $400 \mathrm{~m}$ (Siedlecka et al., 1989); thickness of the delta front - mouth bar - delta plain succession in the Archaean Moodies Group, South Africa, similarly exceeds 400 m (Eriksson, 1979). The other significant difference is in comparative textural immaturity of the Precambrian deposits. These two differences can be accounted for by the high subsidence rates, steep topographic slopes and sharp reliefs of a tectonically active rift-related basin, very much characteristic of the 
Precambrian depositories (Eriksson et al., 1998). A high rate of sediment supply under efficient alluvial transportation in pre-vegetational time could also have facilitated acquisition of huge thicknesses (Eriksson et al., 1998).

The marginal marine environment was also characterized by the more common presence of braid-delta systems during the Precambrian than in Phanerozoic time (Nemec and Steel, 1988). Braid-delta deposits tend to show both fluvial and wave/tide influences, reflecting complex modification of alluvial deposits in the shore zone. In Precambrian time, rapid chemical weathering (Corcoran et al., 1998; Donaldson and de Kemp, 1998) and intense erosion in the absence of vegetation promoted the development of large braided river systems characterized by high discharge rates. Such braided river systems debouching directly into gently sloping marine shelves of Precambrian epeiric seas, commonly produced extensive braid-deltas (Els, 1998).

\subsection{Lacustrine systems}

Lacustrine deposits, whether Precambrian or Phanerozoic, can be explained as analogous to products of small-scale ocean margins, with less intense wave processes (Galloway and Hobday, 1983). Except for significant lunar tides and marine swells, wind-induced waves in lakes are almost the same as in seas (Friedman et al., 1992). Hence the distinction clearly lies in the magnitude of the wave-action simulating the processes of open marine microtidal coasts (Galloway and Hobday, 1983). In the Phanerozoic record, lake deposits can easily be identified by palaeontological studies, supported further by travertine, tufa, trona and magadiite (a sodiumsilicate mineral) occurrences (e.g., Reeves, 1968; Hardie et al., 1978; Hallam, 1981; Eugster, 1986; Ordonez et al., 1991). In contrast, Precambrian lake deposits are hard to identify chiefly 
due to the absence of preserved palaeontological evidence. Furthermore, evaporites of Precambrian time are generally represented by pseudomorphs, which do not point to any certain origin (Donnelly and Crick, 1988). The common cyclicity of lake deposits, reflecting climatic variability, is also analogous to many marine mesosequences (Friedman et al., 1992), and stromatolites tend to be common in both environments (Hallam, 1981). The discrimination of Precambrian lacustrine deposits from shallow marine and epeiric sediments is thus subtle and problematic (Hallam, 1981; Miall, 1984; Montes et al., 1985; Winston, 1986; Donnelly and Crick, 1988; Schieber, 1998; Eriksson et al., 1998).

\subsection{Microbial mat influence on clastic sedimentation}

One of the most spectacular and unique features of the Precambrian, particularly the Proterozoic siliciclastic depositional systems, was the prolific growth of microbial mats on almost all wet sediment surfaces within the photic zone. In the absence of grazers and burrowers there were few environmental barriers to microbial mat growth and in the absence of plankton, light penetration extended the photic zone deeper in Precambrian seas or lakes (Walter and Heys, 1985). Microbiota appeared on earth before $3.8 \mathrm{Ga}$, and likely proliferated and flourished on most damp sediment surfaces during Proterozoic time (Schopf, 1999; Hagadorn and Bottjer, 1999; Eriksson et al., 2000; Schieber, 2007). The documented siliciclastic microbial mat record extends back $2.9 \mathrm{Ga}$ (Noffke et al., 2006). While stromatolites and microbial laminites abound in Precambrian carbonates, mat features in their siliciclastic counterparts are far more subtle and provide challenges in their recognition. Although laboratory experiment suggests microbial mat growth needs several weeks of non-burial (Gerdes and Klenke, 2003, 2007), thin mat does 
develop on siliciclastic beaches or tidal flats within ebb intervals of 8 to 12 hours (Eriksson et al., 2009a).

Microbial mats are tough leathery clusters of micro-organisms embedded in extracellular polymeric substances (EPS) that stabilise clastic sediment surfaces (Schieber et al., 2007). The cohesiveness imparted to the sediment grains reduces erodibility of sediment, even that of granular sand (Schieber, 1998, 1999, 2004; Gehling, 1999; Pflüger, 1999; Gerdes et al., 2000; Noffke et al., 2001, 2002, 2003; Sarkar et al., 2004, 2005, 2006, 2008). A relatively high degree of preservation of bedforms, including those with little preservation potential, is thus a distinctive feature of shallow marine Proterozoic siliciclastic formations (Sarkar et al., 2008). More significant distinction between Proterozoic and Phanerozoic siliciclastic formations, in terms of sequence-building, is also likely to arise from this mat-induced reduced erodibility of sediment. Consequent reduction of sediment budget and the low gradient of epeiric sea floors of the Proterozoic could have encouraged vertical stacking of highstand systems tracts, restricting the intervening records of transgressions merely to transgressive lags (Sarkar et al., 2005, 2008; Catuneanu and Eriksson, 2007).

Depending on the role microbial mats played in their formation, the resultant sedimentary structures can be grouped into three categories:

1) Mat layer or mat ground: structures that represent the extensive mat grounds themselves, either preserved intact or deformed;

2) Mat-induced: structures that owe their origin to microbial mats; without presence of mats they are not expected to form in the first place;

3) Mat-protected: for these structures microbial mat is necessary not for generation but for preservation. In other words, the formative process of these structures is not 
dependent on microbial mat growth, but being too delicate, their preservation needs stabilization, either through microbial mat growth or by cementation that is generally delayed in siliciclastics (Sarkar et al., 2008).

A genetic classification of mat-related structures would perceivably be more meaningful, notwithstanding the fact that similar features often draw diverse genetic interpretations. Among the three main genetic schemes in existence, Gerdes et al. (2000) on the basis of their work on modern siliciclastic coastlines recognise six genetic factors: (i) intrinsic biofactors; (ii) biological response to physical disturbances; (iii) trapping and binding of detritus; (iv) mechanical deformation of biologically stabilized sediment surface; (v) post-burial process; (vi) bioturbation. Maintaining the same approach, but fitting them into the list of primary (physical) sedimentary structures of Pettijohn and Potter (1964), Noffke et al. (2001) grouped microbial mat-induced structures (MISS) into two classes, (A) on bedding planes, and (B) within beds; both are divided into several subclasses:

Class A:
a) levelled depositional;
b) microbial mat chips;
c) erosional remnants and pockets;
d) multidirectional or palimpsest ripples;
e) mat curls and shrinkage cracks.

Class B:

a) sponge pore fabrics, gas domes, fenestrae structures;

b) sinoidal laminae;

c) oriented grains, benthic ooids; 
d) biolaminites, mat-layer-bound grain sizes.

In a more insightful genetic scheme, Schieber (2004) classified microbial mat-related structures on the basis of the processes involved, such as growth, metabolism, destruction, decay, and diagenesis. His scheme appreciates the difference in the nature of proxy records of past proliferation of microbial mats between sandstones and mudstones (Schieber et al., 2007). A glimpse into the spectrum of Precambrian microbial mat-related structures in sandstones and mudstones is exemplified by the Neoproterozoic Sonia Sandstone, belonging to the Jodhpur Group of the Marwar Supergroup, western India, and by the Palaeo- to Neoproterozoic Vindhyan shales in central India (Fig. 1).

Microbial mat-related structures in sandstone are exemplified here from the Neoproterozoic Sonia Sandstone to immediate north of Jodhpur City, Rajasthan (Fig. 1B) not only because the array is wide, but also because it includes rare examples of mat ground preserved intact (Fig. 12). The Sonia Sandstone Formation, almost entirely arenitic, rests on a rhyolitic basement (Pareek, 1984; Chauhan, 1999; Sarkar et al., 2005, 2008). U-Pb dates for the youngest detrital zircon population of the Jodhpur Group which includes the Sonia Sandstone at its base, fixes the maximum age of the Formation at c. 800 Ma (Malone et al., 2008). The 150m thick Sonia Sandstone is topped by an unconformity, and all the mat-related structures described so far from it, occur within its uppermost 60m thick coastal marine interval (Chauhan, 1999; Chauhan and Ram, 1999; Sarkar et al., 2005, 2008).

Reddish iron-encrusted veneers on bed surfaces that incorporate platy minerals in random or imbricated orientation, and occasional pyrite enrichment in subjacent carbonaceous laminae, support past proliferation of microbial mats (Fig. 13). The pyrite may point to anoxic conditions developed beneath the inferred mats by sulphur-reducing bacteria (Sarkar et al., 2008 and 
references therein). The mat grounds include many features: some disc-like forms with nonerosional bases and corrugated tops, marked by radiating chains of spindles, as if stromatolites grew horizontally (Fig. 12). Extensive mat grounds also include: crumpled sheets bearing minute drag folds (Fig. 14), and wrinkle structures (cf., Hagadorn and Bottjer, 1997; Sarkar et al., 2008). The observed variation in mat-related structures is widest for the mat-induced category, and the most common elements within this category are cracks and ridges in varied patterns and in varied relationships with primary, physically-formed structures. Considering the well sorted nature of the sandstone, the cracks evince unexpected cohesiveness that is most readily attributable to the EPS associated with microbial mats (cf., Parizot et al., 2005; Pflüger and Greese, 1996). The variation also includes small bulges possibly reflecting trapping of fluid underneath the mats, and small craters surrounded by radiating cracks, inferred to have been created by fluid piercing through the mats (cf., Gerdes et al., 1993; Pflüger, 1999; Sarkar et al., 2004, 2006, 2008). The mat-protected category includes setulfs (Friedman and Sanders, 1974; Bottjer and Hagadorn, 2007; Sarkar et al., 2008), patchy (Noffke et al., 2001; Bouougri and Porada, 2002; Sarkar et al., 2004, 2008) and mat-protected ripples (Sarkar et al., 2006, 2008), preserved intact despite being subjected to subsequent reworking by high energy flows.

Microbial mats in the Sonia Sandstone did not remain confined to high littoral-supralittoral palaeoenvironments like most of their modern counterparts, but also extended to the shallow neritic zone. Some of the mat-related structures show a palaeoenvironmental preference in occurrence (Fig. 2). For example, mat grounds retaining intact primary growth structures show distinct preference for the transition between the high littoral and supralittoral palaeoenvironments. It is possible that beach rock formation helped their retention. In contrast, wrinkle structure shows little palaeoenvironmental preference, although Banerjee and 
Jeevankumar (2005) described the occurrence of wrinkle structures exclusively from a neritic palaeoenvironment within the Palaeoproterozoic Koldaha Shale, central India. The only example of crumpled sheets in the Sonia Sandstone, however, belongs to the high littoral palaeoenvironment; strong flow shear presumably created the drag folds. Bulges, mat-protected ripples and patchy ripples are straddled across the high littoral and supralittoral palaeoenvironmental transition. Mat-protected setulfs were found in numbers, but exclusively within sedimentary rocks ascribed to the low supralittoral palaeoenvironment. Cracks and ridges, apparently polygenetic, are distributed almost all through the studied marine succession.

Microbial mat features are comparatively more subtle in shales because of the more compactible nature of the sediment (Schieber, 2007) and examples have been drawn here from two shales, viz. the Rampur Shale and the Bijoygarh Shale, belonging to the Vindhyan Supergroup, exposed around Rampur and Amjhor (Fig. 1; Schieber et al., 2007). The former shale was deposited at the beginning of the Mesoproterozoic period, and the latter at the early part of the Neoproterozoic in a deep offshore setting where sedimentation had been episodic. Both the shales are generally dark in colour, but are striped with shade variations and have significantly elevated organic carbon contents. The most conspicuous feature in them is carbonaceous laminae whose wavy-crinkly nature relates them to microbial mats and distinguishes them from planar laminae in non-mat carbonaceous shales. Swarms of the wavycrinkly carbonaceous laminae characteristically give rise to an anastomosing pattern; individually they may have frayed edges and together they may give rise to false cross-strata. Another significant feature is abundant occurrence of minute shale fragments that are readily outlined in lamina-parallel polished sections and bed-normal thin sections. Some of the fragments bear disparately coarser detrital particles evincing rafting by mat fragments (cf., 
Fagerstrom, 1967; Olsen et al., 1978; Schieber, 1999). Some carbonaceous laminae in the Bijoygarh Shale reveal early diagenetic pyrite concentrations in an anastomosing pattern that are readily attributable to mat decay. In the same association there are clusters of phosphatic spheroids that fill in and accrete around spherical structures of a few microns diameter. These spheroids resemble those reported from the Neoproterozoic of China that apparently formed by phosphate precipitation on bacterial cell walls (Xiao and Knoll, 1999).

Widespread microbial mat growth on Precambrian sediment surfaces, whether carbonate or siliciclastic, is widely accepted (e.g., Schieber et al., 2007; Sarkar et al., 2008). Lack of bioagronomy must thus have led to general intrastratal preservation of organic carbon. Shallow water sediments of Precambrian age, both carbonates and siliciclastics, therefore had a hydrocarbon source potential almost as good as that of deep water anoxic sediments. Prolific growth of microbial mats required a slow rate of net sedimentation, and widespread epeiric seas during the Proterozoic had been especially conducive to such conditions. Development of transgressive systems tracts was in consequence severely impaired and vertical stacking of highstand systems tracts may have been preferred in consequence (Sarkar et al., 2005; Catuneanu and Eriksson, 2007).

\section{Carbonate depositional systems}

\subsection{Introduction}

Carbonates have been a feature of the sedimentary record since early Archaean times, and have been associated typically with microbialites and allochems such as stromatoclasts, ooids 
and peloids. Carbonates became increasingly widespread and abundant through the Neoarchaean and into the Palaeoproterozoic, through the Mesoproterozoic and peaked in the Neoproterozoic, followed by a sharp decline of dolostone through the Phanerozoic (Fig. 15), when limestone continued to increase due to the rise of shelly faunas. The dominant mineralogy of carbonates has thus changed over time, from early Archaean iron-rich dolomites, to well-ordered true dolomites from the Neoarchaean through to the Mesoproterozoic, with gradually increasing proportions of limestone throughout that time.

An overwhelming preponderance of abiological silica deposition over carbonate rocks existed from the Archaean until the mid-Mesoproterozoic, but declined thereafter and became insignificant by the Neoproterozoic (Fig. 15). Most explanations for this involve the geotectonic setting of deposits within active plate margins (greenstone belts), which led to prevalence of hydrothermal, silica-rich fluids and to deposition of cherts. In contrast, the carbonates are usually interpreted as passive plate margin deposits, and here silica domination led to syn- and postdepositional silicification of clastic and carbonate sediments, often with relict minerals and replacement structures of former carbonates (Lowe, 1999). However Palaeoproterozoic cherts associated with iron formations (e.g., the $1.88 \mathrm{Ga}$ Gunflint Formation, northwestern Lake Superior region) often appear to have formed largely by direct silica precipitation at or just below the seabed, and lack ghosts or inclusions of carbonate precursors. They may provide evidence that global oceanic silica concentrations were higher during the Palaeoproterozoic era than at later times. In Mesoproterozoic and Neoproterozoic strata, early diagenetic silicification was largely restricted to peritidal environments, with cherts typically occurring as nodules or discontinuous beds within carbonate deposits that have similar depositional textures. These cherts formed primarily by carbonate replacement with subsidiary primary silica precipitation 
(Maliva et al., 2005). Younger Precambrian active plate margin sedimentary rocks do not display such a dominance of chert, supposedly because of lower geothermal gradients and weaker hydrothermal activity. Another factor however was the high proportion of $\mathrm{CO}_{2}$ in the earlier Precambrian atmosphere. This would have produced acidic oceans, favouring silica precipitation; carbonates would have been precipitated only where alkalinity was raised, e.g. in the ambient waters mediated by the metabolic processes of microbialite-building benthic microbial communities. The pattern of carbonate abundance was mirrored to a large extent by an increase in stromatolite diversity through most of the Precambrian (cf., Riding, 2006; Awramik and Sprinkle, 1999), perhaps revealing an early, strong microbial link with carbonate precipitation.

The main locus of carbonate precipitation in the Early Archaean was in association with hydrothermal systems (e.g., the 3.5 Ga Dresser Formation of the Warrawoona Group, Western Australia). A sudden rise in carbonate accumulation at $3.0 \mathrm{Ga}$ could have involved the emergence of cyanobacteria able to calcify and to construct stromatolitic reefs in varying environments (Altermann et al., 2006). The oldest preserved stromatolitic carbonate platform is the 3.0 Ga White Mfolozi Formation of the Pongola Supergroup of South Africa (Altermann et al., 2006). It has been argued that the emergence of stable continental shelves permitted the accumulation of thick carbonate deposits over time (Grotzinger, 1989, 1994). By the Neoarchaean, thick shallow-water shelfal sequences were deposited on a number of cratons (e.g., Fennoscandian, Superior, Kaapvaal, São Francisco, Amazon, Zimbabwe, Dharwar and Congo). Carbonate platforms in which most of the essential Phanerozoic features can be recognized were well developed by the Neoarchaean/Palaeoproterozoic, including ramps and rimmed shelves (e.g., Grotzinger, 1989). The Archaean-Proterozoic boundary represents a major episodic change in the growth of the continental crust - and also a jump in the number of stromatolite taxa 
(Awramik and Sprinkle, 1999). The appearance of widespread, kilometres-thick, stromatolitic carbonate platforms such as the exceptionally well preserved 2650-2500 Ma CampbellrandMalmani platform of Kaapvaal, South Africa, and the mechanisms of biocalcification and carbonate precipitation are highly debated, and are discussed below.

In the Precambrian, stromatolites accreted in basinal to shallow subtidal and supratidal environments, but it is in reefs (or biostromes) that they achieved their greatest morphological diversity, with a wide range of growth forms, including branched, columnar, domal and planar, often interbedded with oolites, peloids and intraformational breccias. The number of recognized columnar stromatolite forms rises to a maximum in the Mesoproterozoic, before dropping sharply in the Neoproterozoic, with relatively few in the Cambrian (e.g., Tucker et al., 1990). An interplay of biological and environmental factors produced widespread, diverse and abundant forms that have varied over time, with particular forms restricted to certain time intervals. As such, they have been used for stratigraphic purposes, though the environmental control on morphology renders a binomial taxonomy untenable; instead microstructural variation has been used to apply biostratigraphic markers, though with similar constraints. However, stromatolites can be used with some confidence as environmental indicators (e.g., Altermann, 2008).

Despite their abundance, mechanisms of non-skeletal carbonate precipitation are poorly understood. The contrast between carbonate platforms dominated by microbialitic deposits in the Precambrian and those dominated by algal and invertebrate remains in the Phanerozoic records a significant change in the major processes of carbonate production and sediment accumulation. However, many questions remain: (1) were Precambrian carbonates largely mediated by microbial metabolic processes?; (2) are Precambrian stromatolites witnesses to the early evolution of life, preserving fossil microbial remains as old as $\sim 3.5 \mathrm{Ga}$ ?; (3) or might they simply 
have been chemical precipitates from carbonate oversaturated oceans?; (4) do modern stromatolites provide a process analogue for carbonate precipitation in the Precambrian? Detailed field-based studies of ancient carbonates from around the world provide some answers, as detailed in the next section.

\subsection{Carbonates: genetic patterns through early Precambrian time}

In the Early Archaean, marine carbonates were deposited as minor components of greenstone belts during periods of local tectonic stability. Although relatively scarce, these rocks are important because they record chemical and isotopic informaton about the composition of contemporary oceans. The earliest examples date from $\sim 3.5 \mathrm{Ga}$ and include the $\sim 3.5 \mathrm{Ga}$ Warrawoona Group of the Pilbara region, Western Australia, and the 23.3 Ga Barberton Greeenstone Belt of the Swaziland Supergroup of South Africa, with stromatolites present in both. The Barberton stromatolites (Byerly et al., 1986), which are developed in thin cherty units interbedded with komatiitic lavas in the uppermost part of the Onverwacht Group, and stromatolites of the Warrawoona Group, both feature small, domal forms. Massive black and banded carbonaceous cherts, and carbonaceous laminites, are also common in early Archaean greenstone belt volcanic sequences.

The 3.5 Ga Dresser Formation is part of the mostly volcanic Warrawoona Group in the North Pole Dome area of the Pilbara craton. It comprises interbedded chert and baryte units, carbonates and pillow basalt. Silicified during the late Eocene to Oligocene, the surface outcrops of layered chert actually represent the altered equivalents of bedded carbonate rocks at depth (van Kranendonk et al., 2006). The carbonates, primarily ferroan dolomites, were deposited both 
within a volcanic caldera that was dominated by hydrothermal processes and continued into shallow water and intermittently exposed conditions with bedded carbonates, often with ripple forms (Fig. 16) where stromatolites flourished. These include coniform, domical and stratiform varieties with wrinkly laminations. At the North Pole locality, wrinkly stratiform stromatolites pass laterally into smooth domical forms (Fig. 17). Black- and red-weathering surface outcrops of wrinkly stromatolitic laminates are the surface-altered equivalents of laminated pyrite at depth, as seen in fresh drillcore: textural evidence shows that the pyrite replaced sedimentary carbonate (van Kranendonk et al., 2008). Ueno et al. (2008) found quadruple sulphur isotope evidence for sulphate reducing bacteria (SRB) in cherts of the Dresser Formation.

The 3.43 Ga Strelley Pool Chert (SPC) is widespread in the upper part of the Warrawoona Group and ranges from 15 to $30 \mathrm{~m}$ in thickness. It consists of grey or white, iron-rich, dolomitic carbonate or silicified carbonate interbedded with units of quartz, possibly after barite, with primary chert units. The carbonates can be traced laterally into the silicified intervals providing clear evidence of replacement. The carbonate and silicified carbonate intervals are generally laminated. Stromatolitic structures are found at well defined intervals of 1-2 m thickness in carbonate and silicified carbonates lower in the formation.

A different stromatolite morphology is developed in the SPC, where small crested domes and conical stromatolites are typical. At the Shaw River (Trendall locality), stromatolites comprise coniform columns and bumps ('egg-boxes') in stratiform, generally isopachous stromatolitic layers, deposited under shallow, low-energy, subaqueous conditions, with occasional evidence of erosion around the base of some steeper domes. The angular, coniform structures at the Trendall locality show greater uniformity of laminae when compared with inter-stromatolite areas, indicating that the latter were subjected to more variable depositional conditions. Steep-sided 
cones show slopes that are higher than the angle of sediment repose, while tracing the structures along strike shows that they grade into domal and undulatory forms with irregular spacings, both vertically and laterally, arguing against slumping or lateral compression as a cause. Undulatory, domical and coniform laminae often show considerable vertical continuity (Fig. 18) within specific horizons, indicating irregular growth consistent with competitive growth under slightly varying environmental and biochemical conditions. These combined factors favour a biogenic rather than a physico-chemical origin, although the biogenicity of Archaean stromatolites has been challenged in favour of a hydrothermal or diagenetic origin (e.g., Lowe, 1994; Grotzinger and Rothmans, 1996; Brasier et al., 2004).

Allwood et al. (2006) investigated stromatolite morphologies in the SPC in the context of their palaeoenvironmental setting, across more than $10 \mathrm{~km}$ of relatively continuous outcrop where the formation is best preserved. They argued that the SPC can best be interpreted as a fossil microbial carbonate platform based on a number of criteria: the inferred palaeoenvironmental setting, the combined attributes of the stromatolites, stromatolite distribution within the palaeoenvironment, and their similarity to younger, microbially mediated peritidal carbonates. They undertook the first morphotype-specific analysis of the structures within their palaeoenvironment and refute abiogenic hypotheses for their formation, arguing that the diversity, complexity and environmental associations of the stromatolites describe patterns that compare with similar settings throughout Earth's history that reflect the presence of organisms.

Partially silicified dolomitic stromatolites occur in the $\sim 3.0$ Ga White Mfolozi section of the Pongola Supergroup, South Africa. Composite columnar stromatolitic bioherms 0.7 - $1.6 \mathrm{~m}$ high and $0.4-1.0 \mathrm{~m}$ in diameter formed along the margins of a tidal channel, with flat stratiform and 
small domical stromatolites growing in low energy tidal flat environments (Altermann, 2008). Conical stromatolites accreted in high-energy, coarse-grained carbonate sand along the bottom of the tidal channel, and have been linked to the activities of filamentous, oxygen-producing, photoautotrophic cyanobacteria (e.g., Beukes and Lowe, 2006).

Greenstones containing carbonates at $\sim 2.8$ Ga include the Abitibi, Yellowknife, Wabigoon (Steep Rock Lake), Michipicoten and Uchi belts of Canada and the "Upper Greenstones" of Zimbabwe. The Zimbabwean Belingwe Greenstone Belt, 2.7 Ga, is one of the best preserved and least deformed of all Archaean greenstone successions. Carbon and sulphur stable isotope data from Belingwe stromatolitic carbonates indicate that rubisco-based oxygenic photosynthesis was operating by at least $2.7 \mathrm{Ga}$, while data from shales indicate a strong methanogenic signal (Grassineau et al., 2002).

The $\sim 2.8$ Ga Steep Rock Group of northwest Ontario is one of the world's thickest Archaean carbonate platform successions (Kusky and Hudleston, 1999). Deposited unconformably over the Marmion Complex, a 3001-2928 Ma gneissic terrane, it comprises biogenic and oolitic limestones, dolostones, micrites, and karst breccias capped by a thick palaeosol developed between and over karst towers. The presence of aragonite fans, herringbone calcite, and rare gypsum molds points to the carbonate platform having experienced hypersaline depositional conditions, and suggests that solid sulphates were able to form, possibly replaced by carbonate on a large scale (Gandin et al., 2005; Gandin and Wright, 2007).

Stromatolites of the $\sim 2.7$ Ga Beechy Lake Group of the Yellowknife Supergroup form lenses within volcanic breccias at the margins of felsic domes. Bioherms of low, wavy-laminated dolomitic mounds up to $2 \mathrm{~m}$ thick extend laterally for hundreds of metres, characteristically forming thin encrustations on breccia blocks. These units typically contain millimetre-scale 
layers of fine volcanic ash at regular intervals, testifying to periodic explosive eruptions during the development of isolated microbial communities around areas of fumarolic (or hydrothermal) activity near active volcanic domes along the shallow flanks of an emergent stratovolcano (Lambert, 1998).

The Archaean Kaapvaal craton, one of the best-preserved, includes the CampbellrandMalmani platformal carbonates, which persisted for some $80 \mathrm{my}$, from $2588 \pm 6 \mathrm{Ma}$ to at least $2516 \pm 4 \mathrm{Ma}$ (Altermann and Nelson, 1998). Similarly extensive and well-preserved is the 2.6 to 2.5 Ga old Carrawine Formation of the Pilbara craton (Nelson et al., 1999). The deposition of the Campbellrand Subgroup occurred on a shallow marine platform, and comprises basinal nonstromatolitic, laminated carbonate and shale with minor chert, iron formation and mafic tuff beds, with abundant shallow water stromatolitic carbonates, some of which may be replacive after evaporites (Gandin et al., 2005; Gandin and Wright, 2007).

3.3. Relationships between carbonate rocks, carbonate mineralogy, seawater chemistry, microbial mediation and physico-chemical precipitation

The significant differences between Precambrian and Phanerozoic carbonates have been attributed in large part to 'controlled biomineralization' which was either unknown or uncommon prior to the Phanerozoic (e.g., Lowenstam, 1981; Wright and Oren, 2005). Precambrian carbonates generally comprise a range of microbialites, particularly stromatolites with other facies, such as oolitic and peloidal grainstones, and although conventional interpretations link their genesis to chemical precipitation directly from seawater, their abundance and diversity together with the lack of unequivocal evidence for large-scale marine 
carbonate precipitation raises the question of a genetic association between carbonates and microbially-mediated processes. In particular, the widespread belief that "with higher carbon dioxide levels, Precambrian seawater was more supersaturated with respect to $\mathrm{CaCO}_{3}$ than Phanerozoic seawater and carbonates were precipitated easily" (e.g., Tucker, 1992) does not fit with the observation that higher $\mathrm{CO}_{2}$ levels increase ocean acidity and make it more difficult for some organisms to secrete calcium carbonate. Similarly, speculation that warming of the oceans and enhanced biological uptake at that time drew down oceanic $\mathrm{CO}_{2}$ so that alkalinity levels in the ocean were sufficient to counteract dissolution (Karhu and Holland, 1996) conflict with observations that increased $\mathrm{CO}_{2}$ leads to lower $\mathrm{pH}$ and therefore an increase in oceanic acidity that inhibits $\mathrm{CaCO}_{3}$ precipitation (e.g., Andersson et al., 2003; Wright and Oren, 2005).

Seawater saturation state is often cited as the principal factor determining carbonate precipitation during the Precambrian (e.g., Grotzinger, 1994; Sumner, 1997; Sumner and Grotzinger, 2000). In modern oceans, the minimum thermodynamical requirement for calcite to precipitate is exceeded by a factor of almost 5 ( $>3$ for aragonite) (Ridgewell and Zeebe, 2005). Yet despite supersaturation of surface sea water with calcite, aragonite and dolomite, spontaneous inorganic precipitation of these phases from sea water does not normally follow (e.g., Leeder, 1982; Wright, 2000; Morse et al., 2003; Wright and Oren, 2005), while experiments have shown that homogeneous nucleation does not occur in sea water solutions until saturation levels of calcite reach $>\sim 20$ - 25 (Morse and He, 1993).

However, these are not the only factors operating: kinetic factors can strongly affect the behaviour of ions in saline solution, including the formation of ion pairs or complexes, and hydration shells (e.g., Slaughter and Hill, 1991; Wright and Oren, 2005). In saline solutions, ion pairs form due to short-range interactions of adjacent ions, attracted by coulombic forces. This 
complexing reduces the ions' activities below their modalities, making precipitation of carbonate minerals unlikely. For example more than $90 \%$ of total $\mathrm{CO}_{3}{ }^{2-}$ is complexed with hydrated metal cations, chiefly magnesium (Garrels and Christ, 1965; Wright, 2000; Wright and Oren, 2005). The presence of other ions in solution thus shields $\mathrm{Ca}^{2+}$ and $\mathrm{CO}_{3}{ }^{2-}$ ions from interacting and precipitating.

Although carbonate precipitation occurs as cements and coatings in the modern marine environment, it is primarily under direct metabolic control, associated with the activities of metazoa. No microbes have been found to be "obligate calcifiers" (Riding, 1982; Riding and Liang, 2005). So we should ask: in the absence of metazoans, how can the kinetic inhibitors to marine carbonate production be overcome? There is abundant evidence that these kinetic inhibitors can be overcome on a large scale through microbial mediation (e.g., Nadson, 1928; Slaughter and Hill, 1991; Robbins and Blackwelder, 1992; Robbins et al., 1996; Warthmann et al., 2000; Wright, 2000; Wright and Altermann, 2000; Wright and Wacey, 2004, 2005; Wright and Oren, 2005). Numerous different bacterial species have previously been detected and assumed to be associated with natural carbonate precipitates from diverse environments. The primary role of bacteria in the precipitation process has subsequently been ascribed to their ability to create an alkaline environment (high $\mathrm{pH}$ and [DIC] increase) through various metabolic processes (Castanier et al., 1999; Douglas and Beveridge, 1998).

Late Archaean and Palaeoproterozoic strata are suggested to record extreme marine supersaturation maintained by the inhibiting effect of $\mathrm{Fe}^{2+}$ on calcite nucleation and growth (Sumner and Grotzinger, 1996), leading to the "in situ" precipitation of widespread aragonite botryoids and crystal "fans" as well as calcite (Sumner and Grotzinger, 2000). But these aragonite botryoids and crystal fans, up to $50 \mathrm{~cm}$ tall in the $\sim 2.6 \mathrm{Ga}$ Campbellrand-Malmani 
carbonates of the Transvaal basin of South Africa, accreted while expanding upwards from (carbonate) bedding surfaces and stromatolites - if this was an inorganic process unassociated with microbial processes, why did these aragonite deposits not appear on the surfaces of different facies and lithologies? Why do the observed features occur only in carbonate? Similarly, Simonson et al. (1993) considered that crystal fans in the coeval carbonates of the Carawine Dolomite of the Hamersley Basin, Australia, once possibly joined with the Transvaal basin, were originally aragonite, but found it "worrisome" that the crystal morphologies lacked the "distinctive square-tipped terminations" of radiating aragonite crystals.

Hardie (2003) and Gandin et al. (2005) have argued convincingly that the fans (Fig. 19) were not originally aragonite, but gypsum. Gypsum domes of the Upper Miocene Solfifera Series of Sicily (Hardie and Eugster, 1971), are "astonishingly similar" to the crystal fans, indicating that a sulphate precursor is entirely possible (Hardie, 2003). In the Gamaohaan Formation of South Africa, certain features and textures, including carbonate fans and "herringbone calcite", indicate the former presence of evaporites, now replaced by carbonate, and that these evaporites were thick at times and also occurred at particular, laterally extensive horizons. Gandin et al. (2005) and Gandin and Wright (2007) argue that calcitization of the vanished but once laterallyextensive evaporites was driven by bacterial sulphate reduction of solid sulphate in association with organic diagenesis and pyrite precipitation within platform-wide microbialites and sapropels. Large-scale microbial mediation of ambient waters across a shallow to emergent platform is thought to have raised carbonate alkalinity and removed kinetic inhibitors to carbonate formation.

Shallow-water and sabkha evaporites previously formed in settings much larger than any found today, in vast expanses of evaporitic lagoons and mudflats reaching $>100,000$ 's $\mathrm{km}^{2}$ in 
extent, over which brine depths were at most a few metres. Examples include the $90 \mathrm{~m}$ thick Lower Cretaceous Ferry Lake Anhydrite deposited in a shallow lagoon $260 \mathrm{~km}$ wide (Loucks and Longman, 1982), and the 100 m thick, Permian San Andres Formation (Palo Duro Basin) in which individual anhydrite beds extend some $26,000 \mathrm{~km}^{2}$ with only minor changes in thickness and facies (Fracasso and Hovorka, 1986).

The low preservation potential of Precambrian solid sulphate can be related in part to bacterial sulphate reduction within the microbially-dominated ecosystems. Evidence for the former presence of solid sulphate in shallow Neoarchaean seas includes pseudomorphs after selenite, also recorded from the contemporaneous Carawine Dolomite of Australia (Winhusen, 2001), together with rock fabrics and textures typical of evaporite dissolution. Importantly, sulphur isotopes of pyrite samples from the Cambellrand carbonates show a wide range of values indicating biogenic fractionation of sulphate, a signature also seen in the Neoarchaean Belingwe Greenstone Belt of Zimbabwe (Grassineau et al., 2001), and the Mount McRae and Jeerinah shales of Western Australia (e.g., Kakegawa et al., 1998).

\subsection{Chemical versus microbial genesis}

The evidence leads us inevitably to a discussion of the role and scale of microbial processes in taphonomic evolution and carbonate production through time, and of carbonate precipitation itself: there is a clear distinction between overwhelmingly biogenic carbonate precipitation throughout the Phanerozoic, and unresolved processes of carbonate precipitation in the Precambrian. In other words, despite supersaturation of surface sea water with calcite, aragonite 
and dolomite, inorganic precipitation of these phases from the water column does not normally follow (e.g., Leeder, 1982).

Although studies of the early evolution of life and its contribution to the Archaean sedimentary record suffer from a scarcity of preserved microbial remains (Altermann, 2004), there is abundant evidence that the first several billion years of life on Earth was microbial, and Precambrian carbonates are well-known for organo-sedimentary structures such as stromatolites. Proterozoic stromatolites have yielded well-preserved, mostly silicified microfossils that strongly resemble present-day cyanobacteria (e.g., Bitter Springs [Australia], Chickan, Draken, Gunflint and Sukhaya Tunguska formations). The range and combinations of features of fossil stromatolites are often found in living stromatolites, and are difficult, if not impossible, to explain by inorganic processes. Morphology also remains a valid criterion to indicate biogenicity (e.g., Allwood et al. 2006).

In the Precambrian and for much of the Phanerozoic, dolomite $\left[\mathrm{CaMg}\left(\mathrm{CO}_{3}\right)_{2}\right]$ was typically more abundant than limestone - an observation generally known as "the dolomite problem." It remains a source of controversy in sedimentary geology (McKenzie, 1991; Vasconcelos and McKenzie, 1997, 2000; Wright, 1997, 2000; Burns et al., 2000; Wright and Altermann, 2000). A number of kinetic barriers to dolomite precipitation have been shown to operate in the marine environment: (1) the disproportionate distribution of the component ions of dolomite; (2) the low concentration and even lower activity of the $\mathrm{CO}_{3}{ }^{2-}$ ion; (3) the high enthalpy of hydration of the $\mathrm{Mg}^{2+}$ and $\mathrm{Ca}^{2+}$ ions; (4) the presence of $\mathrm{SO}_{4}{ }^{2-}$ ions and the formation of ion pairs. Evidence has been accumulating that SRB are directly involved both in the initial formation and in the diagenetic development of dolomite. SRB were found associated with dolomite concretions, while other types of bacteria as well as archaea dominated in the surrounding sediment. Lipid 
biomarkers and 16S rRNA sequences characteristic of SRB were found in samples from 15 and $40 \mathrm{~cm}$ below the sediment/water interface, depths corresponding with ages of about 500 and 2,000 years (Mauclaire et al., 2002). Dolomite has been produced in low temperature laboratory experiments using SRB from modern dolomitic sediments (e.g., Vasconcelos et al., 1995; Warthmann et al., 2000; Wright and Wacey, 2004, 2005). The key to precipitation of sedimentary, low-temperature dolomite is the removal of the kinetic barriers by microbial mediation. Bacterial sulphate reduction (BSR) can thus provide a "process analogue" for the formation of dolomite through biosphere-hydrosphere-lithosphere interactions, wherever such conditions prevailed in the past. However, it is not always possible to demonstrate a direct link between BSR and calcite precipitation: in laboratory modelling experiments, using a medium mimicking presumed Precambrian seawater chemistry in the presence of the Desulfovibrio desulfuricans, dead or metabolically inactive Desulfovibrio cultures apparently stimulated calcite formation more than active cultures (Bosnak and Newman, 2003).

BSR was much more prevalent in the Precambrian, when microbial communities dominated the environment, generating the potential for major changes in ambient water chemistry in ecosystems across extensive epeiric seas and marine shelves (Wright, 2000; Wright and Altermann, 2000; Altermann et al., 2006; Eriksson et al., 2009a). Shen and Buick (2004) provide evidence from $\delta^{34} \mathrm{~S}$ values of microscopic pyrites in former gypsum crystals in the $\sim 3.47 \mathrm{Ga}$ North Pole barite deposit of northwestern Australia for the oldest example of microbial sulphate reduction and the earliest indication of a specific microbial metabolism.

Thin section studies show that sedimentary carbonate was the earliest mineral precipitate at several different levels in the Dresser Formation, while trace element analysis of carbonate from the lower part of the Dresser Formation indicates ankerite precipitation from seawater under 
anoxic conditions (Garcia-Ruiz et al., 2003; Van Kranendonk et al., 2003). Foriel et al. (2004) used fluid inclusions from quartz in lava escape tubes of overlying pillow basalts to show a strong similarity to modern seawater, apart from a higher concentration of dissolved salts. Does this mean that the carbonate was a direct seawater precipitate? This is a debatable subject. Large volumes of sulphate were present in the Dresser Formation, as evidenced by the presence of primary barite, with SRB present (Shen and Buick, 2004), indicating strongly that carbonate precipitation occurred alongside microbial mediation of ambient waters.

Mass microbial colonisation across extensive Neoarchaean epeiric seas witnessed the microbiogeochemical transformation of the Earth's hydrosphere, atmosphere and biosphere. The consequences for a reducing ocean would have been the progressive oxidation of the major dissolved species in surface seawater, most notably of reduced sulphur and iron. Cyanobacterial photosynthetic oxidation of surface seawater drove formation of aqueous sulphate and permitted the precipitation of extensive evaporites in restricted basins. The first dramatic explosion of carbonate precipitation can be related to intense bacterial sulphate reduction in association with anoxic organic diagenesis and pyrite formation within the decaying interiors of microbialites and in sapropels.

It has been argued that stromatolites were originally formed largely through in situ precipitation of laminae during Archaean and older Proterozoic times, but that younger Proterozoic stromatolites grew largely through the accretion of carbonate sediments, most likely through the physical process of microbial trapping and binding (Grotzinger and Knoll, 1999). Historically, early mineralisation of microbialites has been attributed to abiotic submarine cementation, or to calcification of cyanobacterial sheaths induced by photosynthesis (e.g., Logan, 1961; Monty, 1976; Dill et al., 1986). However, the kinetic barriers to dolomite formation also 
apply to a lesser extent to abiotic calcium carbonate precipitation, and these can similarly be overcome by microbial mediation (e.g., Wright and Oren, 2005 and references therein). Recent work has shown that bacterial sulphate reduction is associated with in situ carbonate precipitation in many modern settings (e.g., Canfield and Raiswell, 1991; Hendry, 1993; Reid et al., 2000; Walter et al., 1993; Visscher et al., 1998, 2000; Wright, 1999, 2000; van Lith et al., 2003; Wright and Wacey, 2004, 2005).

The link between bacterial sulphate reduction and calcification has been investigated in modern marine stromatolites of Exuma Sound, Bahamas. Visscher and co-workers showed a direct link between sulphate reduction and aragonite precipitation, with cumulative lithified laminae formed by microbial activity near the sediment surface (Reid et al., 1995, 2000; Golubic and Browne, 1996; Macintyre et al., 1996; Feldman and Mackenzie, 1998). Field and experimental work by Reid et al. (2000) has also shown that the growth of modern stromatolites in the Bahamas is achieved through a dynamic balance between in situ carbonate precipitation associated with SRB, and sedimentation by trapping and binding of grains, each process being closely related to a different microbial community depending on environmental dynamics.

In situ precipitation was shown to occur in continuous surface layers of exopolymer secreted by cyanobacteria, associated with both aerobic and anaerobic microbial consortia. SRB are an important component of the surface layer, accounting for up to $40 \%$ of carbon consumption by the community, despite the presence of oxygen at the surface. Distinct bands of SRB activity were found, located exactly at the lithified micritic horizons. High rates of sulphate reduction associated with degradation of exopolymers coincided with aragonite precipitation in the stromatolitic surface crusts, while radiolabelled organic matter revealed elemental exchange 
between bacteria and aragonite needles. Carbonate precipitation associated with exopolymers may also explain the rarity of microbial fossils in ancient microbialites.

The association between cyanobacteria and SRB as key components within the microbial communities responsible for the construction of the Bahamian stromatolites has huge implications for the understanding of carbonate precipitation not only in ancient microbialites, but also for the accumulation of thick platformal carbonates and for non-skeletal sedimentary carbonate precipitation throughout the geologic record.

\subsection{Molar tooth structure}

One feature distinctive of Precambrian carbonates, particularly those of shelf origin, is molar tooth structure (MTS), a crack-fill cement of unique character. It is almost exclusive to Mesoproterozoic and early Neoproterozoic times (900-600Ma), preferably the latter (Meng and $\mathrm{Ge}, 2002)$. The cement mass is unzoned, being constituted by uniform-sized sucrosic carbonate crystals, calcite or dolomite, generally sheet-like in three-dimensional geometry, conspicuous when subvertical in attitude, wispy in cross-section, often ptygmatically folded, and laminae in host sediment are differentially compacted around them (Fig. 20). The last two features as well as evidence for transport of fragments clearly indicate early generation of the cement. MTS can, however, be horizontal, spindle-shaped and ribbon- or blob-shaped also.

Widely different views have been proposed for the origin of MTS over the last half century, but the structure still remains enigmatic. It has been thought by some to be derived from noncarbonate precursors, such as algal structures (Smith, 1968; O'Connor, 1972; MoussinePouchkine and Bertrand-Sarfati, 1997) or evaporite minerals (Eby, 1977). The majority opinion, 
however, does not question its primary carbonate composition, considers it not as a replacement product but as crack-filling cement; these researchers, nevertheless differ widely with regard to the mechanism for crack generation. Tectonic fracturing (Daly, 1912; Cowan and James, 1992; Smith and Winston, 1997; Bishop and Sumner, 2006), earthquake induced dewatering (Fairchild et al., 1997; Pratt, 1998b), desiccation or synaeresis (Bell, 1966; Horodyski, 1976, 1983; Young and Long, 1977; Hofmann, 1985; Beukes, 1987; Knoll and Swett, 1990; Calver and Baillie, 1990; Demicco and Hardie, 1994; Liu et al., 2005) and fluid pressure (Dix and Mullins, 1987; Desrochers and Al-Aasm, 1993; Mozley and Burns, 1993; Furniss et al., 1994, 1997; James et al., 1998; Kuznetsov, 2003; Pope et al., 2003; Marshall and Anglin, 2004; Pollock et al., 2006) have all been suggested in this respect.

None of the processes mentioned above, however is exclusive to the Meso-Neoproterozoic period and the age preference of the structure remains unexplained. Shields (2002) held maximum accentuation in ionic concentration of $\mathrm{Ca}^{+2}$ and $\mathrm{CO}_{3}^{-2}$ in Neoproterozoic seawater to be responsible for this preference. Frank and Lyons (1998) supported a unique genetic combination of $\mathrm{CaCO}_{3}$ saturation and redox conditions, in shallow marine waters in the absence of biotic agronomy. Marshall and Anglin (2004) postulated that destabilization of $\mathrm{CO}_{2}$-clathrate by some mechanism, such as seismic shocks, could have created the MTS, and explained the preferential Proterozoic chronology by stabilization of the clathrate in the sediment column because of higher partial pressure of $\mathrm{CO}_{2}$ in the extant atmosphere. Meng and $\mathrm{Ge}$ (2002) contemplated a relation between MTS and prevalent bioforms transitional to Phanerozoic multicellular forms, and suggested that related micro-bioelectromagnetic waves encouraged $\mathrm{CaCO}_{3}$ precipitation within cracks induced by $\mathrm{CO}_{2}$ overpressuring. Pollock et al. (2006) proposed intimate links between crack formation and concomitant microspar precipitation and 
the decomposition of sedimentary organic matter in the presence of supersaturated seawater; they produced a variety of crack morphologies within unconsolidated mud under gas pressure in the laboratory. Proliferation of sulphate reducing bacteria and methanogens in the Proterozoic time period could have promoted carbonate precipitation within cracks (e.g., Vasconcelas and McKenzie, 1997; Wright, 1999; van Lith et al., 2003; Roberts et al., 2004; Wright and Oren, 2005; Wright and Wacey, 2004, 2005).

Two generations of MTS coexisting within the Neoproterozoic Bhander Limestone of the Vindhyan Supergroup in the area around Maihar, central India and within the Mangurda Limestone of the Pranhita-Godavari Valley Basin, in the area north of Adilabad, South India (Fig. 1) provide a rare insight into MTS formation. In these limestone formations, vertical MTS cut across the horizontal MTS indicating their later generation. Differential compaction of host sediment around the vertical group, nevertheless indicates only a short time gap between the two generations, with both belonging to early diagenesis. In both limestones the preferred lithology for MTS occurrence is ribbon limestone facies characterized by frequent alternations between light coloured carbonate lutite and darker coloured very fine-grained marl laminae. Cracks are abundant at certain stratigraphic levels; with the majority of them being parallel to bedding the limestone appears almost shredded, an appearance that has been attributed to synsedimentary earthquakes (Fig. 21; Coniglio, 1986; Chakraborty, 1995). Primary laminae of the host sediment as well as the bed-parallel crack-fill MTS are differentially compacted against the vertical, relatively less common, second generation MTS.

It is apparent that these Indian examples of MTS, even those of the second generation, formed before consolidation of the host sediment. Cementation, which is generally rapid in carbonates, was relatively delayed in this case, for the host sediment. Although this fact argues against the 
common belief that concentration of $\mathrm{Ca}^{+2}$ and $\mathrm{CO}_{3}^{-2}$ ions had been high in Neoproterozoic sea water (Grotzinger and Kasting, 1993; Kaufman and Knoll, 1995; Frank and Lyons, 1998; Shields, 2002), the delayed cementation can alternatively be attributed to preponderance (possibly localised) of inhibitors to $\mathrm{CaCO}_{3}$ precipitation, like $\mathrm{Mg}^{2+}, \mathrm{Fe}^{2+}, \mathrm{PO}_{4}{ }^{3-}$ or $\mathrm{SO}_{4}{ }^{2-}$ ions. Both the Bhander Limestone and the Mangurda Limestone contain pseudomorphs after gypsum (Fig. 22). The former also contains barite within second generation MTS, and is furthermore encased by red beds themselves containing pseudomorphs after gypsum and halite (Bose et al., 2001). High concentration of inhibitors like $\mathrm{SO}_{4}{ }^{-2}$ in the concerned seawater is thus a logical conclusion. Sediment pore fluid could have become progressively enriched in salts which were more difficult to precipitate as it was squeezed out from the host sediment and entered the first generation MTS cracks, and then moved from there into the MTS cracks of the second generation. Evaporite mineral alteration from gypsum in the host sediment to barite in the second generation MTS amply supports such a postulated course of pore fluid evolution.

Similarity between the MTS of the two different generations (attitudes) is overwhelming, both being constituted by clear microspar crystals, with crystal size being comparatively more uniform in the case of the second generation MTS; boundary-parallel crystal-size zonation, i.e. drusy growth, a common characteristic of void-fill cement, is absent in both the cases. Crystals constituting the MTS are largely bright, while those in the host sediment appear to be predominantly dull under cathode luminescence. Bright crystals, nonetheless, are also found scattered within the host sediment in the immediate vicinity of the MTS, decreasing in frequency of occurrence away from them (Fig. 23) (Amieux, 1982). This outwardly diminishing halo of bright crystals around the MTS suggests that the pore fluid that traveled mostly along the cracks also permeated the sediment beyond the crack walls. Crack formation might have preceded the 
fluid flow or could be tied up with it, being triggered by a common mechanism, such as earthquake seiches. Preferred occurrence of MTS within the shredded part of the same ribbon limestone strongly corroborates the possibility of earthquake seiches.

The $\delta^{18} \mathrm{O}$ values in (apparently least altered) micro-drilled samples from both first and second generation MTS as well as from the sediment hosting them within the Bhander Limestone and the Mangurda Limestone, are all moderately negative, while the corresponding $\delta^{13} \mathrm{C}$ values are all positive. The latter tend to be comparatively lower in the host sediment than in the MTS, this contrast being relatively more profoundly expressed in the Mangurda Limestone samples (Fig. 24). ${ }^{87} \mathrm{Sr} /{ }^{86} \mathrm{Sr}$ values, on the other hand, have very limited ranges in the MTS samples, although they are comparatively lower in the Mangurda Limestone than in the Bhander Limestone. The ${ }^{87} \mathrm{Sr} /{ }^{86} \mathrm{Sr}$ ratios in the sediments that host the MTS are, however highly variable, greater variation and significantly higher values being found in the Mangurda Limestone; a variable fluid-rock ratio is inferred. Plotting of ${ }^{87} \mathrm{Sr} /{ }^{86} \mathrm{Sr}$ values of the samples against their $\delta^{13} \mathrm{C}$ values clearly separates the MTS and the sediment that hosts them (Fig. 24). The $\delta^{18} \mathrm{O}$ and $\delta^{13} \mathrm{C}$ values decrease with diagenetic alteration (Choquette, 1968; Veizer et al., 1992; Kaufman and Knoll, 1995; Kah, 2000; Pope et al., 2003) and the positive values of the latter isotope, in contrast to the negative values of the former, as noted in the two studied limestones, are consistent with greater stability of $\delta^{13} \mathrm{C}$ during diagenesis (Hudson, 1977). Comparatively higher and widely variable ${ }^{87} \mathrm{Sr} /{ }^{86} \mathrm{Sr}$ values in the host sediment further corroborate a distinctly higher degree of diagenetic alteration, because diagenetic fluid is dominantly influenced by ${ }^{87} \mathrm{Rb}$ that is derived from silicate minerals and changes into ${ }^{87} \mathrm{Sr}$. The MTS evidently largely escaped this alteration (Fairchild et al., 2000; Shields, 2002) and their ${ }^{87} \mathrm{Sr} /{ }^{86} \mathrm{Sr}$ ratios (which are as low as c. 0.706 ) may reasonably be the result of accentuated hydrothermal activity (Veizer and Compston, 1976; Veizer et al., 1983; 
Jacobsen and Kaufman, 1999). This differential response to diagenesis between the host sediment and the MTS could possibly be due to variation in primary mineralogy, i.e. more stable carbonate in the MTS, such as low Mg-calcite or dolomite.

A progressive increase of salinity in residual pore fluid as it passed from the host sediment to the first and then to the second generation of MTS cracks could have increasingly facilitated precipitation of carbonate and also favoured the mineral phase of lower diagenetic potential, viz. dolomite or low-Mg calcite, in lieu of aragonite and high $\mathrm{Mg}$ calcite. This would explain why the host sediment remained uncemented while precipitation took place within the cracks. With progressive increase in soluble salt concentration, the pore fluid could have become gel-like, with resultant precipitation therefrom becoming unzoned, and without much variation in crystal size.

Extensive development of shallow hypersaline water bodies is inferred for the epeiric seas that developed widely during the Proterozoic, especially in its later stages. It is likely that pore-fluid pressure itself created the cracks and that depressurisation in consequence of crack-opening could have facilitated carbonate precipitation as well; crack-generation and -filling thus resulted from a single mechanism, pore fluid overpressuring. Earthquake seiches, in turn, could have been responsible for inducing the pore fluid overpressuring. The combination of earthquakes and extensive development of quiet stratified epeiric sea bodies apparently encouraged MTS formation selectively in Meso- and Neoproterozoic times, but more preferably in the Neoproterozoic.

\subsection{Carbonate rocks, global palaeoclimate change, and glaciation}


Although glacigenic deposits are essentially clastic rather than chemical in their nature, they appear to be genetically closely linked to isotopic values determined from directly associated carbonate deposits reflecting significant changes in global climates and possibly also palaeoatmospheric conditions; hence they are discussed here rather than in the earlier, clastic part of the paper. The placing of this section also serves to emphasize that the clastic and chemical sedimentary record of the Precambrian needs to be studied holistically. Additionally, of all the clastic deposits, those ascribed to glacigenic depositional systems show the smallest divergence from Phanerozoic equivalents (both the deposits and the inferred palaeoenvironmental processes), while maintaining the most complex array of possible geneses, all seemingly related to major global changes which occurred more than once and at specific times in Earth history rather than either changing gradually, or having been subject to major change at a single, specific time (e.g., Eriksson et al., 1998; their Table 1; references therein).

Widespread negative $\delta^{13} \mathrm{C}$ excursions in carbonate rocks appear to have been related to major glaciations (e.g., Kaufman et al., 1991, 1997; Frimmel et al., 2002), while in contrast, an enrichment of ${ }^{13} \mathrm{C}$ may be linked to preferential fixation of ${ }^{12} \mathrm{C}$ during photosynthesis in stagnant environments (e.g., Schidlowski et al., 1976; Hayes et al., 1999; Rothman et al., 2003). At the beginning and end of the Proterozoic Eon (2500-543 Ma), Earth experienced a period of glacial conditions, with evidence for large continental ice sheets that may have extended to sea level at low latitudes (e.g., Evans et al., 1997; Williams and Schmidt, 1997; Schmidt and Williams, 1999; Sohl et al., 1999; Kempf et al., 2000). These two major glaciogenic intervals show some striking similarities: both coincide with supercontinent rifting; both feature "cap carbonates" regionally persistent, continuous, thin intervals of limestone and/or dolostone that sharply overlie 
glacial or related deposits, on almost every continent, even in regions otherwise lacking carbonate strata, and these cap carbonates are characteristically depleted in ${ }^{13} \mathrm{C}$.

The oldest known mid-latitude glaciation, recorded in the Pongola Supergroup (Kaapvaal craton) diamictite, occurred at $2.9 \mathrm{Ga}$ (Nhleko, 2003). At least three discrete intervals of glacial activity punctuate the Early Palaeoproterozoic geological record between about 2.45 and $2.22 \mathrm{Ga}$ (e.g., Hambrey and Harland, 1981) and are believed to be associated with assembly and rifting of a Late Archaean supercontinent ("Kenorland"; Williams et al., 1991). Of these, the best-known and best-preserved belong to the Huronian Supergroup of Canada and the Transvaal Supergroup of southern Africa. Although three discrete episodes of glaciation have been recorded in several widely spaced sedimentary successions in North America, there are very few carbonates in this interval (Young et al., 1998; Bekker et al., 2005).

Glaciogenic units in the Transvaal Supergroup are found within two of the three separate preservational basins (Fig. 9), with a prominent diamictite (Makganyene Formation; Griqualand West basin; age poorly constrained at $<2.43 \mathrm{Ga}$ and $>\sim 2.22 \mathrm{Ga}$; Cornell et al., 1996) in the one, and three discrete, but thin and laterally restricted diamictites within the second (the two lower units occur in the Duitschland Formation and both have associated carbonates; age of formation $<2.43 \mathrm{Ga}$ and $>2.23 \mathrm{Ga}$, Hannah et al., 2004; the upper unit is in the Upper Timeball Hill Formation, $<2.23 \mathrm{Ga}$ and $>2.22 \mathrm{Ga}$; all in the Transvaal basin). The lower Duitschland cap carbonate was deposited above glacial diamictite on an open-marine margin during oceanic transgression and records $\delta^{13} \mathrm{C}$ depletion in carbonates with values ranging from $-3.7 \%$ to $0.1 \%$, as well as ${ }^{13} \mathrm{C}$-enrichment in organic matter (Bekker et al., 2001). The consistently negative $\delta^{13} \mathrm{C}$ values of these cap carbonates contrast with the younger Duitschland carbonates (above the second diamictite, which is apparently non-glacial) above a notable sequence boundary, which 
are significantly enriched in ${ }^{13} \mathrm{C}$ up to $+10.1 \%$. Palaeomagnetic data from the Transvaal Supergroup shows that the glacial diamictites were deposited within about $11^{\circ}$ of the equator at 2.22 Ga (Evans et al., 1997), indicating a near-global glaciation. In North America, the three Huronian diamictites have no reliable palaeolatitudinal constraints, and only one is overlain by a cap carbonate, which recorded negative $\delta^{13}$ Ccarb, and enriched $\delta^{13}$ Corg (Kopp et al., 2005).

The Palaeoproterozoic glaciations were followed by a sharp reversal in the C-isotope signatures of carbonates globally, marked by a positive $\delta^{13} \mathrm{C}$ carbon isotope excursion, with $\delta^{13} \mathrm{C}$ values typically ranging from +7 to $+12 \%$, known as the $2.2-2.1$ Ga Lomagundi-Jatuli event (e.g., Schidlowski et al., 1975; Galimov et al., 1975; Schidlowski and Todt, 1998). This Palaeoproterozoic $\delta^{13} \mathrm{C}$ positive anomaly has a global character, with fractionation between inorganic and organic carbon in ${ }^{13} \mathrm{C}$-enriched carbonates close to $30 \%$, and represents a major perturbation of the global carbon cycle in geological history. The carbon isotope excursion began earlier than $2.22 \mathrm{Ga}$ in the Fennoscandian and Canadian shields. Sedimentary successions with an age between 2.2 and 2.1 Ga contain evidence for warm arid climate including pseudomorphs after sulphate and halite, magnesite and red beds. They are devoid of BIFs. The magnitude and duration of the unique Lomagundi-Jatuli Event is documented in back-arc basins formed during ocean closure and subduction. The data imply that isotopically light carbon from organic-rich, passive margin sediments accumulated during subduction into the lower crust and mantle (Melezhik et al., 2007). Carbon isotope values are strongly correlated with environmental setting: playa and sabkha stromatolitic dolostones are most enriched, whereas those from intertidal settings exhibit lower $\delta^{13} \mathrm{C}$ values (Melezhik et al., 2005). These facies-dependent trends suggest that the global $\delta^{13}$ Ccarb excursion was amplified by up to $8 \%$ by local bioenvironmental factors. The Lomagundi-Jatuli carbon isotope excursion ended between 2.11 and 
2.06 Ga. Carbon isotope values of carbonates deposited shortly afterwards range between 0 and $+3 \%$. The end of the excursion coincided with deposition of Mn-carbonates, phosphorites, BIFs, organic-rich shales, the oldest fossils of possible eukaryotic origin, and a decrease in stromatolite abundance.

The Mesoproterozoic appears to have been a time of relative environmental stability, and carbonate successions usually have $\delta^{13} \mathrm{C}_{\mathrm{PDB}}$ values close to $0 \%$, similar to Phanerozoic successions (Veizer et al., 1980; Buick et al., 1995; Kah et al., 1999). The Mesoproterozoic was also a time of great stromatolite abundance and diversity. While Mesoproterozoic carbonates are known to have carbon isotope values close to $0 \% \delta^{13} \mathrm{C}$, Neoproterozoic rocks may have values ranging from -12 to $+13 \%$, or greater (e.g., Knoll et al., 1986; Magaritz et al., 1986; Kaufman and Knoll, 1995; Iyer et al., 1995; Buick et al., 1998; Santos et al., 2000). Large negative excursions are associated with transgressive "cap carbonates", typically of dolostone and found above diamictites, reflecting deglaciation and a supposed paradox where glacial deposits, and carbonates assumed to require a warm climate, are in close contact. Higher $\delta^{13} \mathrm{C}$ values are usually associated with burial of ${ }^{12} \mathrm{C}$-rich organic matter.

The widespread glaciations of the Cryogenian $(850-630 \mathrm{Ma})$ have been associated with large-scale carbon isotope perturbations, the "Snowball Earth" hypothesis, and the rise of metazoan life in the Ediacaran period (Hoffman et al., 1998; Knoll and Caroll, 1999; Hoffman and Schrag, 2002; Knoll, 2003; Chen et al., 2004; Condon et al., 2005; Halverson et al., 2005). The "Snowball Earth" glaciation may have extended to very low latitudes, possibly right to the equator (Kirschvink, 1992; Hoffman and Schrag, 2002). The Cryogenian Period (850-630 Ma) includes the Sturtian Glaciation ( $\sim 720-700 \mathrm{Ma})$ and the Marinoan ice ages, $\sim 650$ to $\sim 630 \mathrm{Ma}$ (Martin et al., 2000; Smith, 2009). Kilner et al. (2005) report palaeomagnetic data from the 
Neoproterozoic Huqf Supergroup of Oman that yield a palaeopole that places the Muscat region of Oman at a latitude of $13^{\circ}$ in the late Neoproterozoic, providing direct evidence that both glacial and overlying cap carbonate units were deposited in the tropics.

The Precambrian-Cambrian boundary marks a significant change in the nature and mineralogy of carbonate sediments, intimately associated with the emergence and diversification of metazoans. The preservation potential of the earliest shells was poor, since they were thin walled and often of aragonite, and therefore highly susceptible to destructive neomorphosis, dolomitisation or phosphatisation. Nevertheless, these changes brought an end to the deposition of large-scale Precambrian-style carbonates associated with microbial processes, and heralded the beginning of a new and very different era of carbonate sedimentation patterns. There is a clear dichotomy between skeletal carbonate precipitation associated primarily with Metazoa, algae and Protozoa throughout the Phanerozoic, and largely unresolved processes of carbonate precipitation in the Precambrian.

\section{Discussion}

This paper provides an overview of Precambrian sedimentation systems through examination of the siliciclastic and carbonate rock records, and highlights differences compared to their Phanerozoic counterparts. Critical appreciation of some features of proven Precambrian bias serves to highlight what are in essence relatively small differences.

Precambrian rivers tended to be braided in the absence of any vegetation and with poorly developed soils (e.g., Schumm, 1968; Cotter, 1978; Long, 1978, 2004; Fuller, 1985; Els, 1990; Rainbird, 1992); however, channel incision into the bedrock during fall and overbank mud 
deposition during rise of the base profile favoured fixed channels, as shown by the fluvial interval at the base of the Neoproterozoic Sonia Formation in India (e.g., Samanta et al., 2007, 2008; Samanta, 2008). Although it can logically be assumed that climate was more effectual in controlling erosion and deposition in the absence of vegetation, the two unconformities that intercept the Sonia fluvial interval apparently owed their genesis largely to tectonism. Significant deviation in palaeocurrent direction across them and also selective occurrence of water escape structures under the relatively younger unconformity all over the study area support this suggestion (Samanta, 2008; Sarkar et al., 2005, 2008). The accentuated impact of climate change could also have made Precambrian rivers flashier, more often ephemeral (e.g., Tirsgaard and Øxnevad, 1998; Mueller and Corcoran, 2001; Eriksson et al., 2009a). Steeper gradients than usually found in rivers, estimated from three Palaeoproterozoic river deposits in the Waterberg Group, South Africa (Fig. 5) suggest occasional and localised steepening of depositional slope because of enhanced production (under high atmospheric $\mathrm{CO}_{2}$ ) and localized deposition of clay during flash floods (Eriksson et al., 2006, 2008a).

In the absence of vegetation the aeolian regime should purportedly have been far more extensive during the Precambrian than in the Phanerozoic. Notwithstanding this, large erg deposits only became commonplace since $\sim 1.8 \mathrm{Ga}$, possibly reflecting small cratons and a strong oceanic (humidity) influence on palaeoclimatic regimes prior to that (Eriksson and Simpson, 1998). Growth of large continental masses could thus have been critical for extensive development of aeolian ergs (Eriksson and Simpson, 1998) and supercontinentality may only have become widespread on Earth by about $2.2-1.8$ Ga (e.g., Eriksson et al., this volume). Widespread rifting after c. $1.8 \mathrm{Ga}$, plausibly related to the assembly of supercontinent Laurentia and concomitant orogenesis (cf., Hoffman, 1988) may have enhanced the rate of creation of the 
all important preservation space for Precambrian aeolianites. Nevertheless, water table fluctuation must have been a prime factor controlling supply of sand and preservation of aeolinites, as it is now also.

The sea water composition seemingly changed from its likely initial acidic to subsequent alkaline state from the Precambrian to the Phanerozoic (section 3). The temporal change in sea water composition is best manifested in the exclusive occurrence of giant botryoids of aragonite (Fig. 19), metres-thick Mg-calcite beds as well as the rare occurrence of evaporitic sulphate in the Archaean (section 3.2 and references therein). Either low sulphate concentration or a high bicarbonate : carbonate ratio in the early sea water is implied. The Precambrian marine record is dominated by deposits of epicontinental seas, deep marine deposits being very scarce and then commonly associated with inferred ophiolitic successions, of sometimes controversial veracity (e.g., Eriksson et al., 2008b). Abundant peritidal deposits manifest sedimentation in epeiric embayments, while some storm successions document development of epeiric seaways. Vertical amalgamation of supralittoral marine storm beds resulted from the low gradient of the epeiric sea coasts (Sarkar et al., 2005). The low shelf gradient and wide proliferation of microbial mat, a typical Precambrian phenomenon, combined to restrict the epeiric sedimentation budget and that, in turn, may have favoured vertical stacking of highstand systems tracts at the expense of transgressive systems tracts (Sarkar et al., 2005; Catuneanu and Eriksson, 2007). Along the coastlines of epeiric seas, large braided fluvial systems debouched, and braid-deltas were likely to have been common (Nemec and Steel, 1988; Els, 1998); a close association of braided river systems and epeiric coastline facies is often observed in Precambrian shallow marine successions and may even have been a diagnostic feature (as postulated by Eriksson et al., 2008b) for an apparently largely exclusively Precambrian environmental setting. The multiple shallow marine 
formations cited here from Africa and India range in age from the Archaean to the Neoproterozoic and depict the entire range of variation from tide domination to wave supremacy.

With regard to deltaic systems little difference in terms of depositional environments and processes is inferred between Precambrian and Phanerozoic examples. The Precambrian delta deposits may, nonetheless, be incomparably thicker ranging up to $3,500 \mathrm{~m}$; high sedimentation rate induced by aggressive weathering (Corcoran et al., 1998; Donaldson and de Kemp, 1998) and lack of vegetation was likely the prime cause for such overthickening (e.g., Eriksson et al., 1998 and references therein). Abundance of soft sediment deformation structures not only in the delta slope deposits, but also in the prodelta deposits, suggests steepness of the depositional surface; rift-related subsidence can account for this relatively steeper palaeoslope as well as the accommodation space needed to explain the unusually large thickness of many Precambrian delta deposits (cf., Eriksson, 1979; Siedlecka et al., 1989). These factors in conjunction with bedload dominance and lack of bank stability in the rivers can also explain the common occurrence of braid-deltas in the Precambrian record. Lack of channel stability also renders distinction between delta plain and delta platform difficult within Precambrian delta deposits, with flows appearing non-channelized in both settings.

An essentially unique feature of the Precambrian period was the widespread growth on most subaqueous clastic sediment surfaces within the photic zone, of prolific microbial mats and their often spectacularly preserved proxy features (Walter and Heys, 1985; Schopf, 1999; Hagadorn and Bottjer, 1999; Schieber et al., 2007). Even within the c. 1.8 Ga Waterberg Group desert in Kaapvaal, microbial mats flourished in playa settings before being destroyed in flash flood reworking of these shallow aqueous settings (e.g., Eriksson et al., 2000). The oldest known clastic mat features go back to 2.9 Ga (Noffke et al., 2006). Although often subtle in their 
preservation, particularly within the mudrocks, mats played an important role in binding sediment, and possibly even in altering sediment dynamics and stacking patterns at the local scale (e.g., Sarkar et al., 2005); in the Phanerozoic, they were still present (and are still so today) but suffer from commonly excessive destruction and poor preservation potential through the action of metazoan grazers (e.g., Schieber, 1998). The growth of microbial mats along coastlines required several weeks of non-burial, as shown by laboratory experiments (e.g., Gerdes and Klenke, 2003, 2007), and this implies an episodic sedimentation regime along both coasts and also possibly in braided river systems debouching into epeiric seas (e.g., Eriksson et al., 2009a). The latter postulate supports the indication of episodic fluvial systems in the Palaeoproterozoic derived from palaeohydrological calculations, and related to a long-lived greenhouse palaeoatmosphere by Eriksson et al. (2009a).

While modern uniformitarianism ("the present is the key to the past"; e.g., Hallam, 1990) may reasonably be applied to the clastic sedimentation systems discussed in this paper, bearing in mind the important caveat that it is the variation in rates and intensities rather than in the processes and products that distinguishes the Precambrian (e.g., Donaldson et al., 2002), the carbonate sedimentary record is less amenable to this panacean principle. The latter observation can be ascribed largely to the limitations in our understanding of abiotic carbonate precipitation processes, and to the ongoing debate on the chemical composition and attributes of ancient seawater.

There is no unequivocal empirical evidence that calcium carbonate or dolomite precipitates directly from modern seawater (e.g., Leeder, 1982; Wright, 2000; Morse et al., 2003; Wright and Oren, 2005), and it has been suggested that kinetic inhibitors to carbonate precipitation are especially effective in saline waters. However, there is abundant evidence that these inhibitors 
can be overcome through microbial mediation (e.g., Slaughter and Hill, 1991; Robbins and Blackwelder, 1992; Robbins et al., 1996; Warthmann et al., 2000; Wright, 2000; Wright and Altermann, 2000; Wright and Wacey, 2004, 2005; Wright and Oren, 2005). Modern marine carbonate production is almost exclusively biologically mediated, but in the Precambrian, skeletal biotas were unknown and prokaryotes (and from c. $2.1 \mathrm{Ga}$ possibly, eukaryotes also) dominated every ecosystem. The question that arises therefore is: to what extent was carbonate precipitation microbially-mediated in the Precambrian? The answer has been sought through theoretical models and assumptions about physico-chemical processes, but real progress has only been achieved through detailed observation of modern processes and ecosystems, and experiments that realistically simulate past microbiogeochemical environments (sections 3.3 and 3.4). While microbially induced carbonate precipitation has been demonstrated in many, welldocumented experiments, the scale at which it operates in the natural environment has yet to be quantified, but is likely to have been very significant.

Microbial consortia often exhibit an ability to change the chemistry of a solution and to control $\mathrm{pH}$ at the microscale, passively or actively. This leads to oversaturationof $\mathrm{Ca}^{2+}$ and $\mathrm{CO}_{3}{ }^{-2}$ ions and to the removal of kinetic inhibitors to carbonate precipitation, like sulphate or phosphate. The kinetic barriers of low carbonate ion activity, ion hydration and ion complexing, especially in saline waters, inhibit spontaneous carbonate mineral precipitation from saturated solutions but oxygenic photosynthesis and sulphate reduction by sulphate-reducing bacteria can overcome these natural barriers. Sulphate in seawater tends to form pairs with $\mathrm{Ca}^{2+}$ and $\mathrm{Mg}^{2+}$ ions, particularly the latter (Garrels and Christ, 1965; Wright, 2000; Wright and Oren, 2005). The removal of sulphate reduces complexing, raises carbonate alkalinity, and along with pyrite formation, enhances carbonate precipitation. Cyanobacteria can store $\mathrm{Ca}^{2+}$ and $\mathrm{Mg}^{2+}$ ions in 
organic envelopes and precipitate carbonates within their sheaths and extracellular polymeric substances, thus triggering sedimentary carbonate production. In the Precambrian, organic influence was restricted to microbes.

The morphology, facies associations and arrangement of architectural elements in Archaean stromatolites have been used to argue for a biological origin of stromatolitic lamination preserved in Archaean cherts and carbonates (e.g., Allwood et al., 2006). The observed behaviour of in situ laminae accretion and sediment trapping and binding cannot be explained by abiogenic carbonate precipitation from saturated seawater. The increasing complexity of Precambrian stromatolitic structures over time provides additional evidence for biologic control on stromatolite formation, and supports a strong argument that biogenic stromatolites and microbial mats were present at $\sim 3.47 \mathrm{Ga}$, before becoming increasingly widespread, abundant and diverse through the Proterozoic (sections 3.1 and 3.2). Current evidence thus suggests that Archaean carbonate sedimentation resulted from a combination of hydrothermal and biochemical processes. The latter processes probably led to the first formation of low-temperature carbonates on the limited areas of continental shelf-type environments. Although atmospheric $\mathrm{CO}_{2}$ was much higher than today, giving rise to acidic oceans, biochemical processes in shallow water microbiota mediated ambient water composition to produce alkaline, reducing conditions in which the kinetic barriers to carbonate precipitation were removed, forming the first carbonate deposits. Thus low-temperature carbonate precipitation was closely linked to earliest life, and as benthic microbiota spread across developing continental shelves and epeiric seas in the form of stromatolites and other microbialites, acted as major repositories for carbonates. Interactions between micro-organisms and their environments have generated a variety of facies and microfacies in platformal carbonates, both by in situ precipitation and by sediment trapping and 
binding. The interplay of cyanobacteria and heterotrophic bacteria has thus been the major contributor to carbonate precipitation for at least the last 2 billion years of Precambrian history.

Creation of vast shallow epeiric seas during the Proterozoic, especially during its later part, made the shallow marine basinal environment more conducive to development of the factors stated above and thereby accentuated the possibility of direct precipitation of carbonates from sea water. In consequence, molar-tooth cracks that probably owed their origin to overpressuring of pore fluids were filled immediately by carbonate cement crystals that acquired a comparatively more uniform size and a stable mineralogy, and an unzoned nature within cracks of a comparatively later generation.

\section{Conclusions}

The range of variation that the Earth-system has undergone through time is prodigious, and this must have impacted on the physical-chemical-biological milieu of sedimentation. This has imposed certain temporal controls on the development of specific settings and sedimentation systems; as an example, prior to c. $1.8 \mathrm{Ga}$ wind deposits of limited scale did develop, but large scale ergs only formed once large land masses resulted following the formation of supercontinents such as Laurentia or Kalahari after c. 2.2 - 1.8 Ga. Glaciation of apparently limited scale is known from the Archaean, and two global glaciation events in the Palaeoproterozoic and Neoproterozoic also underline the importance of chronological control on global-scale events, yet this should be seen against the backdrop of time-independent action of apparently uniformitarian processes and facies-scale sedimentary products. Precambrian deltas closely resemble their Phanerozoic counterparts, except for a strong influence of tectonism on 
apparently enhanced subsidence and sedimentation rates in early Precambrian examples prior to formation of large continental land masses; the braided nature of distributary channels reflects the influence of an absence of vegetation on all channel systems, deltaic, alluvial, fluvial and even tidal drainage networks (e.g., Eriksson et al., 1998). Precambrian lake deposits are not widely reported, and then with some bias towards identification of arid or semi-arid examples (related by some schools of thought to ancient greenhouse palaeo-atmospheric regimes); however, distinction of freshwater lake deposits from low energy epeiric shoreline settings remains difficult.

While the sedimentation processes and products within glacial, desert, delta, possibly also lake settings strongly resemble their Phanerozoic counterparts, and whereas inferred controls on basin evolution and -filling appear equally comparable in a majority of cases (e.g., Eriksson et al., 2005, 2007 and references therein), preservation of shallow marine environments and the characteristics of Precambrian fluvial sediments are less straightforward. As a caveat, it is of course conceivable that many distinctions between Precambrian and Phaerozoic-Modern sedimentation patterns are subtle and remain masked by the overall similitude at the facies to basinal scales. At this point, it is also pertinent to repeat the dictum of Donaldson et al. (2002) that it is really the rates and intensities of processes rather than the nature of the processes that distinguishes the Precambrian period.

Precambrian clastic and carbonate marine deposits are essentially a reflection of a rather unique setting of epeiric seas (both embayments, and the seaways that more strongly resemble shelfal environments), formed due to continental crustal growth processes and rates, especially from the Neoarchaean onwards. Marine deposits outside of this milieu are generally associated with highly deformed inferred ophiolitic successions, some of which are regarded by at least 
portions of the scientific community as controversial. True epeiric sea analogues of any scale are lacking in the current geological record (e.g., Hallam, 1981; Galloway and Hobday, 1983; Pratt and Holmden, 2008), which does not help in modelling of perceived ancient Precambrian clastic equivalents (such as the examples shown in Fig. 11; see also Eriksson et al., 2008b). Microbial mats flourished in the clastic settings of these shallow epeiric basins, and their role in lithofacies (e.g., section 2.7 of this paper) to facies tract (e.g., Sarkar et al., 2005) scale development were likely more pronounced in the Precambrian epoch as opposed to the Phanerozoic, when their role was much reduced through metazoan grazing activity.

Deposition of shallow marine carbonate sediments supports a very distinct difference between Precambrian examples, where biotic mediation to overcome kinetic factors inhibiting direct precipitation of carbonates from seawater was microbial, and the Phanerozoic when skeletal carbonate precipitation was largely mediated through metazoans, algae and protozoans. Molar tooth structure appears to be a unique Precambrian feature, particularly for the MesoNeoproterozoic. However a large degree of uncertainty still hangs over modelling of Precambrian carbonate genesis and is also directly related to ongoing debate and research into palaeo-atmospheric and palaeo-hydrospheric evolution during this epoch.

But, amongst the clastic settings, it is perhaps in the fluvial depositional environment that the greatest potential lies in future study of possibly unique features in Precambrian sedimentation patterns. Their predominantly braided and sandy bed-load style is well researched and equally well ascribable to the lack of vegetation allied to poorly developed soils (e.g., Schumm, 1968; Cotter, 1978; Long, 1978, 2004; Fuller, 1985; Els, 1990; Eriksson et al., 1998). However, temporary and localised ponding of muddy sediment appears to have been a relatively important characteristic of at least some such systems (cf. the Indian and South African examples discussed 
in section 2.2 of this paper; see also, Rainbird, 1992; Eriksson et al., 2006, 2008a). In the case of the examples from the Waterberg Group (South Africa) palaeohydrological data suggest that enhanced palaeoslopes developed locally as a result of ponded muddy sediment, and Eriksson et al. (2009a) relate this to an overall greenhouse palaeo-atmosphere and concomitant strongly episodic (in terms of rainfall) palaeoclimate which may have dominated the Kaapvaal craton from c. $2.3-1.8 \mathrm{Ga}$. Fluvial systems thus have the potential to also impact understanding of the larger issues in Precambrian sedimentation patterns, such as evolution of the extant atmosphere, cratonic and supercontinental geodynamics, palaeoclimates, and the role of microbial organisms. Microbial mats also strongly support episodic channelised flows and distinctly punctuated sedimentation along epeiric coastlines, particularly where large braided fluvial systems debouched into them (cf., Eriksson et al., 2009a).

A distinct potential of future research thus exists in sifting out the commonly subtle evidence of distinctions in sedimentation milieus between the Precambrian and the Phanerozoic. While it might be overly ambitious to claim that an improved comprehension of the evolutionary course of the Earth system as a whole may also eventuate, it might be reasonable to suppose that, at the very least, Precambrian sedimentary studies can contribute to such an enhanced understanding of the planet's history through c. $85 \%$ of its history.

\section{Acknowledgements}

All the authors express gratitude to their respective institutions for infrastructural facilities and research support. SS acknowledges field grants from the CSIR, Government of India and the INSA-DFG for providing a fellowship to work with WA in Munich on molar tooth structure. 
PGE thanks both the University of Pretoria and the National Research Foundation of South Africa for funding. Thino Rajab is acknowledged for drafting many of the figures.

\section{References}

Aitken, J.D., 1991. The Ice Brook Formation and post-Rapitan, late Proterozoic glaciation, Mackenzie Mountains, NW Territories. Geological Survey of Canada Bulletin 404, 43 p.

Alexander, J., Fielding, C.R., 2006. Coarse-grained floodplain deposits in the seasonal tropics: Towards a better facies model. Journal of Sedimentary Research 76(3), 539 - 556.

Allwood, A.C., Walter, M.R., Kamber, B.S., Marshall, C.P., Burch, I.W., 2006. Stromatolite reef from the Early Archaean era of Australia. Nature 441, 714-718.

Altermann, W., 2004. Precambrian stromatolites: problems in definition, classification, morphology and stratigraphy. In: Eriksson, P.G., Altermann, W., Nelson, D.R., Mueller, W.U., Catuneanu, O. (Eds.) The Precambrian Earth: Tempos and Events. Elsevier, Amsterdam, pp. 564-574.

Altermann, W., 2008. Accretion, trapping and binding of sediment in Archean stromatolites-Morphological expression of the antiquity of life. Space Science Review 135, 55-79.

Altermann, W., Siegfried, H.P., 1997. Sedimentology, facies development and type-section of an Archaean shelf-carbonate platform transition, Kaapvaal Craton, as deduced from a deep borehole core at Kathu, South Africa. Journal of African Earth Sciences 24, 391-410.

Altermann, W., Nelson, D.R., 1998. Sedimentation rates, basin analysis and regional correlations of three Neoarchaean and Palaeoproterozoic sub-basins of the Kaapvaal craton as inferred from precise U-Pb zircon ages from volcaniclastic sediments. Sedimentary Geolology 120, 225-256.

Altermann, W., Corcoran, P.L., 2002a. Precambrian Sedimentary Environments: A Modern Approach to Ancient Depositional Systems. Blackwell, Oxford, 450 p.

Altermann, W., Corcoran, P.L., 2002b. Introduction. In: Altermann W., Corcoran, P.L. (Eds.) Precambrian Sedimentary Environments: A Modern Approach to Ancient Depositional Systems. Blackwell, Oxford, pp. vii-xi. 
Altermann, W., Kazmierczak, J., Oren, A., Wright, D., 2006. Microbial calcification and its impact on the sedimentary rock record during 3.5 billion years of Earth history. Geobiology 4, 147-166.

Amieux, P., 1982. La cathodoluminescence: méthode d'étude sédimentologique des carbonates. Bull. Cent. Rech. Explor. Prod. Elf-Aquitaine 6, 437-483.

Amthor, J. E., Grotzinger, J. P., Schröder, S; Bowring, S. A., Ramezani, J., Martin, M. W., Matter, A., 2003. Extinction of Cloudina and Namacalathus at the Precambrian-Cambrian boundary in Oman. Geology 31 431-434.

Andersson, A.J., Mackenzie, F.T., Ver, L.M., 2003. Solution of shallow-water carbonates: An insignificant buffer against rising atmospheric $\mathrm{CO}_{2}$. Geology $31(6)$, 513-516.

Aspler, L.B., Chiarenzelli, J.R., 1998. Two Neoarchean supercontinents? Evidence from the Paleoproterozoic. Sedimentary Geology 120, 75-104.

Aspler, L.B., Bursey, T.L., LeCheminant, A.N., 1992. Geology of the Henik, Montgomery Lake and Hurwitz groups in the Bray-Montgomery-Ameto lakes area, southern District of Keewatin, Northwest Territories. Geological Survey of Canada, Paper 92-1C, Current Research Part C, pp. 157-170.

Aspler, L.B., Chiarenzelli, J.R., Bursey, T.L., 1994. Ripple marks in quartz arenites of the Hurwitz Group, Northwest Territories, Canada: evidence for sedimentation in a vast, Early Proterozoic, shallow, freshwater lake. Journal of Sedimentary Research A 64(2), 282-298.

Awramik, S.M., Sprinkle, J., 1909. Proterozoic stromatolites; the first marine evolutionary biota. Historical Biology 13, 241-253.

Babinski, M., Chemale, F. Jr., Van Schmus, W.R., 1995. The Pb/Pb age of the Minas Supergroup carbonate rocks, Quadrilátero Ferrífero, Brazil. Precambrian Research 72, 235-245.

Banerjee, S., Jeevankumar, S., 2005. Microbially originated wrinkle structures on sandstones and their stratigraphic context. Paleoproterozoic Koldaha Shale, central India. Sedimentary Geology 176, 211-224.

Bauerman, H., 1885. Report on the geology of the country near the forty-ninth parallel of north latitude west of the Rocky Mountains. Geological Survey of Canada Report, 1882-83-84, pt. B, pp 1-42.

Bekker, A., Eriksson, K.A., 2003. Paleoproterozoic drowned carbonateplatform on the southeastern margin of the Wyoming Craton: a record of the Kenorland breakup. Precambrian Research 120, 327-364.

Bekker, A., Kaufman, A.J., Karhu, J.A., Beukes, N.J., Swart, Q.D., Coetzee, L.L., Eriksson, K.A., 2001. 
Chemostratigraphy of the Paleoproterozoic Duitschland Formation, South Africa: implications for coupled climate change and carbon cycling. American Journal of Science 301, 261-285.

Bekker, A., Holmden, C., Patterson, W., Eglington, B., Coetzee, L. L., Beukes, N., 2004 Chemostratigraphy Of Early Paleoproterozoic carbonates of South Africa. Denver Annual Meeting, Paper No. 142-12.

Bekker, A., Kaufman, A.J., Karhu, J.A., Eriksson, K.A., 2005. Evidence for Paleoproterozoic cap carbonates in North America. Precambrian Research 137, 167-206.

Bell, R.T., 1966. Precambrian rocks of the Tuchodi Lakes map-area, northeastern British Columbia, Canada. Unpublished Ph.D. thesis, Princeton University, 138 p.

Bengtson, S., 1994. Early life on Earth. Nobel Symposium no. 84: New York, Columbia University Press, 630 p. Bertrand-Sarfati, J., Moussine-Pouchkine, A., 1988. Is cratonic sedimentation consistent with available models? An example from the upper Proterozoic of the West African craton. Sedimentary Geology 58, 255-276.

Beukes, N.J., 1987. Facies relations, depositional environments and diagenesis in a major Early Proterozoic stromatolitic carbonate platform to basinal sequence, Campbellrand Subgroup, Transvaal Supergroup, Southern Africa. Sedimentary Geolology 54, 1-46.

Beukes, N.J., 1996. Sole marks and combined-flow storm event beds in the Brixton Formation of the siliciclastic Archean Witwatersrand Supergroup, South Africa. Journal of Sedimentary Research 66, 567-576.

Beukes, N.J., Cairncross, B., 1991. A lithostratigraphic-sedimentological reference profile for the Late Archaean Mozaan Group, Pongola Sequence: application to sequence stratigraphy and correlation with the Witwatersrand Supergroup. South African Journal of Geology 94, 44-69.

Beukes, N.J., Lowe, D.R., 2006. Environmental control on diverse stromatolite morphologies in the $3000 \mathrm{Myr}$ Pongola Supergroup, South Africa. Sedimentology 36, 383-397.

Bibikova, E.V., 2010. Isotope-geochemical constraints on the formation of the early Earth crust. Petrology 18 (5), $482-488$.

Bishop, J.W., Sumner, D.Y., Huerta, N.J., 2006. Molar tooth structures of the Neoarchean Monteville Formation, Transvaal Supergroup, South Africa. II: a wave-induced fluid flow model. Sedimentology 53, 1069-1082.

Blair, T.C., McPherson, J.G., 1994. Alluvial fans and their natural distinction from rivers based on morphology, hydraulic processes, sedimentary processes, and facies assemblages. Journal of Sedimentary Research A64, 450-489. 
Blum, M.D., Tornqvist, T.E., 2000. Fluvial responses to climate and sea-level change: a review and look forward. Sedimentology 47 (suppl. 1), 2-48.

Bodiselitsch, B., Koeberl, C., Master, S., Reimold, W.U., 2005. Estimating duration and intensity of Neoproterozoic snowball glaciations from Ir anomalies. Science 308, 239-242.

Bose, P.K., Chakraborty, P.P., 1994. Marine to fluvial transition: Proterozoic Upper Rewa Sandstone, Maihar, India. Sedimentary Geology 89, 285-302.

Bose, P.K., Chaudhuri, A.K., Seth, A., 1988. Facies, flow and bedform patterns across a storm-dominated inner continental shelf: Proterozoic Kaimur Formation, Rajasthan, India. Sedimentary Geology 59, 275-293.

Bose, P.K., Chakraborty, S., Sarkar, S., 1999. Recognition of ancient eolian longitudinal dunes: a case study in Upper Bhander Sandstone, Son Valley, India. Journal of Sedimentary Research 69, 86-95.

Bose, P.K., Sarkar, S., Chakrabarty, S., Banerjee, S., 2001. Overview of the Meso- to Neoproterozoic evolution of the Vindhyan basin, central India. Sedimentary Geology 141-142, 395-419.

Bosnak, T, Newman, D.K., 2003. Microbial nucleation of calcium carbonate in the Precambrian. Geology 31, 577580.

Bottjer, D., Hagadorn, J.W., 2007. Mat Growth Features. In: Schieber, J., Bose, P.K., Eriksson, P.G., Banerjee, S., Sarkar, S., Altermann, W., Catuneanu, O. (Eds.) Atlas of microbial mat features preserved within the Siliciclastic rock record. Atlases in Geoscience 2. Elsevier, Amsterdam, pp. 53-71.

Bouma, A.H., 1962. Sedimentology of some Flysch Deposits. Elsevier, Amsterdam, 168 p.

Bouougri, E., Porada, H., 2002. Mat related sedimentary structures in Neoproterozoic peritidal passive margin deposits of the West African Craton. Sedimentary Geology 153, 85-106.

Brasier, M.D., Green, O.R., Lindsay, J.F., Steele, A., 2004. Earth's oldest (approximately 3.5 Ga) fossil and the "Early Eden hypothesis": Questioning the evidence. Origins of Life and Evolution of the Biosphere 34, 257-269.

Brenner, R.L., 1980. Construction of processes-response models for ancient epicontinental seaway depositional systems using partial analogs. American Association of Petroleum Geologists Bulletin 64, 1223-1244.

Brookfield, M.E., 1977. The origin of bounding surfaces in ancient aeolian sandstone. Sedimentology 24, 303-332.

Brookfield, M.E., 1994. Problems in applying preservation, facies and sequence models to Sinian (Neoproterozoic) glacial sequences in Australia and Asia. Precambrian Research. 70, 113-143. 
Buck, S.G., Minter, W.E.L., 1985. Placer formation by fluvial degradation of an alluvial fan sequence: the Proterozoic Carbon Leader Placer, Witwatersrand Supergroup, South Africa. Journal of the Geological Society, London 142, 757-764.

Buck, R., Dunlop, J.S.R., 1990. Evaporitic sediments of Early Archaean age from theWarrawoona Group, North Pole, Western Australia. Sedimentology 37, 247 - 277.

Buick, I.S., Uken, R., Gibson, R.L., Wallmach, T., 1998. High- $\delta 13 \mathrm{C}$ Paleoproterozoic carbonates from the Transvaal Supergroup, South Africa. Geology 26, 875-878.

Buick, R., Des Marais, D. J., Knoll, A. H., 1995. Stable isotopic compositions of carbonates from the Mesoproterozoic Bangemall Group, northwestern Australia. Chemical Geology 123, 153-171.

Bumby, A.J., 2000. The geology of the Blouberg Formation, Waterberg and Soutpansberg Groups in the area of Blouberg Mountain, Northern Province, South Africa. Unpublished Ph.D. Thesis, University of Pretoria, Pretoria, $325 \mathrm{p}$.

Bumby, A.J., Eriksson, P.G., van der Merwe, R., Maier, W., 2001. The stratigraphic relationship between the Waterberg Group and the Soutpansberg Group (Northern Province, South Africa): Evidence from the Blouberg area. South African Journal of Geology 104, 105-216.

Burke, K., Kidd, W.S.F., Kusky, T.M., 1986. Archean foreland basin tectonics in the Witwatersrand, South Africa. Tectonics 5, 439-456.

Burns, S.J., Matter, A., 1993. Carbon isotopic record of the latest Proterozoic from Oman. Eclogae Geologia Helveticae 86, 595-607.

Burns S.J., McKenzie, J.A., Vasconcelos, C., 2000. Dolomite formation and biogeochemical cycles in the Phanerozoic. Sedimentology 47 (Supp. 1), 49-61.

Byerly, G.R., Lowe, D.R., Walsh, M.M., 1986. Stromatolites from the 3300 - 3500 Myr Swaziland Supergroup, Barberton Mountain Land, South Africa. Nature 319, 489-491.

Callaghan, C.C., Eriksson, P.G., Snyman, C.P., 1991. The sedimentology of the Waterberg Group in the Transvaal, South Africa: An overview. Journal of African Earth Sciences 13, 121-139.

Calver, C.R., Baillie, P.W., 1990. Early diagenetic concretions associated with intrastratal shrinkage cracks in an upper Proterozoic dolomite, Tasmania, Australia. Journal of Sedimentary Petrology 60, 293-305.

Canfield D.E., Raiswell R., 1991. Carbonate precipitation and dissolution. Its relevance to fossil preservation. In: 
Allison, P.A, Briggs, D.E.G, (Eds.) Taphonomy: Releasing the Data in the Fossil Record. Plenum Press, London, pp 412-453.

Castanier, S., Le Métayer-Levrel, G., Perthuisot, J.P. 1999. Ca-carbonates precipitation and limestone genesis - the microbiologist point of view. Sedimentary Geology 126(1-4), 9-23.

Catuneanu, O., 2001. Flexural partitioning of the Late Archaean Witwatersrand foreland system, South Africa. Sedimentary. Geology 141-142, 95-112.

Catuneanu, O., 2004. Retroarc foreland systems - evolution through time. Geological Society of Africa Presidential Review No. 7, Journal of African Earth Sciences 38, 225-242.

Catuneanu, O., 2006. Principles of Sequence Stratigraphy, Elsevier, Amsterdam, 375p.

Catuneanu, O., Eriksson, P.G., 1999. The sequence stratigraphic concept and the Precambrian rock record: an example from the 2.3-2.1 Ga Pretoria Group, Kaapvaal craton. Precambrian Research 97, 215-251.

Catuneanu, O., Eriksson, P.G., 2002. Sequence stratigraphy of the Precambrian Rooihoogte-Timeball Hill rift succession, Transvaal Basin, South Africa. Sedimentary Geology 147, 71-88.

Catuneanu, O., Eriksson, P.G. 2007. Sequence stratigraphy of the Precambrian. Gondwana Research. 12, 560565.

Chakraborty, C., Bose, P.K., 1992. Rhythmic shelf storm beds: Proterozoic Kaimur Formation, India. Sedimentary Geology 77, 259-268.

Chakraborty, P.P., 1995. Facies and sequence development in some Late Proterozoic Formations in Son-valley, India with some clues for basin evolution. Unpublished Ph.D. thesis, Jadavpur University, India, 104p.

Chakraborty, S., 2002. Sedimentation sequence of the three youngest members of the Vindhyan Supergroup, central India. Unpublished Ph.D. thesis, Jadavpur University, India, 150p.

Chakraborty, T., Sarkar, S., Chaudhury, A.K., Das Gupta, S., 1996. Depositional environment of Vindhyan and other Purana Basins: A reappraisal in the light of recent findings. Geological Society of India, Memoir 36, 101-126.

Chauhan, D.S., 1999. Tectonic and sedimentary evolution of the Marwar basin: A Neoproterozoic-Early Cambrian intracratonic sag basin. In: Kataria, P. (Ed.) Proceedings of the seminar on Geology of Rajasthan-status and perspective (A. B. Roy Felicitation Volume). Geology Department, MLSU, Udaipur, pp. 111-125.

Chauhan, D.S., Ram, B., 1999. Ripple marks and synthesis of beach sequences: A study of early Palaeozoic 
Jodhpur Sandstone, western Rajasthan, In: Palliwal, B.S. (Ed.) Geological evolution of northwestern India. Scientific Publications, India, pp. 129-147.

Chen, D.F., Dong, W.Q., Zhu, B.Q., Chen, X.P., 2004. Pb-Pb ages of Neoproterozoic Doushantuo phosphorites in South China: constraints on early metazoan evolution and glaciation events. Precambrian Research 132, $123-132$.

Choquette, P.W., 1968. Marine diagenesis of shallow marine lime-mud sediments: Insights from $\mathrm{O}^{18}$ and $\mathrm{C}^{13}$ data. Science 161, 1130-1132.

Clemmensen, L.B., Abrahamsen, K., 1983. Aeolian stratification and facies associations in desert sediments, Arran Basin (Permian), Scotland. Sedimentology 30, 311-339.

Clemmenson, L.B., Dam, G., 1993. Aeolian sand sheet deposits in the lower Cambrian Neksø Sandstone Formation, Bornholm, Denmark: sedimentary architecture and genesis. Sedimentary Geology 83, 71-85.

Condie, K.C., 1997. Plate Tectonics and Crustal Evolution, 4th ed. Butterworth Heinemann, Oxford, 282p.

Condie, K.C., Des Marais, D.J., Abbott, D., 2001. Precambrian superplumes and supercontinents: a record in black shales, carbon isotopes, and paleoclimates? Precambrian Research 106, 239-260.

Condon, D., Zhu, M., Bowring, S., Wang, W., Yang, A., Jin, Y., 2005. U-Pb ages from the Neoproterozoic Doushantuo Formation, China. Science 308, 95-98.

Coniglio, M., 1986. Synsedimentary submarine slope failure and tectonic deformation in deep water carbonates, Cow Head Group, Western Newfoundland. Canadian Journal of Earth Science 23, 476-490.

Corcoran, P.L., Mueller, W.U. 2004. Archaean sedimentary sequences. In: Eriksson, p.g., Altermann, W., Nelson, D.R., Mueller, W.U., Catuneanu, O. (Eds.) The Precambrian Earth: tempos and events. Elsevier, Amsterdam, pp. 613-625.

Corcoran, P.L., Mueller, W.U., Chown, E.H., 1998. Climatic and tectonic influences on fan deltas and wave- to tide-controlled shoreface deposits: evidence from the Archaean Keskarrah Formation, Slave Province, Canada. Sedimentary Geology 120, 125-152.

Corkeron, M.L., George, A.D., 2001. Glacial inclusion on a Neoproterozoic carbonate platform in the Kimberley region, Australia. Geological Society America Bulletin 113, 1121-1132.

Cornell, D.H., Schutte, S.S., Eglington, B.L., 1996. The Ongeluk Basaltic Andesite Formation in Griqualand West, South Africa: Submarine alteration in a 2222 Ma Proterozoic sea. Precambrian Research 79, 101- 
124.

Cotter, E., 1978. The evolution of fluvial style, with special reference to the central Appalachian Palaeozoic. In: Miall, A.D. (Ed.) Fluvial Sedimentology. Memoir, Canadian Society of Petroleum Geologists, Calgary, Alberta, Canada, 5, pp. 361-383.

Cowan, C.A., James, N.P., 1992. Diastasis cracks: mechanically generated synaeresis-like cracks in Upper Cambrian shallow water oolite and ribbon carbonates. Sedimentology 39, 1101-1118.

Daly, R.A., 1912. Geology of the North American Cordillera at the forty-ninth parallel. Geological Survey of Canada Memoir 38.

Demicco, R.V., Hardie, L.A., 1994. Sedimentary Structures and Early Diagenetic Features of Shallow Marine Carbonate Deposits. Society of Economic Paleontologists and Mineralogists, Tulsa, Oklahoma, Atlas Series 1, 68-71.

De Wit, M.J., Roering, C., Hart, R.J., Armstrong, R.A., De Ronde, R.E.J., Green, R.W.E., Tredoux, M., Perberdy, E., Hart, R.A., 1992. Formation of an Archaean continent. Nature 357, 553-562.

Des Marais, D.J., 1994. The Archean atmosphere: its composition and fate. In: Condie, K.C. (Ed.) Archean Crustal Evolution. Developments in Precambrian Geology 11, Elsevier, Amsterdam, pp. 505-519.

Desrochers, A., Al-Assm, I.S., 1993. The formation of septarian concretions in Queen Charlotte Islands, B.C.: evidence for microbially and hydrothermally mediated reactions at shallow burial depth. Journal of Sedimentary Petrology 63, 282-294.

Dill, R.F., Shinn, E.A., Jones, A.T., Kelly, K., Steinen, R.P., 1986. Giant subtidal stromatolites forming in normal salinity waters. Nature 324, 55-58.

Dix, G.R., Mullins, H.T., 1987. Shallow, subsurface growth and burial alteration of Middle Devonian calcite concretions. Journal of Sedimentary Petrology 57, 140-152.

Donaldson, J.A., de Kemp, E.A., 1998. Archaean quartz arenites in the Canadian Shield: examples from the Superior and Churchill Provinces. Sedimentary Geology 120, 153-176.

Donaldson, J.A., Eriksson, P.G., Altermann, W., 2002. Actualistic versus non-actualistic conditions in the Precambrian: a reappraisal of an enduring discussion. In: Altermann, W., Corcoran, P.L. (Eds.) Precambrian Sedimentary Environments: a modern approach to ancient depositional systems. Blackwell, Oxford, I.A.S. special publication 33, pp. 3-13. 
Donnelly, T.H., Crick, I.H., 1988. Depositional environment of the Middle Proterozoic Velkerri Formation in northern Australia: geochemical evidence. Precambrian Research 42, 165-172.

Douglas, S., Beveridge, T.J., 1998. Mineral formation by bacteria in natural microbial communities. FEMS Microbiology Ecology 26(2), 79-88.

Eby, D.E., 1977. Sedimentation and early diagenesis within eastern portions of the 'middle Belt carbonate interval' (Helena Formation), Belt Supergroup (Precambrian), western Montana. Unpublished Ph.D. thesis, State University of New York, Stony Brook, NY, 504p.

Eglington, B.M., Armstrong, R.A., 2004. The Kaapvaal Craton and adjacent orogens, southern Africa: a geochronological database and overview of the geological development of the craton. South African Journal of Geology 107, 13-32.

Els, B.G., 1990. Determination of some palaeohydraulic parameters for a fluvial Witwatersrand succession. South African Journal of Geology 93, 531-537.

Els, B.G., 1998. The auriferous Late Archaean sedimentation systems of South Africa: unique palaeoenvironmental conditions? Sedimentary Geology 120, 205-224.

Els, B.G., Mayer, J.J., 1993. Authors' reply to discussion by P.G. Eriksson et al. of: Els, B.G., Mayer, J.J., Transgressive and progradational beach and nearshore facies in the Late Archaean Turffontein Subgroup of the Witwatersrand Supergroup, Vredefort Area, South Africa. South African Journal of Geology 96, 62.

Els, B.G., Mayer, J.J., 1998. Coarse clastic tidal and fluvial sedimentation during a large late Archean sea-level rise: the Turffontein Subgroup in the Vredefort Structure, South Africa. In: Alexander, C.W., Davis, R.A., Henry, V.J. (Eds.) Tidalites: Processes and Products. Society of Economic Paleontologists and Mineralogists, Tulsa, Oklahoma, Special Publications 61, pp. 155-165.

Eriksson, K.A., 1979. Marginal marine depositional processes from the Archaean Moodies Group, Barberton Mountain Land, South Africa: Evidence and significance. Precambrian Research 8, 153-182.

Eriksson, K.A., Turner, B.R., Vos, R.G., 1981. Evidence of tidal processes from the lower part of the Witwatersrand Supergroup, South Africa. Sedimentary Geology 29, 309-325.

Eriksson, P.G., Cheney, E.S., 1992. Evidence for the transition to an oxygen-rich atmosphere during the evolution of red beds in the Lower Proterozoic sequences of southern Africa: Precambrian Research 54, 257-269.

Eriksson, P.G., Altermann, W., 1998. An overview of the geology of the Transvaal Supergroup dolomites (South 
Africa). Environmental Geology 36, 179-188.

Eriksson, P.G., Reczko, B.F.F., 1998. Contourites associated with pelagic mudrocks and distal delta-fed turbidites in the Lower Proterozoic Timeball Hill Formation epeiric basin (Transvaal Supergroup), South Africa. Sedimentary Geology 120, 319-335.

Eriksson, K.A., Simpson, E.L., 1998. Controls on spatial and temporal distribution of Precambrian aeolianites. Sedimentary Geology 120, 275-294.

Eriksson, P.G., Catuneanu, O., 2004a. Third-order sequence stratigraphy in the Palaeoproterozoic Daspoort Formation (Pretoria Group, Transvaal Supergroup), Kaapvaal craton. In: Eriksson, P.G., Altermann, W., Nelson, D.R., Mueller, W.U., Catuneanu, O. (Eds.) The Precambrian Earth: tempos and events. Elsevier, Amsterdam, pp. 724-735.

Eriksson, P.G., Catuneanu, O., 2004b. A commentary on Precambrian plate tectonics. In: Eriksson, P.G., Altermann, W., Nelson, D.R., Mueller, W.U., Catuneanu, O. (Eds.) The Precambrian Earth: tempos and events. Elsevier, Amsterdam, pp. 201-213.

Eriksson, P.G., Reczko, B.F.F., Boshoff, A.J., Schreiber, U.M., Van der Neut, M., Snyman, C.P., 1995. Architectural elements from Lower Proterozoic braid-delta and high-energy tidal flat deposits in the Magaliesberg Formation, Transvaal Supergroup, South Africa. Sedimentary Geology 97, 99-117.

Eriksson, P.G., Reczko, B.F.F., Corner, B., Jenkins, S.L., 1996. The Kanye axis, Kaapvaal craton, southern Africa: a postulated Archaean crustal architectural element inferred from three-dimensional basin modelling of the lower Transvaal Supergroup. Journal of African Earth Sciences 22, 223-233.

Eriksson, P.G., Condie, K.C., Tirsgaard, H., Mueller, W.U., Altermann, W., Miall, A.D., Aspler, L.B., Catuneanu, O., Chiarenzelli, J.R., 1998. Precambrian clastic sedimentation systems. Sedimentary. Geology., 120, 5-53.

Eriksson, P.G., Simpson, E.L., Eriksson, K.A., Bumby, A.J., Steyn, G.L., Sarkar, S., 2000. Muddy roll-up structures in siliciclastic interdune beds of the c. 1.8 Ga Waterberg Group, South Africa. Palaios 15, 177-183.

Eriksson, P.G., Martins-Neto, M.A., Nelson, D.R., Aspler, L.B., Chiarenzelli, J.R., Catuneanu, O., Sarkar, S., Altermann, W., Rautenbach, C.J.deW., 2001a. An introduction to Precambrian basins: their characteristics and genesis. Sedimentary Geology 141-142, 1-35.

Eriksson, P.G., Altermann, W., Catuneanu, O., van der Merwe, R., Bumby, A.J., 2001b. Major influences on the evolution of the 2.67-2.1 Ga Transvaal basin, Kaapvaal craton. Sedimentary Geology 141-142, 205-231. 
Eriksson, P.G., Altermann, W., Eberhardt, L., Ahrend-Heidbrinck, S., Bumby, A.J., 2002. Palaeoproterozoic epeiric sea palaeoenvironments: the Silverton Formation (Pretoria Group, Transvaal Supergroup), South Africa. In: Altermann, W., Corcoran, P.L. (Eds.) Precambrian Sedimentary Environments: a modern approach to ancient depositional systems. Blackwell, Oxford, Special Publication of the International Association of Sedimentologists 33, pp. 351-368.

Eriksson, P.G., Altermann, W., Nelson, D.R., Mueller, W.U., Catuneanu, O. (Eds.) 2004a. The Precambrian Earth: tempos and events. Elsevier, Amsterdam, 941p.

Eriksson, P.G., Bumby, A.J., Popa, M., 2004b. Introduction, Chapter 7. In: Eriksson, P.G., Altermann, W., Nelson, D.R., Mueller, W.U., Catuneanu, O. (Eds.) The Precambrian Earth: tempos and events. Elsevier, Amsterdam, pp. 593-602.

Eriksson, P.G., Bose, P.K., Sarkar, S., Banerjee, S., 2004c. Sedimentation rates. In: Eriksson, P.G., Altermann, W., Nelson, D.R., Mueller, W.U., Catuneanu, O. (Eds.) The Precambrian Earth: tempos and events. Elsevier, Amsterdam, pp. 675-677.

Eriksson, P.G., Bumby, A.J., Mostert, P., 2004d. Early Precambrian epeiric seas. In: Eriksson, P.G., Altermann, W., Nelson, D.R., Mueller, W.U., Catuneanu, O. (Eds.) The Precambrian Earth: Tempos and Events. Elsevier, Amsterdam, pp. 657-660.

Eriksson, P.G., Catuneanu, O., Sarkar, S., Tirsgaard, H., 2005. Patterns of sedimentation in the Precambrian. Sedimentary Geology 176, 17-42.

Eriksson, P.G., Bumby, A.J., Brümer, J.J., van der Neut, M., 2006. Precambrian fluvial deposits: Enigmatic palaeohydrological data from the c. 2-1.9 Ga Waterberg Group, South Africa. Sedimentary Geology 190, 25-46.

Eriksson, P.G., Banerjee, S., Catuneanu, O., Sarkar, S., Bumby, A.J., Mtimkulu, M.N., 2007. Prime controls on Archaean-Palaeoproterozoic sedimentation: Change over time. Gondwana Research 12, 550-559.

Eriksson, P.G., Long, D.G.F., Bumby, A.J., Eriksson, K.A., Simpson, E.L., Catuneanu, O., Claassen, M., Mtimkulu, M.N., Mudziri, K., Brümer, J., van der Neut, M., 2008a. Palaeohydrological data from the c. 2.0 to $1.8 \mathrm{Ga}$ Waterberg Group, South Africa: discussion of a possibly unique Palaeoproterozoic fluvial style. South African Journal of Geology 111/2-3, 281-304.

Eriksson, P.G., Bose, P.K., Catuneanu, O., Sarkar, S., Banerjee, S., 2008b. Precambrian clastic epeiric embayments: 
examples from South Africa and India. In: Pratt, B.R., Holmden, C. (Eds.) Dynamics of epeiric seas. Special Paper, Geological Association of Canada 48, St. Johns, Newfoundland, pp. 119-136.

Eriksson, P.G., Rautenbach, C.J.deW., Wright, D.T., Bumby, A.J., Catuneanu, O., Mostert, P., van der Neut, M., 2009a. Possible evidence for episodic epeiric marine and fluvial sedimentation (and implications for palaeoclimatic conditions), c. 2.3-1.8 Ga, Kaapvaal craton, South Africa. Palaeogeography, Palaeoclimatology, Palaeoecology 273, 153-173.

Eriksson, P.G., Banerjee, S., Nelson, D.R., Rigby, M.J., Catuneanu, O., Sarkar, S., Roberts, R.J., Ruban, D., Mtimkulu, M.N., Sunder Raju, P.V., 2009b. A Kaapvaal craton debate: nucleus of an early small supercontinent or affected by an enhanced accretion event? Gondwana Research 15, 354-372.

Eriksson, P.G., Sarkar, S., Samanta, P., Banerjee, S., Porada, H., Catuneanu, O., 2010. Palaeoenvironmental context of microbial mat related structures in siliciclastic rocks: Examples from the Proterozoic of India and South Africa, In: Seckbach, J., Oren, A. (Eds.) Modern and Ancient Microorganisms in Stratified Systems. Springer, Berlin, pp. 71-108.

Eriksson, P.G., Catuneanu, O., Nelson., D.R., Altermann, W., Rigby, M.J., 2011. Events in the Precambrian history of the Earth: problems in the definition of globally significant events and in their identification within the rock record. Journal of Marine and Petroleum Geology, this volume.

Evans, D.A., Beukes, N.J., Kirschvink, J.L., 1997. Low-latitude glaciation in the Paleoproterozoic era. Nature 386, 262-266.

Eugster, H.P., 1986. Lake Magadi, Kenya: a model for rift valley hydrochemistry and sedimentation? In: Frostick, L.E., Renaut, R.W., Reid, I., Tiercelin, J.J. (Eds.) Sedimentation in the African Rifts. Geological Society Special Publication 25, 177-189.

Fagerstrom, J.A., 1967. Development, foliation and transportation of mud crusts- neglected factors in Sedimentology: Journal of Sedimentary Petrology 37, 73-79.

Fairchild, I.J., Hambrey, M.J., 1984. The Vendian succession of northeastern Spitsbergen: Petrogenesis of a dolomite-tillite association. Precambrian Research 26, 111-167.

Fairchild, I. J., Einsele, G., Song, T., 1997. Possible seismic origin of molar tooth structures in Neoproterozoic carbonate ramp deposits, north China. Sedimentology 44, 611-636.

Fairchild, I.J., Spiro, B., Herrington, P.M., Song, T., 2000. Controls on Sr and C isotope compositions of 
Neoproterozoic Sr-rich limestones of E. Greenland and N. China. In: Grotzinger, J.P., James, N.P. (Eds.) Carbonate Sedimentation and Diagenesis in the Evolving Precambrian World. Special Publication, Society of Economic Paleontologists and Mineralogists, Tulsa, Oklahoma, 67, pp. 297-313.

Fedo, C.M., Myers, J.S., Appel, P.W.U., 2001. Depositional setting and paleogeographic implications of earth's oldest supracrustal rocks, the $>3.7$ Ga Isua Greenstone belt, West Greenland. Sedimentary Geology 141$142,61-77$.

Feldman, M., Mackenzie, J., 1998. Stromatolite-thrombolite association in a modern environment, Leestocking Island, Bahamas. Palaios 134, 201-212.

Fischer, A.G., 1965. Fossils, early life, and atmospheric history. Proceedings of the National Academy of Science $53,1205-1215$.

Foriel, J., Philippot, P., Rey, P., Somogyi, A., Banks, D., Ménez, B., 2004. Biological control of Cl/Br and low sulfate concentration in a 3.5-Gyr-old seawater from North Pole, Western Australia. Earth and Planetary Science Letters 228, 451-463.

Fracasso, M.A., Hovorka, S.D., 1986. Cyclicity in the middle Permian San Andres Formation, Palo Duro Basin, Texas Panhandle. Bureau of Economic Geology Repository of Investigations. University of Texas, 48p. Frank, T.D., Lyons, T.W., 1998. 'Molar-tooth' structures: a geochemical perspective on a Proterozoic enigma. Geology 26, 683-686.

Friedman, G.M., Sanders, J.E., 1974. Positive-relief bedforms on modern tidal-flats that resemble molds of flutes and grooves: implications for geopetal criteria and for origin and classification of bedforms. Journal of Sedimentary Petrology 44, 181-189.

Friedman, G.M., Sanders, J.E., Kopaska-Merkel, D.C., 1992. Principles of Sedimentary Deposits. Macmillan, New York, $717 \mathrm{p}$.

Frimmel, H.E., Fölling, P.G., Eriksson, P.G., 2002. Neoproterozoic tectonic and climatic evolution recorded in the Gariep Belt, Namibia and South Africa. Basin Research 14, 55-67.

Fryberger, S.G., Ahlbrandt, T.S., Andrews, S., 1979. Origin, sedimentary features of low-angle eolian 'sand sheet' deposits, Great Sand Dunes National Monument and vicinity, Colorado. Journal of Sedimentary Petrology 49, 733-746.

Fryberger, S.G., Schenk, C.J., Hesp, P., 1988. Pin stripe lamination; a distinctive feature of modern and ancient 
eolian sediments. Sedimentary Geology 55, 1-15.

Fryberger, S.G., Hesp, P., Hastings, K., 1992. Aeolian granule ripple deposits, Namibia. Sedimentary Geology 39, 319-333.

Fuller, A.O., 1985. A contribution to the conceptual modelling of pre-Devonian fluvial systems. Transactions of the Geological Society of South Africa 88, 189-194.

Furniss, G., Rittel, J.F., Winston, D., 1994. Gas bubble and expansion crack origin of molar-tooth calcite structures in the Middle Proterozoic Belt Supergroup, Western Montana. Northwest Geology 23, 92-96.

Furniss, G., Rittel, J.F., Winston, D., 1997. Gas bubble and expansion crack origin of 'molar-tooth' calcite structures in the Middle Proterozoic Belt Supergroup, western Montana. Journal of Sedimentary Research $68,104-114$.

Galimov, E.M., Migdisov, A.A., Ronov, A.B., 1975. Variation in the isotopic composition of carbonate and organic carbon in sedimentary rocks during Earth's history. Geochemistry International 12, 1-19.

Galloway, W.E., Hobday, D.K., 1983. Terrigenous clastics depositional systems. Springer, New York, 423p.

Gandin, A., Wright, D. T., 2007. Evidence of vanished evaporites in Neoarchaean carbonates of South Africa. In: Schreiber, B. C., Lugli, S., Babel, M. (Eds.) Evaporites through Space and Time. Geological Society, Special Publication 285, pp. 341-364.

Gandin, A., Wright, D. T., Melezhik, V., 2005. Vanished evaporites and carbonate formation in the Neoarchaean Kogelbeen and Gamohaan Formations of South Africa. Presidential Review 8, Journal of African Earth Sciences 41, 1-23.

Garcia-Ruiz, J.M., Hyde, S.T., Carnerup, A.M., Christy, A.G., van Krankendonk, M.J., Welham, N.J., 2003. Selfassembled silica-carbonate structures and detection of ancient microfossils. Science 302, 1194-1197.

Garrels,R .M., Christ, C.L., 1965. Solution, minerals and equilibria. Harper and Row, New York, 450p.

Gehling, J.G., 1999. Microbial mats in the terminal Proterozoic siliciclastics: Ediacaran death masks. Palaios 14, 4057.

Gerdes, G., Klenke, T., 2003. Geologische Bedeutung ökologischer Zeiträume in biogener Schichtung (Mikrobenmatten, potentielle Stromatolithe). Mitteilungen des Gesellschaft Geologische Bergbaustudien Österreich 46, 35-49.

Gerdes, G., Klenke, T., 2007. States of biogenic bedding as records of the interplay of ecologic time and 
environment (a case study of modern siliciclastic sediments, Mellum Island, southern North Sea). Senckenbergia Maritima 37/2, 129-144.

Gerdes, G., Claes, M., Dunajtschik-Piewak, K., Krumbein, W.E., Reineck, H-E., 1993. Contribution of microbial mats to sedimentary surface structures. Facies $29,61-74$.

Gerdes, G., Klenke, T., Noffke, N., 2000. Microbial signatures in peritidal siliciclastic sediments: a catalogue. Sedimentology 47, 279-308.

Golubic S., Browne, K., 1996. Schizothrix gebelenii sp. nova builds subtidal stromatolites, Lee Stocking Island, Bahamas. Algolog Stud. 83, 273-290.

Grassineau, N.V., Nisbet, E.G., Bickle, M.J., Fowler, C.M.R., Lowry, D., Mattey, D.P., Abell, P., Martin, A., 2001. Antiquity of the biological sulphur cycle: evidence from sulphur and carbon isotopes in 2700 million-yearold rocks of the Belingwe Belt, Zimbabwe. Biological Science 268, 1471-2954.

Grassineau, N.V., Nisbet, E.G., Fowler, C.M.R., Bickle, M. J., Lowry, D., Chapman, H.J., Mattey, D.P., Abell, P., Yong, J., Martin, A., 2002. Stable isotopes in the Archaean Belingwe belt, Zimbabwe: evidence for a diverse microbial mat ecology. In: Fowler, C.M.R., Ebinger, C.J., Hawkesworth, C.J. (Eds.) The Early Earth: Physical, Chemical and Biological Development. Geological Society Special Publication 199, pp. $309-328$.

Grotzinger, J.P., 1989. Facies and evolution of Precambrian carbonate depositional systems: emergence of the modern platform archetype. In: Crevello, P.D., Wilson, J.L., Sarg, J.F., Read, J.F. (Eds.) Controls on Carbonate Platform and Basin Development. Society of Economic Paleontologists and Mineralogists Special Publication 44, Tulsa, Oklahoma, pp. 79-101.

Grotzinger, J.P., 1994. Trends in Precambrian carbonate sediments and their implication for understanding evolution. In: Bengtson, S. (Ed.) Early Life on Earth, Nobel Symposium 84, Columbia University Press, New York, pp. 245- 258.

Grotzinger, J.P. , Kasting, J.F., 1993. New constraints of Precambrian ocean composition. Journal of Geology $101,235-243$.

Grotzinger, J.P., Rothmans, D.H., 1996. An abiotic model for stromatolite morphogenesis. Nature 383,423-425.

Grotzinger,J.P., Knoll,A.H., 1999. Stromatolites in Precambrian carbonates: evolutionary mileposts or environmental dipsticks? Annual Reviews Earth and Planetary Science 27,313-358. 
Hagadorn, J.W., Bottjer, D.J., 1997. Wrinkle structures: Microbially mediated sedimentary structures common in subtidal siliciclastic settings at the Proterozoic-Phanerozoic transition. Geology 25, 1047-1050.

Hagadorn, J.W., Pflüger, F., Bottjer, D.J., 1999. Unexplored microbial worlds. Palaios 14, 1-2

Hallam, A., 1981. Facies Interpretation and the Stratigraphic Record. W.H. Freeman, Oxford, 291p.

Hallam, A., 1990. Great geological controversies, $2^{\text {nd }}$ ed. Oxford University Press, Oxford, 256p.

Halverson, G.P., Hoffman, P.F., Schrag, D.P., Maloof, A.C., Rice, A.H.N., 2005. Toward a Neoproterozoic composite carbon-isotope record. Geological Society of America Bulletin 117, 1181-1207.

Hambrey, M. J., W. B. Harland, 1981. Earth's Pre-Pleistocene Glacial Record. Cambridge University Press, Cambridge, 1004p.

Hannah, J. L., Bekker, A., Stein, H.J., Markey, R.J., Holland, H.D., 2004. Primitive Os and 2316 Ma age for marine shale: implications for Paleoproterozoic glacial events and the rise of atmospheric oxygen, Earth and Planetary Science Letters 225, 43-52.

Hanson, R.E., Gose, W.A., Crowley, J., Ramezani, S.A., Bowring, D.S., Hall, R.P., Pancake, J.A., Mukwakwami, J., 2004. Paleoproterozoic intraplate magmatism and basin development on the Kaapvaal Craton: Age, paleomagnetism and geochemistry of $\sim 1.93$ to $\sim 1.87$ Ga post-Waterberg dolerites. South African Journal of Geology 107, 233-254.

Hardie, L.A., 2003. Secular variations in Precambrian seawater chemistry and the timing of Precambrian aragonite seas and calcite sea. Geology 31, 785-788.

Hardie, L.A. , Eugster, H.P., 1971. The depositional environment of marine evaporites: A case for shallow, clastic accumulation. Sedimentology 16, 187-220.

Hardie, L.A., Smoot, J.P., Eugster, H.P., 1978. Saline lakes and their deposits: a Sedimentological approach. In: Matter, A., Tucker, M. (Eds.) Modern and Ancient Lake Sediments. International Association of Sedimentologists Special Publication 2, Blackwell, Oxford, pp. 7- 41.

Harris, C.W., Eriksson, K.A., 1990. Allogenic controls on the evolution of storm to tidal shelf sequences in the Early Proterozoic Uncompahgre Group, southwest Colorado, U.S.A. Sedimentology 37, 189-213.

Hayes, J.M., Strauss, H., Kaufman, A.J., 1999. The abundance of ${ }^{13} \mathrm{C}$ in marine organic matter and isotopic fractionation in the global biogeochemical cycle of carbon during the past 800 Ma. Chemical Geology 161, $103-125$. 
Heaman, L.M. , LeCheminant, A.N., 1993. Paragenesis and U-Pb systematics of baddeleyite $\left(\mathrm{ZrO}_{2}\right)$. Chemical Geology 110, 95-126.

Hendry J.P., 1993. Calcite cementation during bacterial manganese, iron and sulphate reduction in Jurassic Shallow marine carbonates. Sedimentology 40, 87-106.

Hoffman, P.F., 1988. United plates of America, the birth of a craton: Early Proterozoic assembly and growth of Laurentia. Annual Reviews of Earth and Planetary Science 16, 543-603.

Hoffman, P.F., Schrag, D.P., 2002. The snowball Earth hypothesis: testing the limits of global change. Terra Nova 14, 129-155.

Hoffman, P.F., Kaufman, A.J., Halverson, G.P., Schrag, D.P., 1998. A Neoproterozoic snowball Earth. Science 281, 1342-1346.

Hoffmann, K.H., Prave, A.R., 1996. A preliminary note on a revised subdivision and regional correlation of the Otavi Group based on glaciogenic diamictites and associated cap dolostones. Geological Survey of Namibia Communications 11, 47-52.

Hoffmann, K.H., Condon, D.J., Bowring, S.A., and Crowley, J.L., 2004. U-Pb zircon date from the Neoproterozoic Ghaub Formation, Namibia: Constraints on Marinoan glaciations. Geology 32, 817-820.

Hofmann, H.J., 1985. The mid-Proterozoic Little Dal macrobiota, Mackenzie Mountains, northwest Canada. Palaeontology 28, 331-354.

Holbrook, J.M., 2001. Origin, genetic interrelationships, and stratigraphy over the continuum of fluvial channel form bounding surfaces: An illustration from middleCretaceous strata, southeastern Colorado. Sedimentary Geology 124, 202-246.

Holbrook, J., Scott, R.W., Oboh-Ikuenobe, F.E., 2006. Base-level buffers and buttresses: a model for upstream versus downstream control on fluvial geometry and architecture within sequences. Journal of Sedimentary Research 76, 162-174.

Holland, H.D., 2002. Volcanic gases, black smokers, and the Great Oxygenation Event. Geochimica et Cosmochimica Acta 66, 3811-3826.

Horodyski, R.J., 1976. Stromatolites of the upper Siyeh Limestone (Middle Proterozoic), Belt Supergroup, Glacier National Park, Montana. Precambrian Research 3, 517-536.

Horodyski, R.J., 1983. Sedimentary geology and stromatolites of the Middle Proterozoic Belt Supergroup, Glacier 
National Park, Montana. Precambrian Research. 20, 391-425.

Hudson, J.D., 1977. Stable isotopes and limestone lithification. Journal of the Geological Society, London 133, 637660.

Hunter, R.E., 1977. Basic types of stratification in small aeolian dunes. Sedimentology 24, 361-387.

Hunter, R.E., 1981. Stratification styles in eolian sandstones: Some Pennsylvanian to Jurassic examples from the western interior U.S.A. In: Etheridge, F.G., Flores, R.M. (Eds.) Recent and Ancient Nonmarine Depositional Environments: Models for Exploration. Special Publications, Society of Economic Paleontologists and Mineralogists 31, Norman, Oklahoma, pp. 315-329.

Iyer, S.S., Babinski, M., Krouse, H.R., Chemale, J.F., 1995. Highly ${ }^{13} \mathrm{C}$ enriched carbonate and organic matter in the Neoproterozoic sediments of the Bambu1 Group, Brazil. Precambrian Research 73, 271-282.

Jackson, M.J., Simpson, E.L., Eriksson, K.A., 1990. Facies and sequence stratigraphic analysis in an intracratonic, thermal-relaxation basin: the Early Proterozoic, Lower Quilalar Formation and Ballara Quartzite, Mount Isa Inlier, Australia. Sedimentology 37, 1053-1078.

Jackson, R.G.II, 1978. Preliminary evaluation of lithofacies models for meandering alluvial streams. In: A.D. Miall (Ed.) Fluvial Sedimentology. Canadian Society of Petroleum Geologists Memoir 5, Calgary, Alberta, pp. 543-576.

Jacobsen, S.B., Kaufman, A.J., 1999. The Sr, C, O isotopic evolution of Neoproterozoic seawater. Chemical Geology 161, 37-57.

James, N.P., Narbonne, G.M., Sherman, A.G., 1998. Molar-tooth carbonates: shallow subtidal facies of the Midto Late Neo-Proterozoic. Journal of Sedimentary Research 68, 716-722.

Kah, L.C., 2000. Preservation of depositional $\delta^{13} \mathrm{C}$ signatures in Proterozoic dolostones: geochemical constraints on seawater chemistry and early diagenesis. In: Grotzinger, J.P., James, N.P. (Eds.) Carbonate Sedimentation and Diagenesis in the Evolving Precambrian World. Special Publication, Society of Economic Paleontologists and Mineralogists 67, Tulsa, Oklahoma, pp. 345-360.

Kah, L.C., Sherman, A.G., Narbonne, G.M., Knoll, A.H., Kaufman, A.J., 1999. $\delta^{13}$ C stratigraphy of the Proterozoic Bylot Supergroup, Baffin Islands, Canada: implications for regional lithostratigraphic correlations. Canadian Journal of Earth Sciences 36, 313-332.

Kakegawa, T., Kawai, H., Ohmoto, H., 1998. Origins of pyrites in the $\sim 2.5$ Ga Mt. McRae Shale, the 
Hamersley District, Western Australia. Geochimica et Cosmochimica Acta 62, 3205-3220.

Karhu, J.A., Holland, H.D., 1996. Carbon isotopes and the rise of atmospheric oxygen. Geology 24, 867-870.

Kasting, J.F., 1993. Earth’s early atmosphere. Science 259, 920-926.

Kasting, J.F., Siefert, J.L., 2002. Life and the evolution of Earth's atmosphere. Science 296, 1066-1068.

Kaufman, A.J., Knoll, A.H., 1995. Neoproterozoic variations in the C-isotopic composition of seawater: stratigraphic and biogeochemical implications. Precambrian Research 73, 27-49.

Kaufman, A.J., Hayes, J.M., Knoll, A.H., Germs, G.J.B., 1991. Isotopic compositions of carbonates and organic carbon from upper Proterozoic successions in Namibia: stratigraphic variation and the effects of diagenesis and metamorphism. Precambrian Research 49, 301-327.

Kaufman, A.J., Knoll, A.H., Narbonne, G.M., 1997. Isotopes, ice ages and terminal Proterozoic earth history. Proceedings of the National Academy of Science USA 94, 6600-6605.

Kempf, O., Kellerhals, P., Lowrie, W., Matter, A., 2000. Paleomagnetic directions in Late Precambrian glaciomarine sediments of the Mirbat Sandstone Formation, Oman. Earth and Planetary Science Letters 175, 181-190.

Kilner, B., Niocaill, C., Brasier, M., 2005. Low latitude glaciations in the Neoproterozoic of Oman. Geology $33(5), 413-416$.

Kirschvink, J.L., 1992. Late Proterozoic low-latitude global glaciation: The Snowball Earth. In: Schopf, J.W., Klein, C., Des Marais, D. (Eds.) The Proterozoic Biosphere: A Multidisciplinary Study. Cambridge University Press, Cambridge, pp. 51-52.

Klein, C., Beukes, N.J., 1989. Geochemistry and sedimentology of a facies transition from limestone to ironformation deposition in the early Proterozoic Transvaal Supergroup, South Africa. Economic Geology 84, 1733-1774.

Klein, C., Beukes, N.J., Schopf, J.W., 1987. Filamentous microfossils in the early Proterozoic Transvaal Supergroup: their morphology, significance, and palaeoenvironmental setting. Precambrian Research 36, $81-94$.

Knoll, A.H., 2003. The geological consequences of evolution. Giobiology 1, 3-14.

Knoll, A. H., Swett, K., 1990. Carbonate deposition during the Late Proterozoic era: An example from Spitsbergen. American Journal of Science 290A, 104-132.

Knoll, A.H., Caroll, S.B., 1999. Early animal evolution: emerging views from comparative biology and geology. 
Science 284, 2129-2137.

Knoll, A.H., Hayes, J.M., Kaufman, A.J., Sweet, K., Lambert, I.B., 1986. Secular variations in carbon isotope ratios from Upper Proterozoic successions of Svalbard and East Greenland. Nature 321, 832-838.

Kocurek, G., Dott, R.H. Jr., 1981. Distinction and uses of stratification type in the interpretation of eolian sand. Journal of Sedimentary Research 51, 579-595.

Kocurek, G., Fielder, G., 1982. Adhesion structures. Journal of Sedimentary Research 51, 1229-1241.

Kocurek, G., Nielson, J., 1986. Conditions favorable for the formation of warm-climate aeolian sand sheets. Sedimentology 33, 795-816.

Kopp, R.E., Kirschvink, J.L., Hilburn, I.A., Nash, C.Z., 2005. The Paleoproterozoic snowball Earth: a climate disaster triggered by the evolution of oxygenic photosynthesis. Proceedings of the National Academy of Science 102 (32), 11131-11136.

Kusky, T. M., Hudleston, P. J., 1999. Growth and demise of an Archaean carbonate platform, Steep Rock Lake, Ontario, Canada. Canadian Journal of Earth Sciences 36, 565-584.

Kuznetsov, V.G., 2003. The 'molar tooth' structure and its relation to bios evolution. Doklady Earth Science 392, 947-950.

Labourdette, R., Jones, R.R., 2007. Characterization of fl uvial architectural elements using a three-dimensional outcrop dataset: Escanilla braided system, South-Central Pyrenees, Spain. Geosphere 3(4), 422-434.

Lambert, M.B., 1998. Stromatolites of the late Archean Back River stratovolcano, Slave structural province, Northwest Territories, Canada. Canadian Journal of Earth Sciences 35, 290-301.

Leeder, M.R.,1982. Sedimentology; Process and Product. George Allen and Unwin, London, 344p.

Lindsay, J.F., Brasier, M.D., 2002. Did global tectonics drive early biosphere evolution? Carbon isotope record from 2.6 to 1.9 Ga carbonates of Western Australian basins. Precambrian Research 114, 1-34.

Lindsay, J.F., Brasier, M.D., 2004. The evolution of the Precambrian atmosphere: carbon isotopic evidence from the Australian continent. In: Eriksson, P.G., Altermann, W., Nelson, D.R., Mueller, W.U., Catuneanu, O. (Eds.) The Precambrian Earth: tempos and events. Elsevier, Amsterdam, pp. 388-403.

Lindsey, K.A., Gaylord, D.R., 1992. Fluvial, coastal, nearshore and shelf deposition in the Upper Proterozoic (?) to Lower Cambrian Addy Quartzite, northeastern Washington. Sedimentary Geology 77, 15-35.

Liu, Y., Gao, L., Liu, Y. 2005. Neoproterozoic molar-tooth structure and constraint of depositional facies and 
environment in the North China Platform in Jiangsu, Anhui and Liaoning, Eastern China. Acta Geol. Sinica $79,533-539$.

Logan, B.W., 1961. Cryptozoan and associated stromatolites from the Recent, Shark Bay. Western Australian Journal of Geology 69,517-533.

Long, D.G.F., 1978. Proterozoic stream deposits: some problems of recognition and interpretation of ancient sandy fluvial systems. In: Miall, A.D. (Ed.) Fluvial Sedimentology. Memoir Canadian Society of Petroleum Geologists 5, Calgary, Alberta, pp. 313-342.

Long, D.G.F., 2004. Precambrian rivers. In: Eriksson, P.G., Altermann, W., Nelson, D.R., Mueller, W.U., Catuneanu, O. (Eds.) The Precambrian Earth: tempos and events. Elsevier, Amsterdam, pp. 660-663.

Loucks, R.G., Longman, M.W., 1982. Lower Cretaceous Ferry Lake anhydrite, Fairway Field, east Texas; product of shallow subtidal deposition. In: Handford, C.R., Loucks, R.G., Davies, G.R. (Eds.) Deposition and Diagenetic Spectra of Evaporites. Society of Economic Paleontologists and Mineralogists, Core Workshop 3, Calgary, Alberta, pp. 130-173.

Lowenstam, H.A., 1981. Minerals formed by organisms. Science 211, 1126-1131.

Lowe, D.R., 1982. Sediment gravity flows: II. Depositional models with special reference to the deposits of high-density turbidity currents. Journal of Sedimentary Petrology 52, 279-297.

Lowe, D.R., 1994. Archean greenstone-related sedimentary rocks. In: Condie, K.C. (Ed.) Archean Crustal Evolution. Elsevier, Amsterdam, pp. 121-169.

Lowe, D.R., 1999. Petrology and sedimentology of cherts and related silicified sedimentary rocks in the Swaziland Supergroup. In: Lowe, D.R., Byerly, G.R. (Eds.) Geological Evolution of the Barberton Greenstone Belt, South Africa. Geological Society of America Special Publication 329, pp. 83-114.

Machado, N., Schrank, A., Noce, C.M., Gauthier, G., 1996. Ages of detrital zircon from Archean-Paleoproterozoic sequences: Implications for greenstone belt setting and evolution of a Transamazonian foreland basin in Quadrilátero Ferrífero, southeast Brazil. Earth and Planetary Science Letters 141, 259-276.

Macintyre, I.G., Prufert-Bebout, L., Reid, R.P., 2000. The role of endolithic cyanobacteria in the formation of lithified laminae in Bahamian stromatolites. Sedimentology 47, 915-921.

Macintyre, I.G., Reid, R.P., Steneck, R.S., 1996. Growth history of stromatolite in a Holocene fringing reef, Stocking Island, Bahamas. Journal of Sedimentary Research 66, 231-242. 
Magaritz, M., Holser, W.T., Kirschvink, J.L., 1986. Carbon-isotope events across the Precambrian/Cambrian boundary on the Siberian Platform. Nature 320, 258-259.

Maliva, R.G., Knoll, A.H., Simonson, B.M., 2005. Secular change in the Precambrian silica cycle: insights from chert petrology. Geological Society of America Bulletin 117, 835-845.

Malone, S.J., Meert, J.G., Banerjee, D.M., Pandit, M.K., Tamrat, E., Kamenov, G.D., Pradhan, V.R., Sohl, L.E., 2008. Paleomagnetism and detrital zircon geochronology of the Upper Vindhyan Sequence, Son Valley and Rajasthan, India: A ca. 1000 Ma age for the Purana Basins? Precambrian Research 164, 137-159.

Marshall, D., Anglin, C.D., 2004. $\mathrm{CO}^{2}$-clathrate destabilization: a new model of formation for molar tooth structures. Precambrian Research 129, 325-341.

Martin, M.W., Grazhdankin, D.V., Bowring, S.A., Evans, D.A.D., Fedonkin, M.A., Kirschvink, J.L., 2000. Age of Neoproterozoic bilaterian body and trace fossils, White Sea, Russia: Implications for metazoan evolution. Science $288,841-845$.

Master, S., 1991. Stratigraphy, tectonic setting, and mineralization of the early Proterozoic Magondi Supergroup, Zimbabwe: a review. Information Circular, Economic Geology Research Unit, University of the Witwatersrand 238, 75p.

Mauclaire, L., Meister, P., Zepp, K., Vasconcelos, C., McKenzie, J.A., 2002. Molecular approach to study microbial communities involved in modern dolomite formation. Geochimica et Cosmochimica Acta 66, A494.

Mazumder, R., Bose, P.K., Sarkar, S., 2000. A commentary on the tectono-sedimentary record of the pre-2.0 Ga continental growth of India vis-à-vis a possible pre-Gondowana Afro-Indian supercontinent. Journal of African Earth Sciences 30, 201-217.

McKenzie, J.A., 1991. The dolomite problem: an outstanding controversy. In: Müller, D.W., McKenzie, J.A., Weissert, H. (Eds.) Controversies in Modern Geology: Evolution of Geological Theories in Sedimentology, Earth History and Tectonics. Academic Press, London, pp. 37-54.

Meinster, B., Tickell, S.J., 1975. Precambrian aeolian deposits in the Waterberg Supergroup. Transactions of the Geological Society of South Africa 78, 191-200.

Melezhik, V.A., Fallick, A.E., Rychanchik, D.V., Kuznetsov, A.B., 2005. Paleoproterozoic evaporites in Fennoscandia: implications for seawater sulfate, the rise of atmospheric oxygen and local amplification of the $\delta 13 \mathrm{C}$ excursion. Terra Nova $17,141-148$. 
Melezhik, V.A., Huhma, H., Condon, D.J., Fallick, A.E., Whitehouse, M.J., 2007. Temporal constrains on the Palaeoproterozoic Lomagundi-Jatuli carbon isotopic event. Geology 35, 655.

Meng, X., Ge, M., 2002. The sedimentary features of Proterozoic microspar (molar-tooth) carbonates in China and their significance. Episodes 25(3), 185-196.

Miall, A.D., 1977. A review of the braided river depositional environment. Earth Science Reviews 13, 1-62.

Miall, A.D., 1978. Lithofacies types and vertical profile models in braided river deposits: a summary. In: Miall, A.D. (Ed.) Fluvial Sedimentology. Canadian Society of Petroleum Geology Memoirs 5, Calgary, Alberta, pp. 597-604.

Miall, A.D., 1984. Principles of Sedimentary Basin Analysis. Springer, New York, 490p.

Miall, A.D., 1985. Architectural-element analysis: a new method of facies analysis applied to fluvial deposits. Earth Science Reviews 22, 261-308.

Miall, A.D, Jones, B., 2003. Fluvial architecture of the Hawkesbury Sandstone (Triassic), near Sydney, Australia. Journal of Sedimentary Research 73, 531-545.

Minter, W.E.L., 1976. Detrital gold, uranium and pyrite concentrations related to sedimentology of the Vaal Reef placer, Witwatersrand, South Africa. Economic Geology 71, 157-176.

Montes, A.S.L., Gravenor, C.P., Montes, M.L., 1985. Glacial sedimentation in the late Precambrian Bebedouro Formation, Bahia, Brazil. Sedimentary Geology 644, 349-358.

Monty, C.L.V., 1976. The origin and development of cryptalgal fabrics. In: Walter, M.R. (Ed.) Stromatolites. Elsevier, New York, pp. 193-249.

Morse, J.W., He, S.L., 1993. Influences of T, $\mathrm{S}$ and $\mathrm{pCO}_{2}$ on the pseudo-homogeneous precipitation of $\mathrm{CaCO}_{3}$ from seawater - Implications for whiting formation. Marine Chemistry 41, 291-297.

Morse, J.W., Gledhill, D.K., Millero, F.J., 2003. $\mathrm{CaCO}_{3}$ precipitation kinetics in waters from the Great Bahama Bank: Implications for the relationship between Bank hydrochemistry and whitings. Geochimica et Cosmochimica Acta 67, 2819-2826.

Moussine-Pouchkine, A., Bertrand-Sarfati, J., 1997. Tectonosedimentary subdivisions in the Neoproterozoic to Early Cambrian cover of the Taoudeni Basin (Algeria-Mauritania-Mali). Journal of African Earth Sciences $24,425-443$.

Mozley, P.S., Burns, S.J., 1993. Oxygen and carbon isotopic composition of marine carbonate concretions: an 
overview. Journal of Sedimentary Petrolology 63, 73-83.

Mueller, W.U., Corcoran, P.L., 1998. Late-orogenic basins in the Archaean Superior Province, Canada: characteristics and inferences. Sedimentary Geology 120, 177-203.

Mueller, W.U., Corcoran, P.L., 2001. Volcano-sedimentary processes operating on a marginal continental arc: the Archean Raquette Lake Formation, Slave Province, Canada. Sedimentary Geology 141-142, 169-204.

Nadson, G.A., 1928. Beitrag zur Kenntnis der Bakteriogenen Kalkablagerungen. Archiv fuer Hydrobiologie 19, $154-164$.

Nelson, D.R., Trendall, A.F., Altermann, W., 1999. Chronological correlations between the Pilbara and Kaapvaal cratons. Precambrian Research 97(3-4), 165-189.

Nemec, W., Steel, R.J., 1988. Fan Deltas: Sedimentology and Tectonic Settings. Blackie, London, 444p.

Nesbitt, H.W., Young, G.M., 1982. Early Proterozoic climates and plate motions inferred from major element chemistry of lutites. Nature 299, 715-717.

Nhleko, N., 2003. The Pongola Supergroup in Swaziland. Unpublished Ph.D. Thesis, Rand Afrikaans University, Johannesburg, South Africa, 299p.

Niedoroda, A.W., Swift, D.J.P., Hopkins, T.S., 1985. The Shoreface. In: Davis, Jr., R.A. (Ed.) Coastal Sedimentary Environments ( $2^{\text {nd }}$ Edition), Springer, Berlin, pp. 533-624.

Noffke, N., Gerdes, G., Klenke, T., Krumbein, W.E., 2001. Microbially induced sedimentary structures - A new category within the classification of primary sedimentary structures. Journal of Sedimentary Research 71, 649-656.

Noffke, N., Knoll, A.H., Grotzinger, J.P., 2002. Ecology and taphonomy of microbial mats in late Neoproterozoic siliciclastics: a case study from the Nama Group, Namibia. Palaios 17, 1-12.

Noffke, N., Gerdes, G., Klenke, T., 2003. Benthic cyanobacteria and their influence on the sedimentary dynamics of peritidal depositional systems (siliciclastic, evaporitic salty, and evaporitic carbonatic). Earth Science Reviews 62, 163-176.

Noffke, N., Eriksson, K.A., Hazen, R.M., Simpson, E.L., 2006. A new window into Early Archaean life: Microbial mat in Earth's oldest siliciclastic tidal deposits (3.2 Ga Moodies Group, South Africa). Geology 34, 253256.

O’Conner, M.P., 1972. Classification and environmental interpretation of the cryptalgal organosedimentary 
'molartooth' structure of the Precambrian Belt-Purcell Supergroup. Journal of Geology 80, 592-610.

Ohmoto, H., 2004. The Archaean atmosphere, hydrosphere and biosphere. In: Eriksson, P.G., Altermann, W., Nelson, D.R., Mueller, W.U., Catuneanu, O. (Eds.) The Precambrian Earth: tempos and events. Elsevier, Amsterdam, pp. 361-388.

Olsen, P.E., Remington, C.L., Corliss, B., Thompson, K.S., 1978. Change in late Triassic lacustrine communities. Science 201, 729-733.

Ordonez, S., Calvo, J.P., Garcia del Cura, M.A., Alonso-Zarza, A.M., Hoyos, M., 1991. Sedimentology of sodium sulphate deposits and special clays from the Tertiary Madrid Basin (Spain). In: Anadon, P., Cabrera, L., Kelts, K. (Eds.) Lacustrine Facies Analysis. International Association of Sedimentologists, Special Publication 13, pp. 39-55.

Pareek, H. S., 1984. Pre-Quaternary geology and mineral resources of northwestern Rajasthan. Memoir Geological Survey of India 115, 1-95.

Parizot, M., Eriksson, P.G., Aifa, T., Sarkar, S., Banerjee, S., Catuneanu, O., Altermann, W., Bumby, A.J., Bordy, E.M., van Rooy, J.L., Boshoff, A.J., 2005. Suspected microbial mat-related crack-like sedimentary structures in the Palaeoproterozoic Magaliesberg Formation sandstones, South Africa. Precambrian Research 138, 274-296.

Patterson, J.G., Heaman, L.M., 1991. New geochronologic limits on the depositional age of the Hurwitz Group, Trans-Hudson hinterland, Canada. Geology 19, 1137-1140.

Pavlov, A.A., Kasting, J.F., Eigenbrode, J.L., Freeman, K.H., 2001. Organic haze in Earth's early atmosphere: source of low- ${ }^{13}$ C late Archean kerogens? Geology 29, 1003-1006.

Pettijohn, F.J., 1970. The Canadian Shield: a status report, 1970. In: Baer, A.J. (Ed.) Symposium on Basins and Geosynclines of the Canadian Shield. Report, Geological Survey of Canada 70-40, 239-265.

Pettijohn, F.J., 1972. The Archean of the Canadian Shield: a resume. Geological Society of America Memoir 135, 131-149.

Pettijohn, F.J., Potter, P.E., 1964. Atlas and Glossary of Sedimentary Structures. Springer, New York, 370p

Pettijohn, F.J., Potter, P.E., Siever, R., 1972. Sand and Sandstone. Springer, New York, 618p.

Pflüger, F., 1999. Matground structures and redox facies. Palaios 14, 25-39.

Pflüger, F., Seilacher, A., 1991. Flash flood conglomerates. In: Einsele, G., Richen, W., Seilacher, A. (Eds.) Cycles 
and Events in Stratigraphy. Springer, Berlin, pp. 383-391.

Pflüger, F., Gresse, P.G., 1996. Microbial sandchips - a non-actualistic sedimentary structure. Sedimentary Geology $102,263-274$.

Pollock, M.D., Kah, L.C., Bartley, J.K., 2006. Morphology of molar-tooth structures in Precambrian carbonates: influence of substrate rheology and implications for genesis. Journal of Sedimentary Research 76, 310-323.

Pope, M.C., Bartley, J.K., Knoll, A.H., Petrov, P.Y., 2003. Molar tooth structures in calcareous nodules, early Neoproterozoic Burovaya Formation, Turukhansk region, Siberia. Sedimentary Geology 158, 235-248.

Pratt, B.R., 1998a. Molar-tooth structure in Proterozoic carbonate rocks: Origin from synsedimentary earthquakes, and implications for the nature and evolution of basins and marine sediment. Geological Society of America Bulletin 110, 1028-1045.

Pratt, B.R., 1998b. Syneresis cracks: subaqueous shrinkage in argillaceous sediments caused by earthquake-induced dewatering. Sedimentary Geology 117, 1-10.

Pratt, B.R., 1999. Gas bubble and expansion crack origin of molar-tooth calcite structures in the middle Proterozoic Belt Supergroup, western Montana - Discussion. Journal of Sedimentary Research 69, 1136-1140.

Pratt, B.R., 2001. Oceanography, bathymetry and syndepositional tectonics of a Precambrian intracratonic basin: integrating sediments, storms, earthquakes and tsunamis in the Belt Supergroup (Helena Formation, ca. 1.45 Ga), western North America. Sedimentary Geology 141-142, 371-394.

Pratt, B.R., James, N.P., 1986. The St. George Group (Lower Ordovician) of western Newfoundland: Tidal flat island model for carbonate sedimentation in shallow epeiric seas. Sedimentology 33, 313-343.

Pratt, B.R., Holmden, C. (Eds.), 2008. Dynamics of epeiric seas. Special Publication, Geological Association of Canada 48, St. John's, Newfoundland, 406p.

Rainbird, R.H., 1992. Anatomy of a large-scale braid-plain quartzarenite from the Neoproterozoic Shaler Group, Victoria Island, Northwest Territories, Canada. Canadian Journal of Earth Sciences 29, 2537-2550.

Ramaekers, P., Catuneanu, O., 2004. Development and sequences of the Athabasca basin, early Proterozoic, Saskatchewan and Alberta, Canada. In: Eriksson, P.G., Altermann, W., Nelson, D.R., Mueller, W.U., Catuneanu, O. (Eds.) The Precambrian Earth: tempos and events. Elsevier, Amsterdam, pp. 705-723.

Ray, J.S., 2006. Age of the Vindhyan Supergroup: a review of the recent findings. Journal of Earth System Sciences $115,149-160$. 
Reading, H.G. (Ed.), 1978. Sedimentary Environments and Facies. Blackwell, Oxford, 557p.

Reeves, C.C., 1968. Introduction to Paleolimnology. Developments in Sedimentology 11, Elsevier, Amsterdam, $228 \mathrm{p}$.

Reid, R.P., Macintyre, I.G., Steneck, R.S., Browne, K.M., Miller, T.E., 1995. Stromatolites in the Exuma Cays, Bahamas: Uncommonly common. Facies 33, 1-18.

Reid, R.P., Visscher., P.T., Decho, A.W., Stolz, J.F., Bebout, B.M., Dupraz, C., Macintyre, I.G., Paerl, H.W., Pinckney, J.L., Prufert-Bebout, L., Steppe, T.F., Des Marais, D.J., 2000. The role of microbes in accretion, lamination and early lithification of modern marine stromatolites. Nature 406, 989-992.

Ridgwell, A., Zeebe, R.E., 2005. The role of the global carbonate cycle in the regulation and evolution of the Earth system. Earth and Planetary Science Letters 234, 299-315.

Riding, R., 1982. Cyanophyte calcification and changes in ocean chemistry. Nature 299, 814-815.

Riding, R., 2006. Microbial carbonate abundance compared with fluctuations in metazoan diversity over geological Time. Sedimentary Geology 185, 229-238.

Riding, R., Liang, L., 2005. Seawater chemistry control of marine limestone accumulation over the past 550 million years. Revista Española de Micropaleontología 37, 1-11.

Robb, L.J., Meyer, F.M., 1995. The Witwatersrand Basin, South Africa: geological framework and mineralization processes. Economic Geology Research Unit, Information Circular 293, University of Witwatersrand, Johannesburg, South Africa, 37p.

Robbins, L.L., Blackwelder, P.L., 1992. Biochemical and ultrastructural evidence for the origin of whitings: a biologically induced calcium carbonate precipitation mechanism. Geology 20, 464-468.

Robbins, L.L., Yates, K.K., Shinn, G., Blackwelder, P., 1996. Whitings on the Great Bahama Bank: A microscopic solution to a macroscopic mystery. Bahamas Journal of Science 4, 2-7.

Roberts, J.A., Bennett, P.C., González, L.A., Macpherson, G.L., Milliken, K.L., 2004. Microbial precipitation of dolomite in methanogenic groundwater. Geology 32, 277-280.

Ronov, A.B., 1964, Common tendencies in the chemical evolutions of the Earth's crust, ocean and atmosphere. Geochemistry International 4, 713-737.

Rothman, D., Hayes, J.M., Summons, R.E., 2003. Dynamics of the Neoproterozoic carbon cycle. Proceedings of the National Academy of Sciences 10, 8124-8129. 
Roy, A.B., Jakhar, S.R., 2002. Geology of Rajasthan (Northwest India), Precambrian to Recent. Scientific Publishers, India, 421p.

Samanta, P., 2008. Proterozoic siliciclastic sedimentation and sequence building - possible role of microbial mat: Sonia Sandstone, Rajasthan, India. Unpublished Ph.D. thesis, Jadavpur University, India, 206p.

Samanta, P., Sarkar, S., Mukhopadhyay, S., Bose, P.K., 2007. Channel pattern, sequence-building and their implications in the basal fluvial, Neoproterozoic Sonia Sandstone, India. Abstract volume, International Seminar on "Precambrian Sedimentation and Tectonics", IIT Bombay, Mumbai, India. p.35

Samanta, P., Mukhopadhyay, S., Sarkar, S., 2008. Stratigraphic Architecture of the lower fluvial interval, Sonia Sandstone, Jodhpur. Abstract, International Seminar, ISI, Kolkata, India. p. 95.

Santos, R.V., de Alvarenga, C.J.S., Dardenne, M.A., Sial, A.N., Ferreira, V.P., 2000. Carbon and oxygen isotope profiles across Meso-Neoproterozoic limestones from central Brazil: Bambuı and Paranoa Groups. Precambrian Research 104, 107-122.

Sarkar, S., Chakraborty, S., Banerjee, S., P.K. Bose, 2002a. Facies sequence and cryptic imprint of sag tectonics in late Proterozoic Sirbu Shale, central India. In: Altermann, W., Corcoran, P. (Eds.) Precambrian Sedimentary Environments: A Modern Approach to Ancient Depositional Systems. Special Publications, International Association of Sedimentologists 33, Blackwell, Oxford, pp. 369-382.

Sarkar, S., Banerjee, S., Chakraborty, S., Bose, P.K., 2002b. Shelf storm flow dynamics: insight from the Mesoproterozoic Rampur Shale, central India. Sedimentary Geology 147, 89-104.

Sarkar, S., Eriksson, P.G., Chakraborty, S., 2004. Epeiric sea formation on Neoproterozoic supercontinent break-up: a distinctive signature in coastal storm bed amalgamation. Gondwana Research 7, 313-322.

Sarkar, S., Banerjee, S., Eriksson, P.G., Catuneanu, O., 2005. Microbial mat control on siliciclastic Precambrian sequence stratigraphic architecture: Examples from India. Sedimentary Geology 176, 195-209.

Sarkar, S., Banerjee, S., Samanta, P., Jeevankumar, S., 2006. Micrbial mat-induced sedimentary structures in siliciclastic sediments: examples from the 1.6 Ga Chorhat Sandstone, Vindhyan Supergroup, M.P., India. Journal of Earth System Science 115(1), 49-60.

Sarkar, S., Bose, P.K., Samanta, P., Sengupta, P., Eriksson, P.G., 2008. Microbial mat mediated structures in the Ediacaran Sonia Sandstone, Rajasthan, India, and their implications for Proterozoic sedimentation. Precambrian Research 162, 248-263. 
Schidlowski, M., Todt, W., 1998. The Proterozoic Lomagundi carbonate province as paragon of a 13C enriched carbonate facies: Geology, radiometric age and geochemical significance. ICOG-9, Chinese Science Bulletin 43, 114.

Schidlowski, M., Eichmann, R., Junge, C.E., 1975. Precambrian sedimentary carbonates: carbon and oxygen isotope geochemistry and implications for the terrestrial oxygen budget. Precambrian Research 2, 1-69.

Schidlowski, M., Eichmann, R., Junge, C.E., 1976. Carbon isotope geochemistry of the Precambrian Lomagundi carbonate province. Geochimica et Cosmochimica Acta 40, 449-455.

Schieber, J., 1989. Facies and origin of shales from the mid-Proterozoic Newland Formation, Belt Basin, Montana, U.S.A. Sedimentology 36, 203-219.

Schieber, J., 1998. Possible indicators of microbial mat deposits in shales and sandstones: examples from the MidProterozoic Belt Supergroup, Montana, U.S.A. Sedimentary Geology 120, 105-124.

Schieber, J., 1999. Microbial mats in terrigenous clastics: The challenge of identification in the rock record. Palaios $14,3-12$.

Schieber, J., 2004. Microbial mats in the siliciclastic rock record: a summary of the diagnostic features. In: Eriksson, P.G., Altermann, W., Nelson, D.R., Mueller, W.U., Catuneanu. O. (Eds.) The Precambrian Earth: Tempos and Events. Elsevier, Amsterdam, pp. 663-673.

Schieber, J., 2007. Microbial mats on muddy substrates - examples of possible sedimentary features and underlying Processes. In: Schieber, J., Bose, P.K., Eriksson, P.G., Banerjee, S., Sarkar, S., Altermann, W., Catuneanu, O. (Eds.) Atlas of Microbial Mat features preserved within the Siliciclastic Rock Record . Atlases in Geoscience 2. Elsevier, Amsterdam, pp. 117-133.

Schieber, J., Bose, P.K., Eriksson, P.G., Banerjee, S., Sarkar, S., Altermann, W., Catuneanu, O. (Eds.), 2007. Atlas of Microbial Mat features preserved within the Siliciclastic Rock Record. Atlases in Geoscience 2. Elsevier, Amsterdam, 311p.

Schmidt, P.W., Williams, G.E., 1999. Paleomagnetism of the Paleoproterozoic hematitic breccia and paleosol at Ville-Marie, Quebec: further evidence for the low paleolatitude of Huronian glaciation. Earth and Planetary Science Letters 172, 273-285.

Schopf, J.W., 1999. Cradle of Life: The discovery of Earth's earliest fossils. Princeton University Press, New Jersey, $367 \mathrm{p}$. 
Schreiber, U.M., Eriksson, P.G., Snyman, C.P., 1991. A provenance study of the sandstones of the Pretoria Group, Transvaal Sequence (South Africa): petrography, geochemistry, and palaeocurrent indicators. South African Journal of Geology 94(4), 288-298.

Schreiber, U.M., Eriksson, P.G., Snyman, C.P., 1992. Mudrock geochemistry of the Proterozoic Pretoria Group, Transvaal Sequence (South Africa): geological implications. Journal of African Earth Sciences 14(3), 393409.

Schumm, S.A., 1968. Speculations concerning palaeohydrologic controls of terrestrial sedimentation. Geological Society of America Bulletin 79, 1573-1588.

Sheldon, N.D., 2006. Precambrian paleosols and atmospheric $\mathrm{CO}_{2}$ levels. Precambrian Research 147, $148-155$.

Shen Y., Buick R., 2004. The antiquity of microbial sulphate reduction. Earth Science Reviews 64, $243-272$.

Shields, G.A., 2002. Molar tooth microspar: a chemical explanation for its disappearance $\sim 750$ Ma. Terra Nova 14, 108-113.

Siedlecka, A., Pickering, K.T., Edwards, M.B., 1989. Upper Proterozoic passive margin deltaic complex, Finnmark, N Norway. In: Whateley, M.K.G., Pickering, K.T. (Eds.) Deltas: Sites and Traps for Fossil Fuels. Special Publication, Geological Society, London 41, pp. 205-219.

Simonson, B.M., Schubel, K.A., Hassler, S.W., 1993. Carbonate sedimentology of the early Precambrian Hamersley Group of Western Australia. Precambrian Research 60, 287-335.

Simpson, E.L., Eriksson, K.A., Eriksson, P.G., Bumby, A.J., 2002. Eolian dune degradation and generation of massive sandstones in the Paleoproterozoic Makgabeng Formation, Waterberg Group, South Africa. Journal of Sedimentary Research 72, 40-45.

Simpson, E.L., Alkmim, F.F., Bose, P.K., Bumby, A.J., Eriksson, K.A., Eriksson, P.G., Martins-Neto, M.A., Middleton, L.T., Rainbird, R.H., 2004a. Sedimentary dynamics of Precambrian aeolianites. In: Eriksson, P.G., Altermann, W., Nelson, D.R., Mueller, W.U., Catuneanu, O. (Eds.) The Precambrian Earth: tempos and events. Elsevier, Amsterdam, pp. 642-657.

Simpson, E.L., Eriksson, K.A., Kuklis, C.A., Eriksson, P.G., Bumby, A.J., van Jaarsveld, C.F., 2004b. Saline pan deposits from the 1.8 Ga Makgabeng Formation, Waterberg Group, South Africa. Sedimentary Geology $163,279-292$.

Slaughter, M., Hill, R.J.,1991. The influence of organic matter im organogenic dolomitization. Journal 
of Sedimentary Petrology 61(2), 296-303.

Smith, A.G., 1968. The origin and deformation of some molar-tooth structures in the Precambrian Belt-Purcell Supergroup. Journal of Geology 76, 426-443.

Smith, A.G., 2009. Neoproterozoic time scales and stratigraphy. In: Craig, J., Thurow, J., Thusu, B., Whitham, A., Abutarruma, Y. (Eds.) Global Neoproterozoic petroleum systems: the emerging potential in North Africa. Special Publications, Geological Society, London 326, pp. 27-54.

Smith, S.V., Winston, D., 1997. Formation of cracks in subaqueous fluid mud by solitary waves, central Louisiana Gulf of Mexico coast. Abstract, Geological Society of America Abstracts with Programs 29(6), p. A-440.

Soegaard, K., Eriksson, K.A., 1985. Evidence of tide, storm, and wave interaction on a Precambrian siliciclastic shelf: the 1.700 M.Y. Ortega Group, New Mexico. Journal of Sedimentary Petrology 55, 672-684.

Sohl, L.E., Christie-Blick, N., Kent, D.V., 1999. Paleomagnetic polarity reversals in Marinoan (ca. 600 Ma) glacial deposits of Australia: Implications for the duration of low-latitude glaciaation in neoproterozoic time. Geological Society of America Bulletin 111, 1120-1139.

Soni, M.K., Chakraborty, S., Jain, V.K., 1987. Vindhyan Supergroup - A review. Geological Society of India Memoir 6, 87-136.

Sreenivasa Rao, T., 1987. The Pakhal basin - A perspective. Geological Society of India Memoir 6, 161-187.

Stanistreet, I.G., McCarthy, T.S., 1991. Changing tectono-sedimentary scenarios relevant to the development of the Late Archaean Witwatersrand Basin. Journal of African Earth Sciences 13, 65-82.

Stow, D.A.V., 1986. Deep clastic seas. In: Reading, H.G. (Ed.) Sedimentary Environments and Facies, $2^{\text {nd }}$ edition. Blackwell, Oxford, pp. 399-444.

Strong N., Sheets, B., Hickson, T., Paola, C., 2005. A mass-balance framework for quantifying downstream changes in fluvial architecture. In: Blum, M.D., Marriott, S.B., Leclair, S.F. (Eds.) Fluvial Sedimentology VII. Special Publication, International Association of Sedimentologists 35, Blackwell, Oxford, pp. 243-253.

Sumner, D.Y., 1997. Carbonate precipitation and oxygen stratification in late Archean seawater as deduced from facies and stratigraphy of the Gamohaan and Frisco formations, Transvaal Supergroup, South Africa. American Journal of Science 297, 455-487.

Sumner, D.Y., Grotinger, J.P., 1996. Were kinetics of Archean calcium carbonate precipitation related to oxygen concentration? Geology 24, 119-122. 
Sumner, D.Y., Grotzinger, J.P., 2000. Late Archaean aragonite precipitation: petrography, facies associations, and environmental significance. In: Grotzinger, J.P., James, N.P. (Eds.) Carbonate sedimentation and diagenesis in the evolving Precambrian world. Special Publication, Society of Economic Paleontologists and Mineralogists 67, pp. 123-144.

Sweet, I.P., 1988. Early Proterozoic stream deposits: braided or meandering - evidence from central Australia. Sedimentary Geology 58, 277-293.

Swett, K., Klein, G.deV., Smit, D.E., 1971. A Cambrian tidal sand body — the Eriboll Sandstone of Northwest Scotland: an ancient-recent analog. Journal of Geology 79, 400-415.

Tirsgaard, H., Sønderholm, M., 1997. Lithostratigraphy, sedimentary evolution and sequence stratigraphy of the Upper Proterozoic Lyell Land Group (Eleonore Bay Supergroup) of East and Northeast Greenland. Geological Survey of Greenland Bulletin 178, 60p.

Tirsgaard, H., Øxnevad, I.E.I., 1998. Preservation of pre-vegetational fluvio-aeolian deposits in a humid climatic setting: an example from the Middle Proterozoic Eriksfjord Formation, southwest Greenland. Sedimentary Geology 120, 295-317.

Trendall, A.F., 2002. The significance of iron-formation in the Precambrian stratigraphic record. In: Altermann, W., Corcoran, P.L. (Eds.) Precambrian Sedimentary Environments: a Modern Approach to Depositional Systems. Special Publication of the International Association of Sedimentologists 44, Blackwell, Oxford, pp. 33-66.

Trendall, A.F., Blockley, J.G., 2004. Precambrian iron-formation. In: Eriksson, P.G., Altermann, W., Nelson, D.R., Mueller, W.U., Catuneanu, O. (Eds.) The Precambrian Earth: tempos and events. Elsevier, Amsterdam, pp. 403-421.

Tucker, M.E., 1992. The Precambrian-Cambrian boundary: Seawater chemistry, ocean circulation, and nutrient supply in metazoan evolution, extinction, and biomineralization. Journal of the Geological Society, London $149,655-668$.

Tucker, M.E., Wright, V.P., Dickson, J.A.D., 1990. Carbonate sedimentology. Blackwell, Oxford, 482p.

Ueno, Y., Ono, S., Rumble, D., Maruyama, S., 2008. Quadruple sulfur isotope analysis of ca. 3.5 Ga Dresser Formation: new evidence for microbial sulfate reduction in the early Archean. Geochimica et Cosmochimica Acta 72, 5675-5691. 
Van der Neut, M., Eriksson, P.G., 1999. Palaeohydrological parameters of a Proterozoic braided fluvial system (Wilgerivier Formation, Waterberg Group, South Africa) compared with a Phanerozoic example. Special Publication, International Association of Sedimentologists 28, Blackwell, Oxford, pp. 381-392.

Van der Neut, M., Eriksson, P.G., Callaghan, C.C., 1991. Distal alluvial fan sediments in early Proterozoic red beds of the Wilgeriver Formation, Waterberg Group, South Africa. Journal of African Earth Sciences 12, 537547.

Van Kranendonk, M.J., 2006. Volcanic degassing, hydrothermal circulation and the flourishing of early life on Earth: new evidence from the Warrawoona Group, Pilbara Craton, Western Australia. Earth Science Reviews 74, 197-240.

Van Kranendonk, M.J., Webb, G.E., Kamber, B.S., 2003. Geological and trace element evidence for a marine sedimentary environment of deposition and biogenicity of $3.45 \mathrm{Ga}$ stromatolitic carbonates in the Pilbara Craton, and support for a reducing Archean ocean. Geobiology 1(2), 91-108.

Van Kranendonk, M.J., Hickman, A.H., Smithies, R.H., Williams, I.R., Bagas, L., Farrell,T.R., 2006. Revised lithostratigraphy of Archean supracrustal and intrusive rocks in the Northern Pilbara Craton, Western Australia. Western Australia Geological Survey Record 2006/15, 57p.

Van Kranendonk, M.J., Philippot, P., Lepot, K., Bodorkos, S., Pirajno, F., 2008. Geological setting of Earth’s oldest fossils in the c. 3.5 Ga Dresser Formation, Pilbara Craton, Western Australia. Precambrian Research 167, 93-124.

Van Lith, Y., Warthmann, R., Vasconcelos, C., McKenzie, J.A., 2003. Sulphate reducing bacteria induce lowtemperature Ca-dolomite and high Mg-calcite formation. Geobiology 1, 71-79.

Vasconcelos C., McKenzie, J.A., 1997. Microbial mediation of modern dolomite precipitation and diagenesis under anoxic conditions (Lagoa Vermelha, Rio de Janeiro, Brazil). Journal of Sedimentary Research 67, 378-390.

Vasconcelos C., McKenzie, J.A., 2000. Sulphate reducers_dominant players in a low-oxygen world? Science 290, 1711.

Vasconcelos, C., Mckenzie, J.A., Bernasconi, S., Grujic, D., Tien, A.J., 1995. Microbial mediation as a possible mechanism for natural dolomite formation at low temperature. Nature 377, 220-222.

Veizer, J., Compston, W., 1976. ${ }^{87} \mathrm{Sr} /{ }^{86} \mathrm{Sr}$ in Precambrian carbonates as an index of crustal evolution. Geochimica et Cosmochimca Acta 40, 905-914. 
Veizer, J., Jansen, S.L., 1985. Basement and sedimentary recycling-2: time dimensions to global tectonics. Journal of Geology 93, 625-643.

Veizer, J., Holser, W.T., Wilgus, C.K., 1980. Correlation of ${ }^{13} \mathrm{C} /{ }^{12} \mathrm{C}$ and ${ }^{34} \mathrm{~S} /{ }^{32} \mathrm{~S}$ secular variations. Geochimica et Cosmochimica Acta 44, 579-587.

Veizer, J., Compston, W., Clauer, N., Schidlowski, M., $1983 .{ }^{87} \mathrm{Sr} /{ }^{86} \mathrm{Sr}$ in late Proterozoic carbonates: Evidence for a "mantle" event at 900 Ma ago. Geochimica et Cosmochimica Acta 47, 295-302.

Veizer, J., Clayton, R.N., Hinton, R.W., 1992. Geochemistry of Precambrian carbonates: Early Palaeoproterozoic $(2.25 \pm 0.25 \mathrm{Ga})$ seawater. Geochimica et Cosmochimica Acta $56,875-885$.

Visscher, P.T., Reid, R.P., Bebout, B.M., Hoeft, S.E, Macintyre, I.G., Thompson, J.A.Jr., 1998. Formation of lithified micritic laminae in modern marine stromatolites (Bahamas): the role of sulfur cycling. American Mineralogist 83, 1482- 1493.

Visscher, P.T., Reid, R.P., Bebout, B.M., 2000. Microscale observations of sulphate reduction: correlation of microbial activity with lithified micritic laminae in modern marine stromatolites. Geology 28, 919-922.

Voegelin, A.R., Nägler, T.F., Beukes, N.J. Lacassie, J.P., 2010. Molybdenum isotopes in late Archean carbonate rocks: Implications for early Earth oxygenation. Precambrian Research 182, 70-82.

Walker, R.G., 1984, Shelf and shallow marine sands. In: Walker, R.G. (Ed.) Facies Models. Geological Society of Canada Reprint Series 1, Toronto, pp. 141-170.

Walker, R.G., Plint, A.G., 1992. Wave- and storm-dominated shallow marine systems. In: Walker, R.G., James, N.P. (Eds.) Facies Models, Response to Sea Level Change. Geological Association of Canada, Toronto, pp. 219-238.

Walraven, F., Hattingh, E., 1993. Geochronology of the Nebo granite, Bushveld Complex. South African Journal of Geology 96, 31-41.

Walter, L.M., Bischof, S.A., Patterson, W.P., Lyons, T.W., 1993. Dissolution and recrystallization in modern shelf carbonates — Evidence from pore-water and solid-phase chemistry. Royal Society, London, Philospohical Transaction A344, 27-36.

Walter, M.R., Heys, G.R., 1985. Links between the rise of the Metazoa and the decline of stromatolites. Precambrian Research 29, 149-174.

Walter, M.R., Veevers, J.J., Calver, C.R., Gorjan, P., Hill, A.C., 2000. Dating the 840-544 Ma Neoproterozoic 
interval by isotopes of strontium, carbon, and sulfer in seawater, and some interpretative models. Precambrian Research 100, 371-433.

Warthmann, R., van Lith, Y., Vasconcelos, C., McKenzie, J.A., Karpoff, A.M., 2000. Bacterially induced dolomite precipitation in anoxic culture experiments. Geology 28, 1091-1094.

Whipple, K.X, Parker, G., Paola, C., Mohrig, D., 1998. Channel dynamics, sediment transport, and the slope of the alluvial fans: experimental study. Journal of Geology 106, 677-693.

Wilde, S.A., Valley, J.W., Peck, W.H., Graham, C.M., 2001. Evidence from detrital zircons for the existence of continental crust and oceans on the Earth 4.4 Gyr ago. Nature 409, 175-178.

Williams, G.E., Schmidt, P.W., 1997. Paleomagnetism of the Paleoproterozoic Gowganda and Lorrain formations, Ontario; low paleolatitude for Huronian glaciation. Earth and Planetary Science Letters 153, 157-169.

Williams, H., Hoffman, P.F., Lewry, J.F., Monger, J.W.H., Rivers, T., 1991. Anatomy of North America: thematic portrayals of the continent. Tectonophysics 187, 117-134.

Willis, B.J., 1997. Architecture of fluvial-dominated valley-fill deposits in the Cretaceous Fall River Formation. Sedimentology 44, 735-57.

Winhusen, E. R., 2001. Precambrian seawater temperature analysis using oxygen isotopes from Hamersley Carbonates, Western Australia. Unpublished M. Sc thesis, University of Cincinnati.

Winston, D., 1986. Sedimentology of the Ravalli Group, Middle Belt Carbonate and Missoula Group, Middle Proterozoic Belt Supergroup, Montana, Idaho, and Washington. Montana Bureau of Mines and Geology, Special Publication 94, 85-124.

Wright, D.T., 1997. Organogenic origin for widespread dolomite in the Cambrian Eilean Dubh Formation, northwestern Scotland. Journal of Sedimentary Research 67, 54-64.

Wright D.T., 1999. The role of sulphate-reducing bacteria and cyanobacteria in dolomite formation in distal ephemeral lakes of the Coorong region, South Australia. Sedimentary Geology 126, 147-157.

Wright, D.T., 2000. Benthic microbial communities and dolomite formation in marine and lacustrine environments - a new dolomite model. In: Glenn, C.R., Prévôt-Lucas, L., Lucas, J. (Eds.) Marine Authigenesis: From Global to Microbial. Special Publication, Society for Sedimentary Geology 66, Tulsa, Oklahoma, pp. 7-20.

Wright, D.T., Altermann, W., 2000. Microfacies development in late Archaean stromatolites and ooids of the Ghaap 
Group, Republic of South Africa. In: Insalaco, E., Skelton, P.W., Palmer, T.J., (Eds.) Carbonate Platform Systems: Components and Interactions. Special Publication, Geological Society, London 178, pp. 51-70.

Wright, D.T., Wacey, D., 2004. Sedimentary dolomite - a reality check. In: Braithwaite, C.J.R., Rizzi, G., Darke, G. (Eds.) The Geometry and Petrogenesis of Dolomite Hydrocarbon Reservoirs. Special Publication, Geological Society 235, London, pp. 65-74.

Wright, D.T., Oren, A., 2005. Non-photosynthetic bacteria in and the formation of carbonates and evaporates through time. Geomicrobiology Journal 22, 27-53.

Wright, D.T. and Wacey, D., 2005. Dolomite precipitation in experiments using sulfate-reducing bacteria population in simulated lake and pore waters from distal ephemeral lakes Coorong region, South Australia. Sedimentology 52, 987-1008.

Xianghua, M., Ming, G., 2002. The sedimentary features of Proterozoic microspar (Molar-tooth) carbonates in China and their significance. Episodes 25, 185-195.

Xiao, S., Knoll, A.H., 1999. Fossil preservation in the Neoproterozoic Doushantuo phosphorite Lagerstatte, South China. Lethaia 32, 219-240.

Young, G.M., 1991. The geologic record of glaciation: relevance to the climatic history of the Earth. Geoscience Canada 18, 100-108.

Young, G.M., 2004. Earth's two great Precambrian glaciations: aftermath of the "Snowball Earth" hypothesis. In: Eriksson, P.G., Altermann, W., Nelson, D.R., Mueller, W.U., Catuneanu, O. (Eds.) The Precambrian Earth: tempos and events. Elsevier, Amsterdam, pp. 440-448.

Young, G.M., Long, D.G.F., 1977. Carbonate sedimentation in a late Precambrian shelf sea, Victoria Island, Canadian Arctic Archipelago. Journal of Sedimentary Petrology, 47, 943-955.

Young, G.M., Von Brunn, V., Gold, D.J.C., Minter, W.E.L., 1998. Earth’s oldest reporetd glaciation:

Physical and chemical evidence from the Archaean Mozaan Group ( 2.9Ga) of South Africa. Journal of Geology 106, 523-538.

Yu, X., Ma, X., Quing, H., 2002. Sedimentology and reservoir characteristics of a Middle Jurassic fluvial system, Datong Basin, northern China. Bulletin of Canadian Petroleum Geology 50(1), 105-117. 


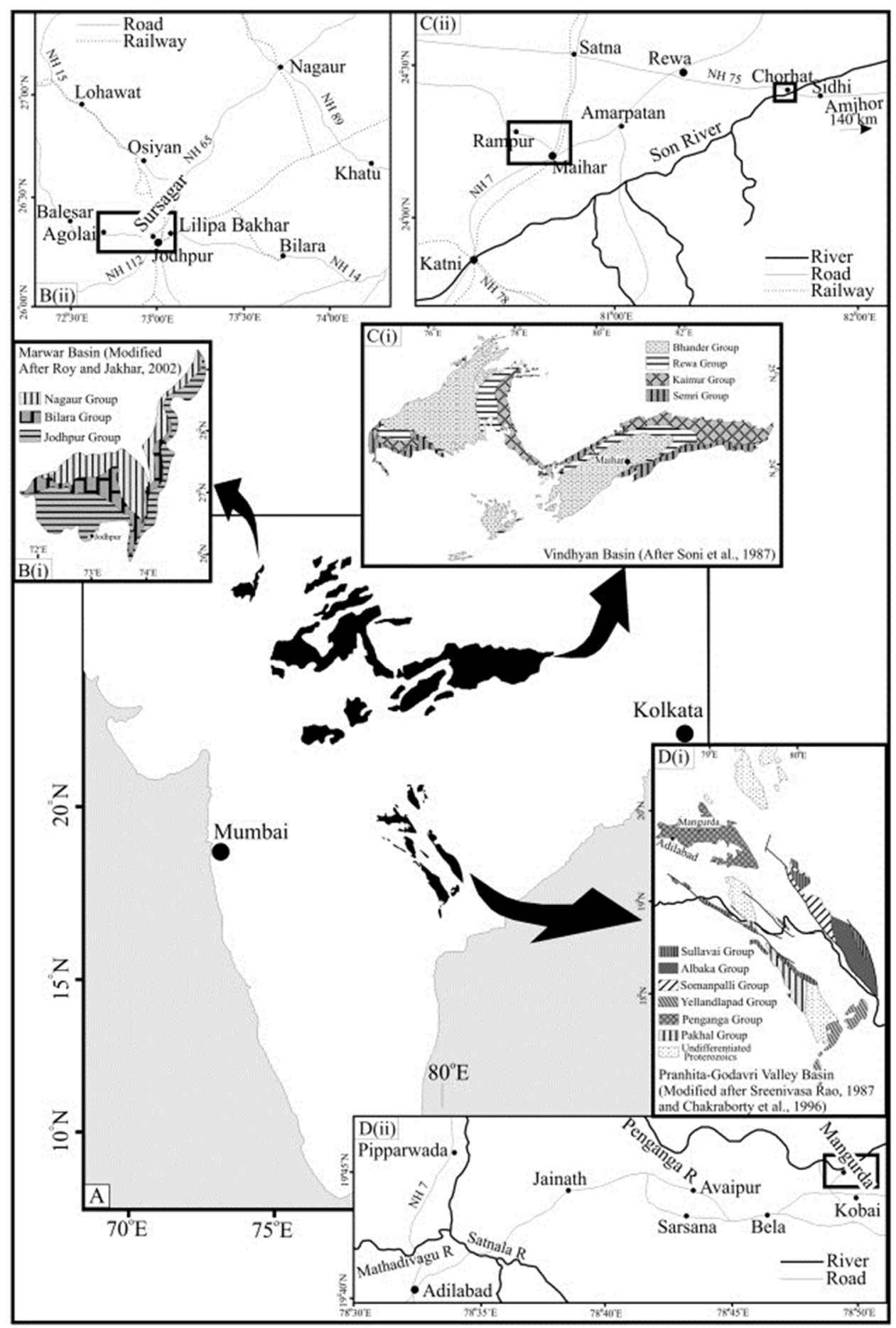

Figure 1 (A) Locations of Indian Palaeoproterozoic basins discussed in this paper. Geological sketch maps and locality maps for: (B) the Marwar basin; (C) the Vindhyan basin; and (D) the Pranhita-Godavari basin. 


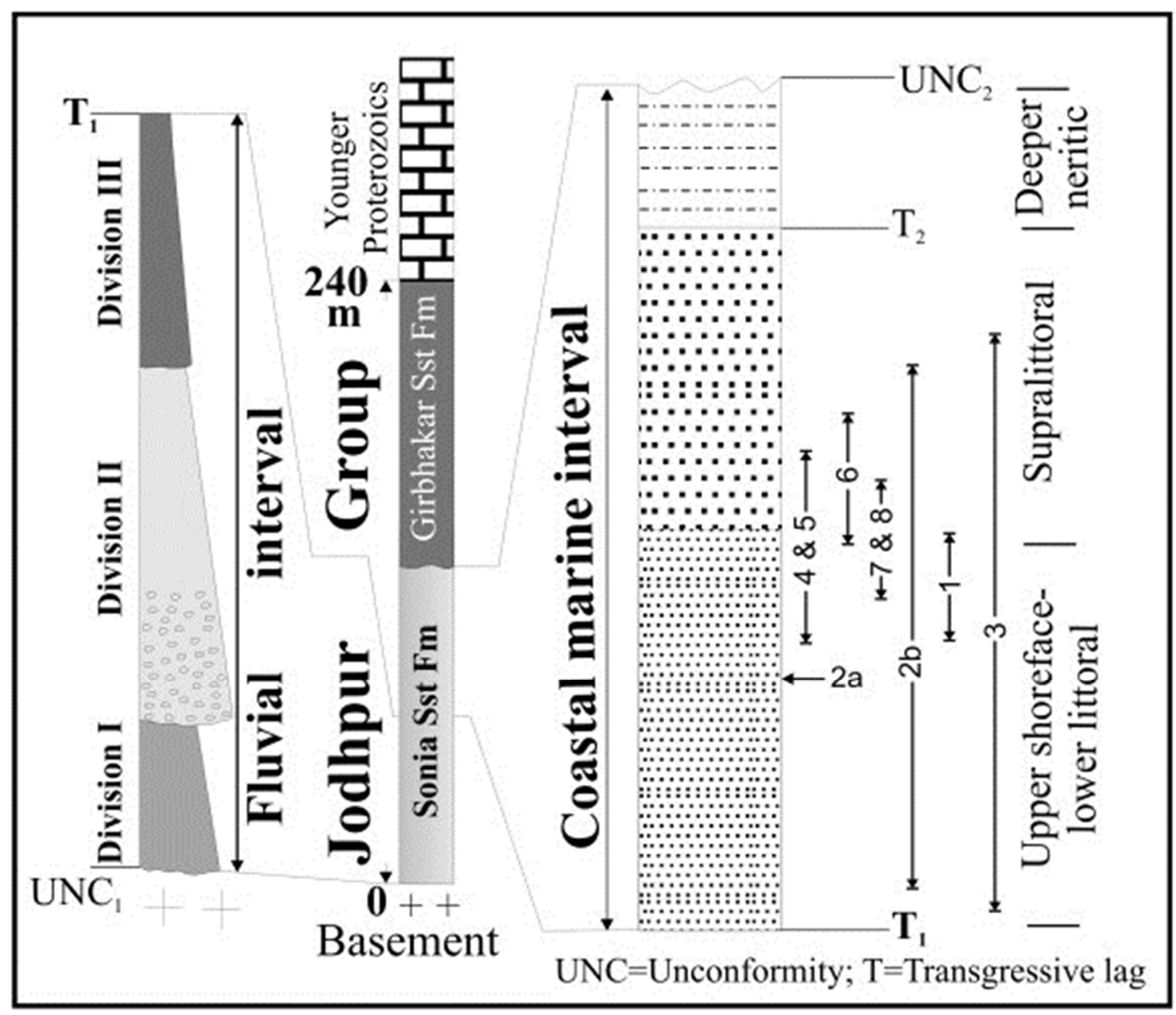

Figure 2 Temporal shift in palaeogeography-palaeoenvironment inferred for the Sonia Sandstone at the base of the Jodhpur Group, Rajasthan, India (see Fig. 1B for location). Note three divisions in the basal fluvial interval (left-hand column) and vertical variation in inferred marine palaeoenvironment (righthand column). The numbers adjacent to the right-hand column denote detailed categories of microbial mat features, as discussed in the text (Section 2.7): 1, 2a and $2 b=$ mat-layer structures (category 1 in Section 2.7): 1 = mat-layer discoidal; $2 a$ = mat-layer crumpled; $2 b=$ mat-layer wrinkled structures. 3,4 and $5=$ mat-induced structures (category 2 in Section 2.7): $3=$ mat-induced cracks along ripple crests, mat-induced surface cracks and mat-induced surface ridges; 4 and $5=$ mat-induced bulges. 6,7 and $8=$ mat-protected structures (category 3 in Section 2.7): $6=$ mat-protected setulfs; 7 = mat-protected ripples; 8 = mat-protected patchy ripples. Details are given in Sarkar et al. (2008). 


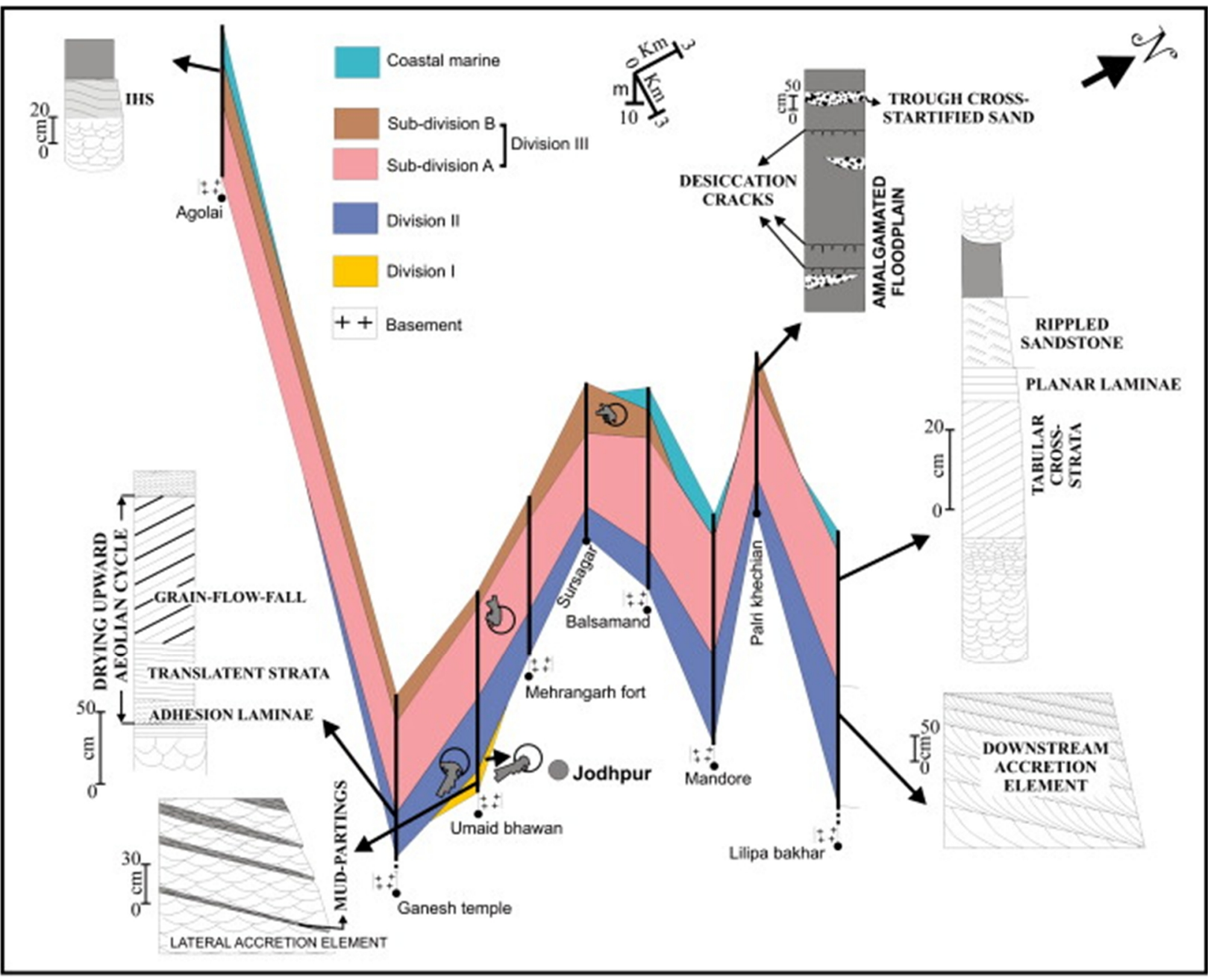

Figure 3 Fence diagram depicting lateral thickness variation of the three divisions of the fluvial interval at the base of the Sonia Sandstone, taking the base of the succeeding coastal marine interval as the datum plane (centre). The fluvial interval is bounded below by rhyolite basement and by the coastal interval above. Note palaeocurrent variation between the three divisions. Also note characteristic sedimentary features of the three divisions shown in the individual profiles. 

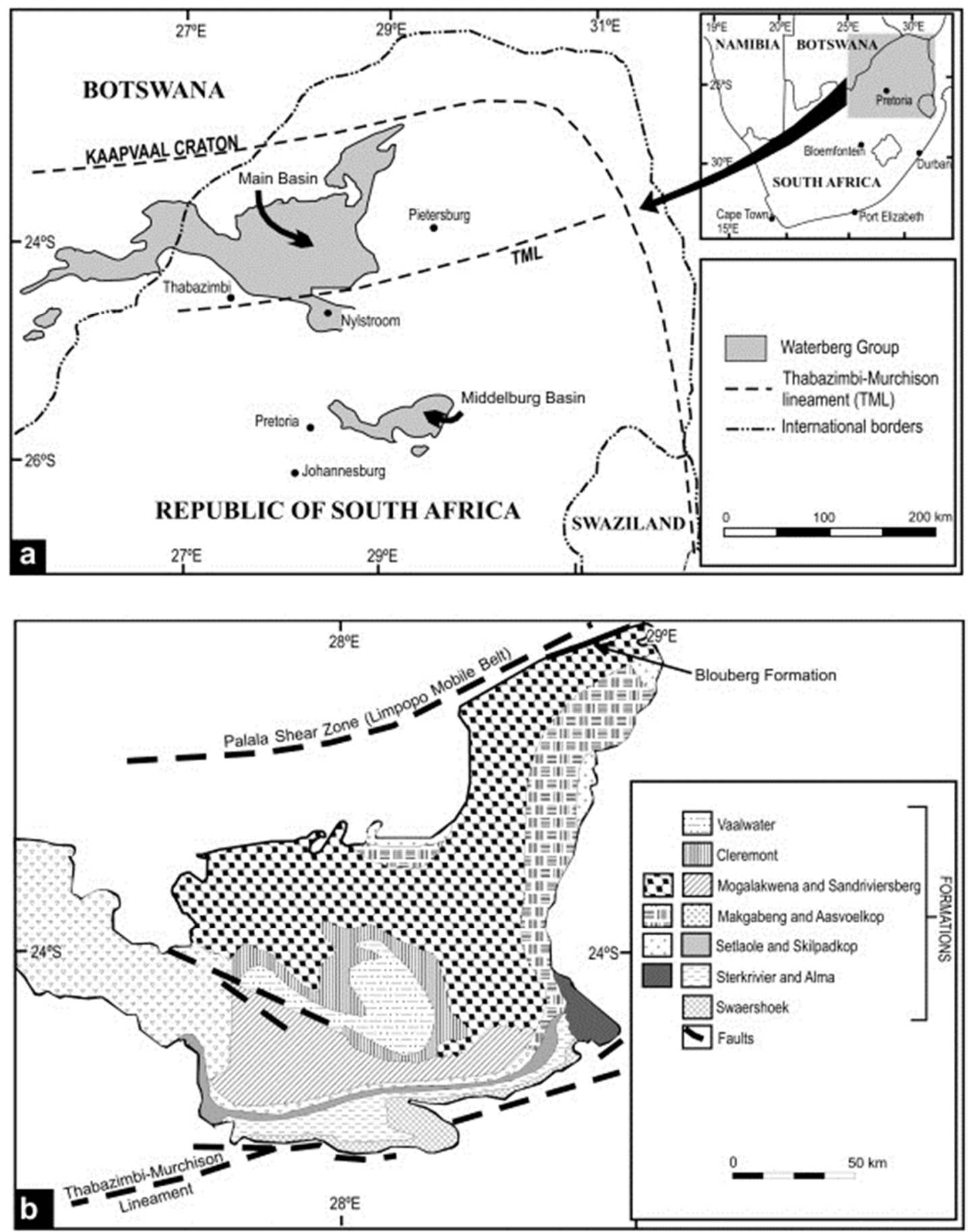

Figure 4 The Waterberg Group, preserved within South Africa in a Main basin and the smaller Middelberg basin (a) Sketch map of locations of these two basins, and their relation to major crustal architectural features of the Kaapvaal craton (b) Geological sketch map of the Main basin; note synsedimentary Vaalwater fault in the SW of the basin, and three pairs of correlated Formations: Setlaole-Skilpadkop, Makgabeng-Aasvoelkop, and Mogalakwena-Sandriviersberg. Modified after Callaghan et al. (1991) and Eriksson et al. (2006). 

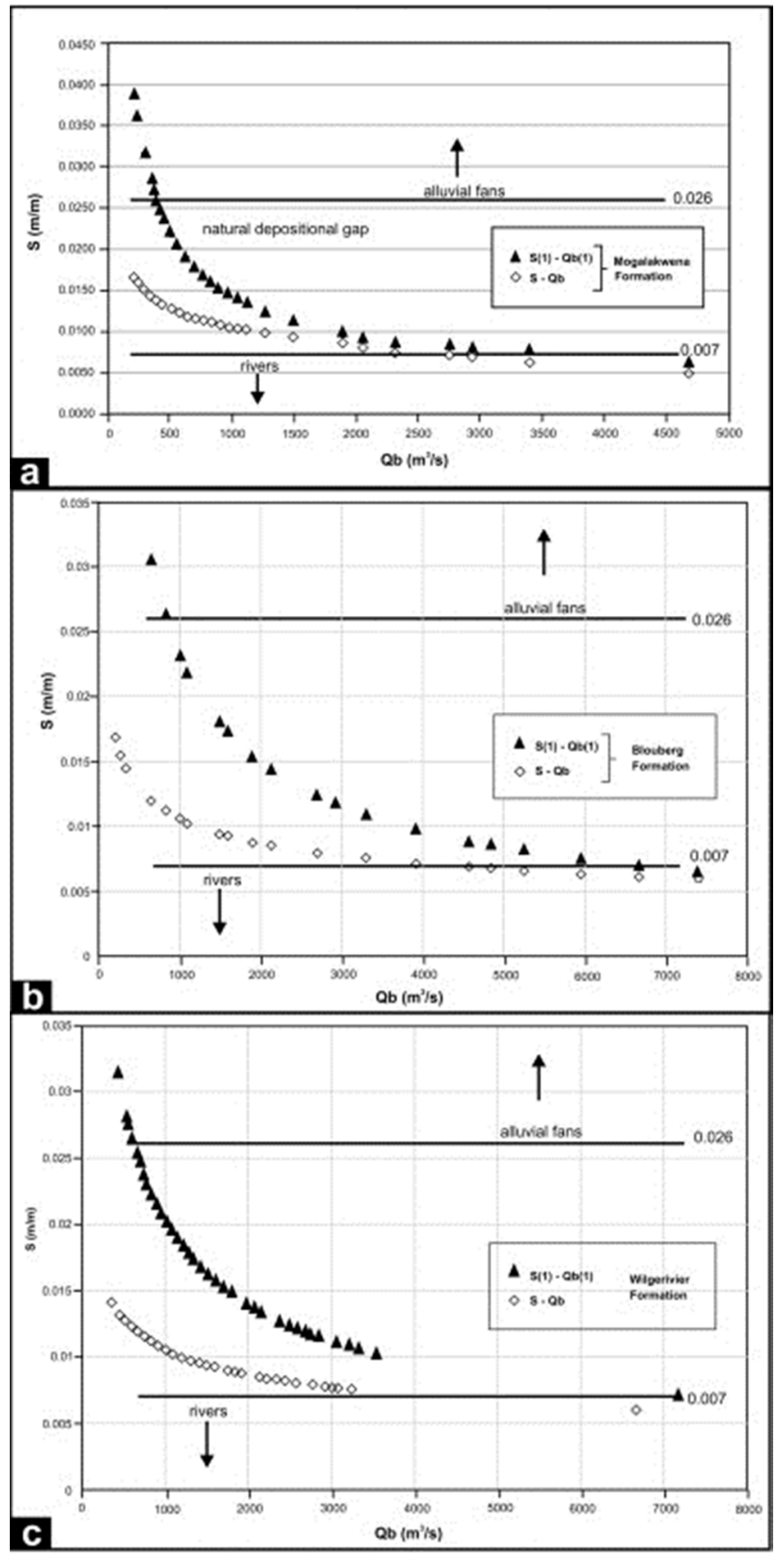

Figure 5 Binary plot of palaeohydrological values (methodology and the various parameters determined for the Waterberg rocks are discussed in detail in [Eriksson et al., 2008a] and [Eriksson et al., 2008b]) calculated for (a) the Mogalakwena Formation (b) the Blouberg Formation and (c) the Wilgerivier Formation of the Waterberg Group: palaeoslope $(S)$ versus mean annual bankfull discharge values $\left(Q_{b}\right)$. The two values of S (S and S[1]) reflect different equations within the standard palaeohydrological methodology. Note also the maximum gradient $(S)$ for rivers $(0.007 \mathrm{~m} / \mathrm{m})$ and the minimum gradient for alluvial fans $(0.026 \mathrm{~m} / \mathrm{m})$ of Blair and McPherson (1994). Note similarity of palaeoslope values for these three formations. 


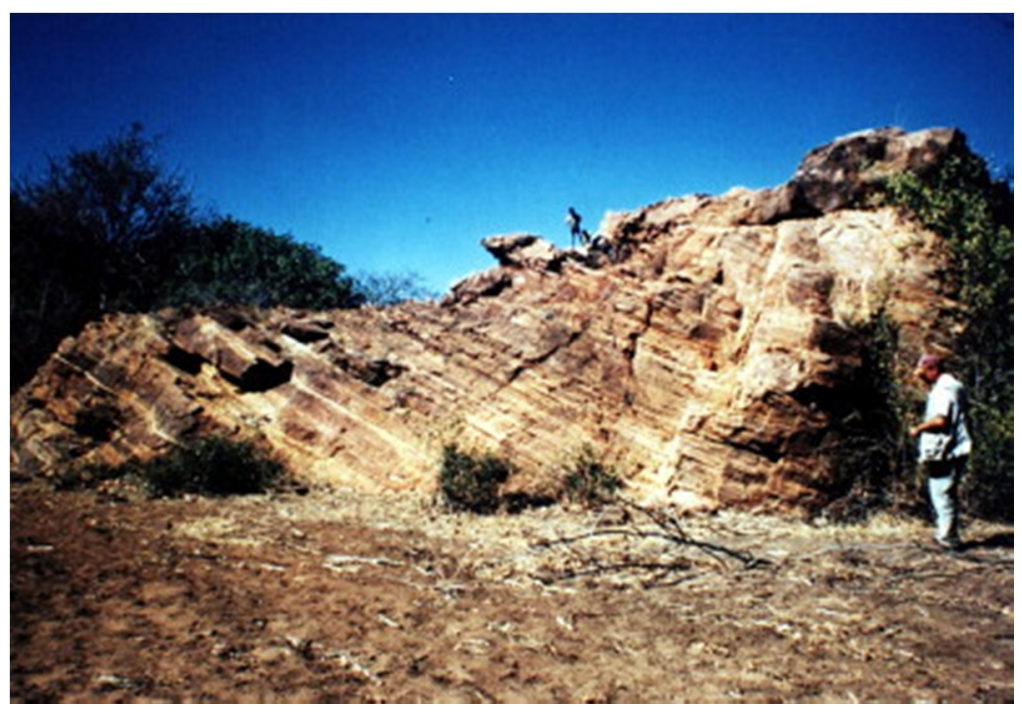

Figure 6 Field photograph of steeply inclined (foresets are close to $30^{\circ}$ to the bounding surfaces) planar cross-bedding in the Makgabeng Formation, Waterberg group; cross-bed foresets comprise inverselygraded aeolian laminae. View of photo is approximately at right angles to the dip direction (left to right). Makgabeng Plateau, Limpopo Province, South Africa; person in right foreground for scale.

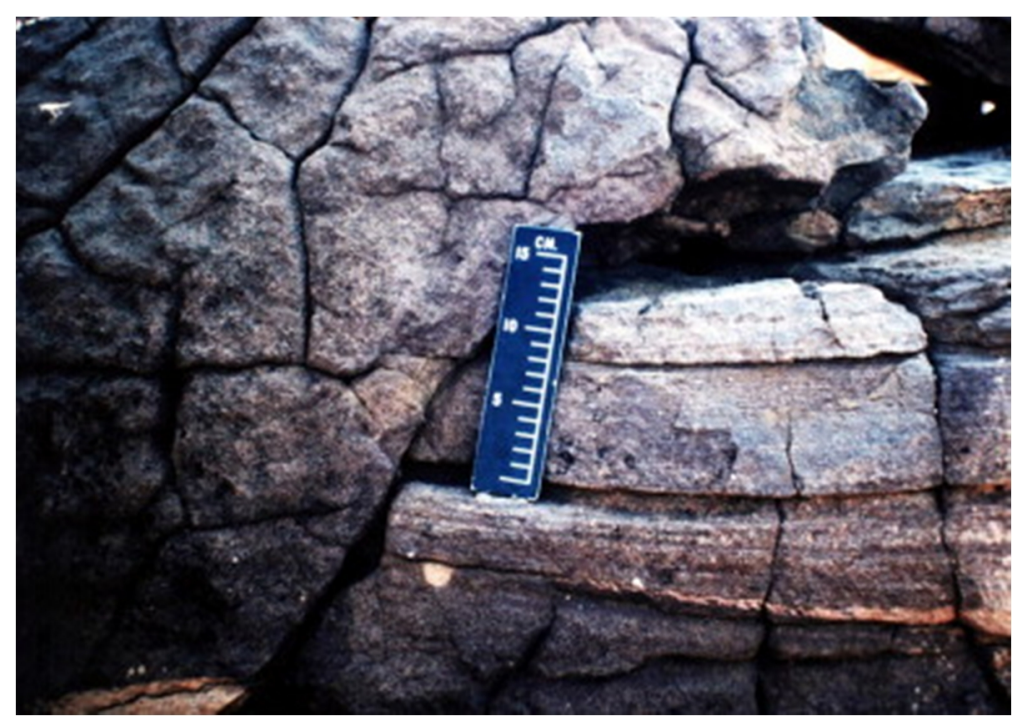

Figure 7 Localized erosively-based massive sandstone (with cracked weathering pattern in outcrop) cutting through low angle inversely-graded aeolian laminae in palaeo-dune toesets, Makgabeng Formation, Waterberg Group, South Africa. The massive sandstones are interpreted as the product of massive rainfall events resulting in hyperconcentrated flows which passed down dune lee faces, eroding them in the toesets (Simpson et al., 2002). Centimetric scale; location on Makgabeng Plateau, Limpopo Province. 


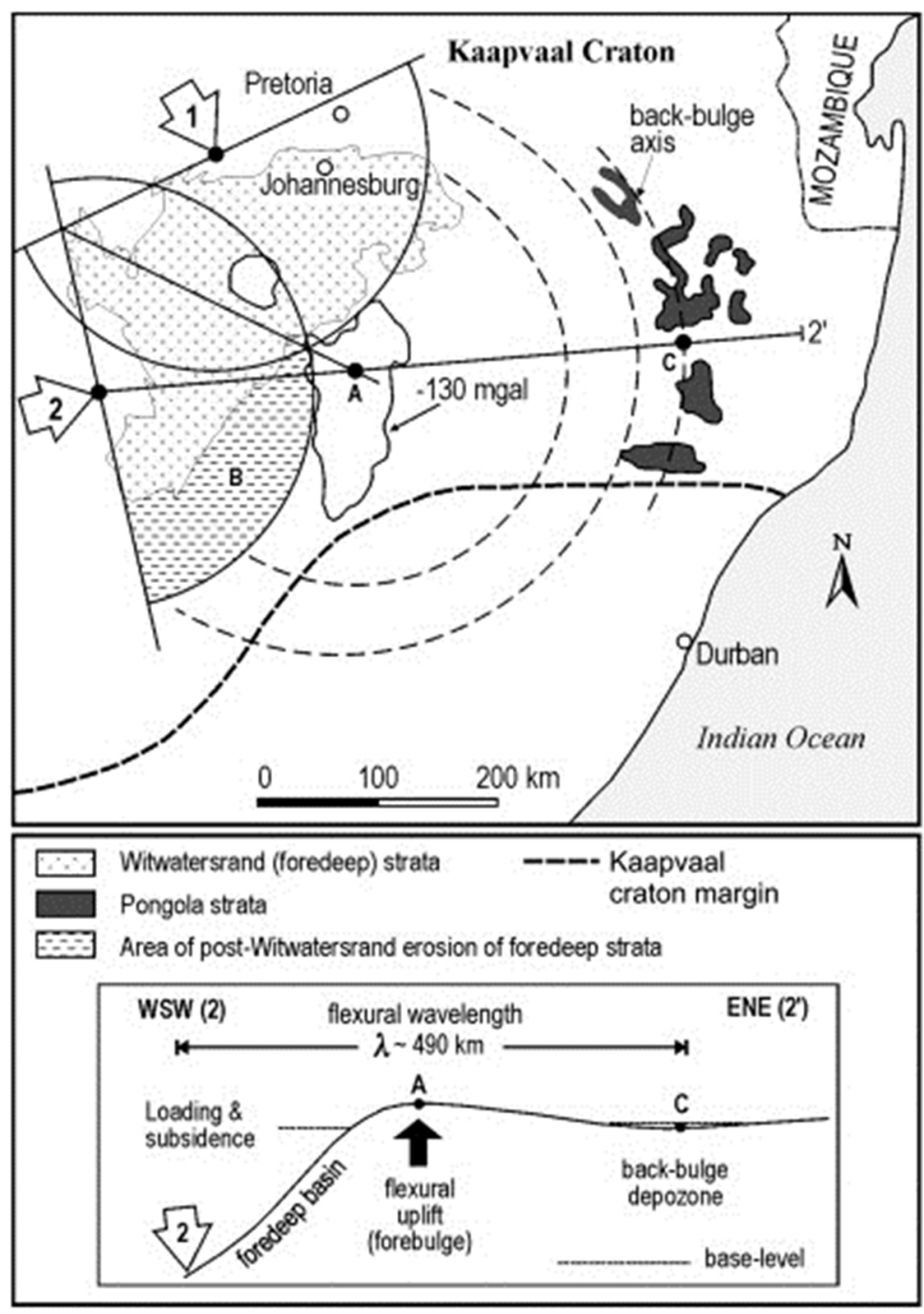

Figure 8 Sketch map (top) and schematic profile through inferred Witwatersrand foreland basin system (below). The preserved Witwatersrand basin equates to the foredeep depozone (foredeep sub-basin), with area " $B$ " representing an area of subsequent erosion of these foredeep strata. The two solid line half-circles, centred on the areas of maximum loading (numbered " 1 " and " 2 " for accreting northern and western composite terranes, respectively), outline the approximate distribution of the foredeep depozone. The forebulge developed outside the area covered by these two half-circles, with its apex, point " $A$ " (see in map and profile below) enclosed by the $-130 \mathrm{mgal}$ isoline of the gravity field. The three dashed circles suggest contour lines of the foreland system centred around the forebulge apex (at A), with the outermost such circle marking the position of the backbulge sub-basin axis (which equates with the depo-axis of the Pongola Supergroup basin), as suggested in theoretical flexural profile models (cf. Catuneanu, 2001 and references therein). In the case of the greater Witwatersrand basin, the forebulge remained emergent, separating discrete foredeep (filled by the Witwatersrand Supergroup) and backbulge (filled by the Pongola Supergroup) sub-basins. The cross-sectional profile $2-2$ ' on the map is shown below in the profile. Modified after Catuneanu (2001). 


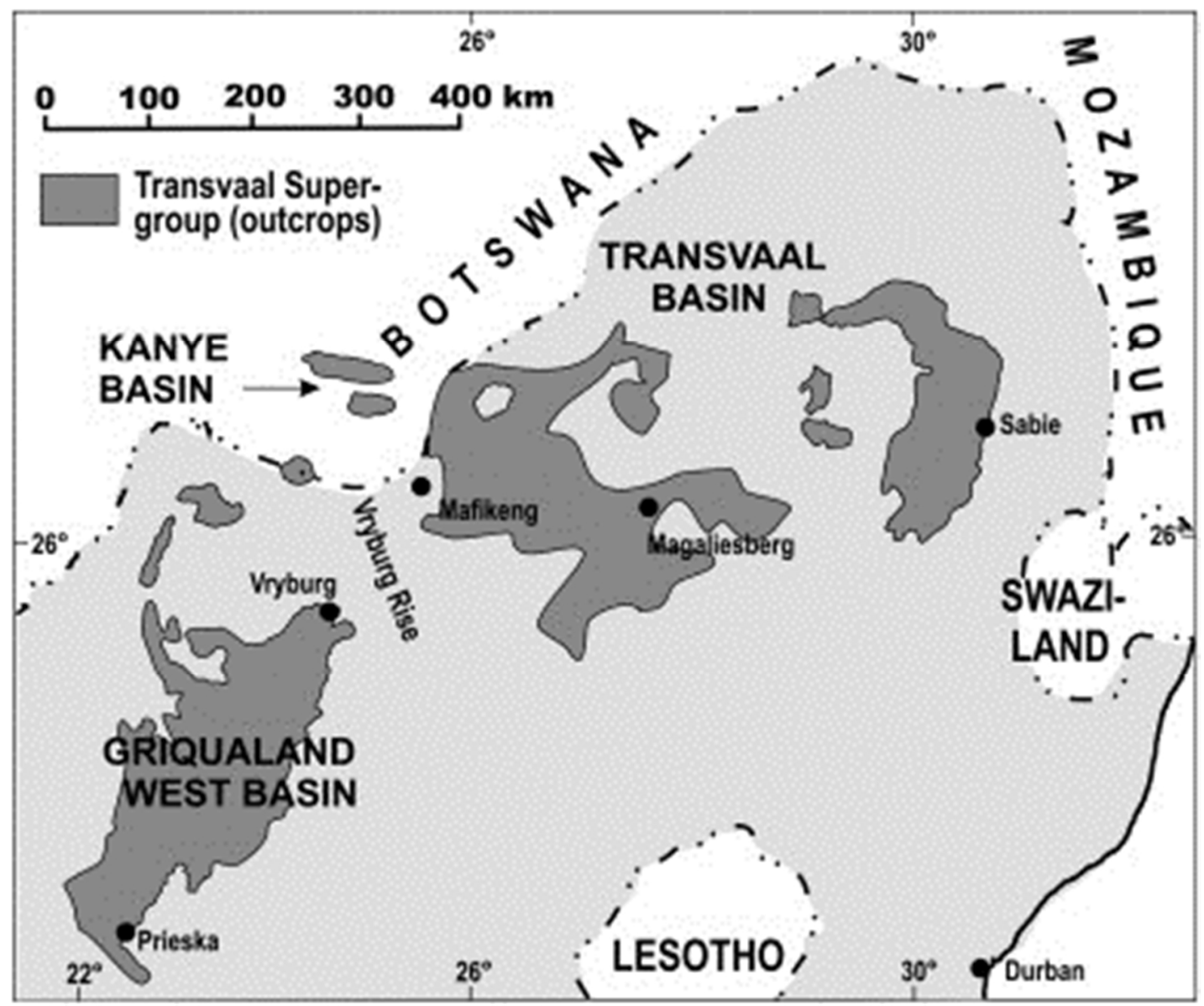

Figure 9 Sketch map showing the three Transvaal (Supergroup) sub-basins: Transvaal itself and Griqualand West, separated by the Vryburg Rise, a palaeohigh, with the Kanye to the north of this feature. 


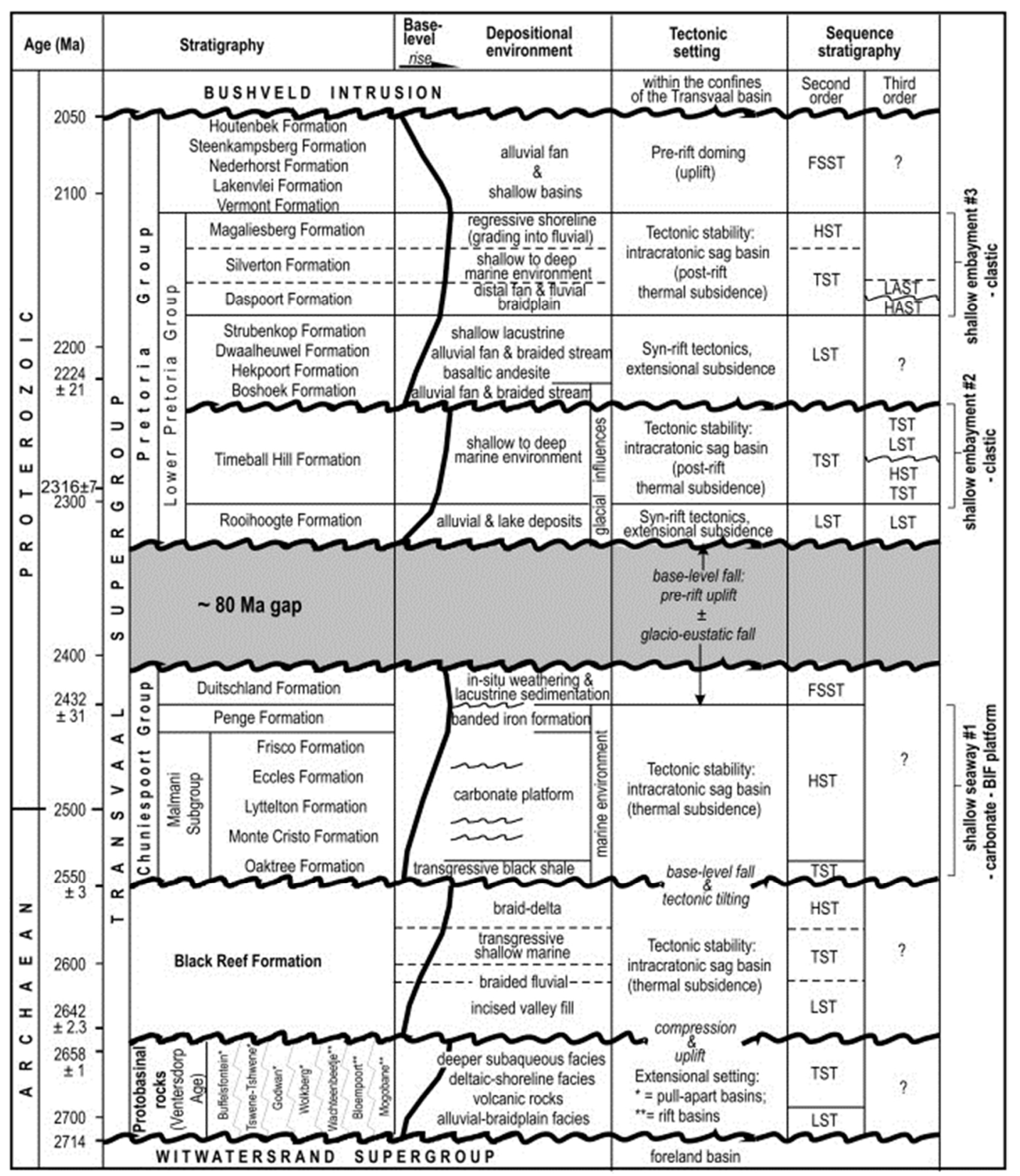

Figure 10 Schematic summary figure of stratigraphy, inferred depositional palaeoenvironments, tectonic settings and interpreted sequence stratigraphy for the Transvaal Supergroup within the Transvaal preservational basin (modified after [Catuneanu and Eriksson, 1999] and [Eriksson et al., 2001b]; see latter for geochronological detail and references). Note four main subdivisions of the basin-fill: "protobasinal rocks" at the base, Black Reef Formation, Chuniespoort Group, and uppermost Pretoria Group; also major unconformity at base of Pretoria Group. Note also, three inferred epeiric settings: a shallow carbonate-BIF epeiric seaway interpreted for the Chuniespoort Group, and two postulated clastic epeiric embayments at the levels of the Rooihoogte-Timeball Hill Formations and the Daspoort-Silverton-Magaliesberg Formations (far right of figure). Wavy lines suggest unconformable contacts. Abbreviations: LST = lowstand systems tract; TST = transgressive systems tract; HST = highstand systems tract; FSST = falling stage systems tract; LAST = low accommodation systems tract; HAST = high accommodation systems tract. 

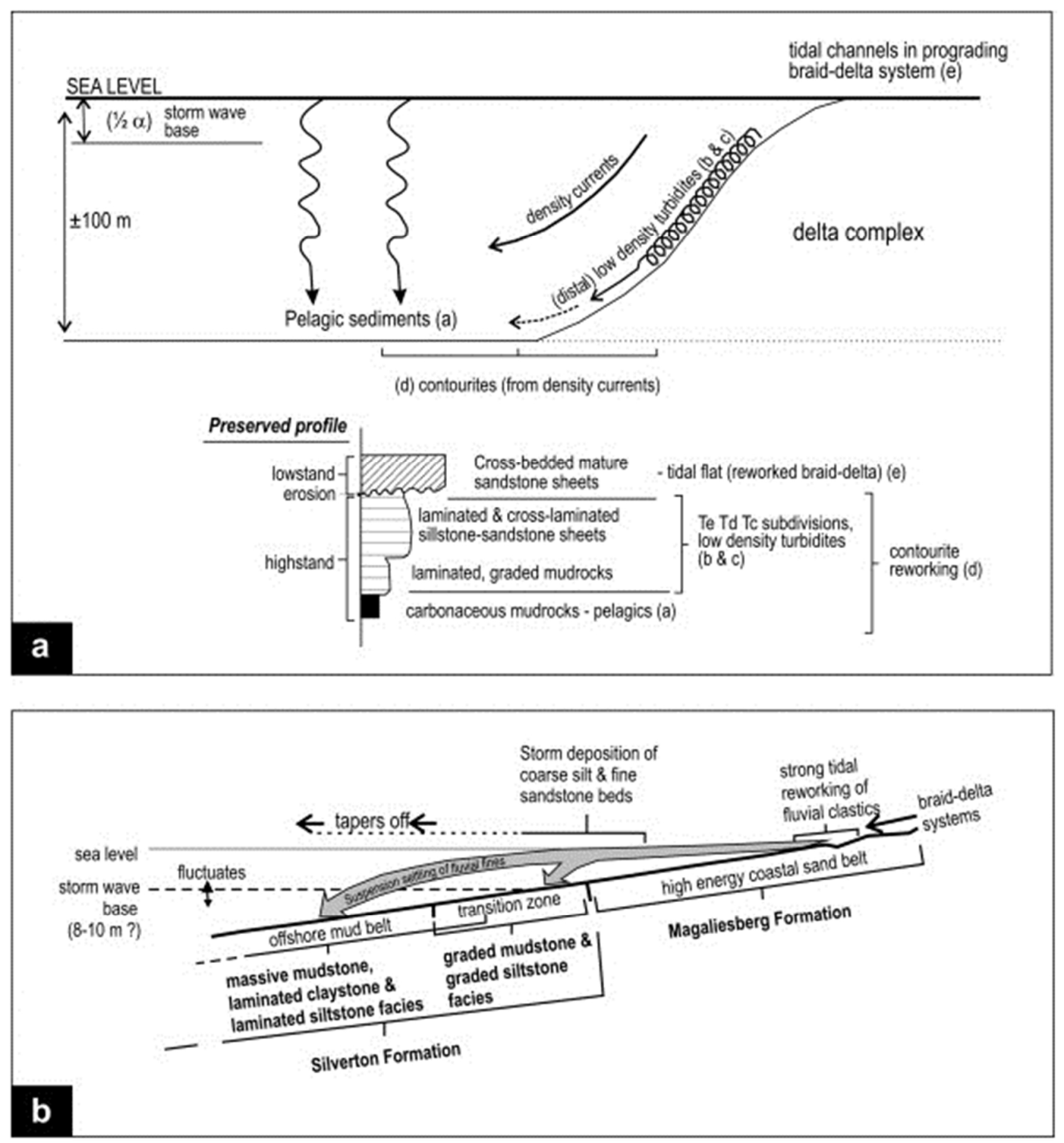

Figure 11 Clastic epeiric embayment models interpreted for: (a) the Timeball Hill Formation and (b) the Silverton-Magaliesberg Formations, both of the Palaeoproterozoic Pretoria Group, Transvaal Supergroup (modified after [Eriksson and Reczko, 1998], [Eriksson et al., 2002] and [Eriksson et al., 2004d]). 

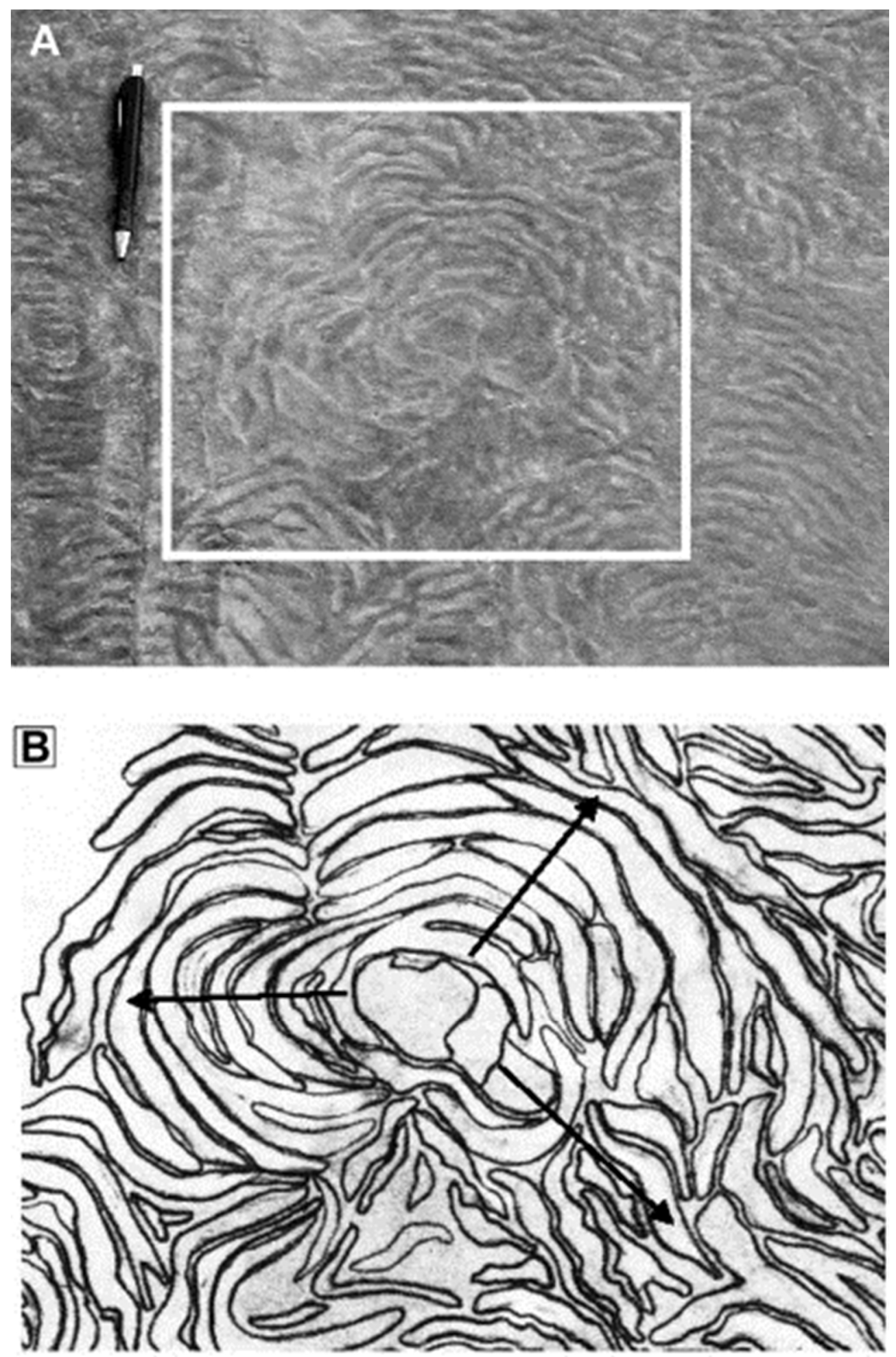

Figure 12 Mat ground, preserved intact, displaying a radial arrangement of laterally linked curved spindles (pen length $14 \mathrm{~cm}$ ) (A). Sketch made from A, detailing stromatolite-like lateral accretion (B). 

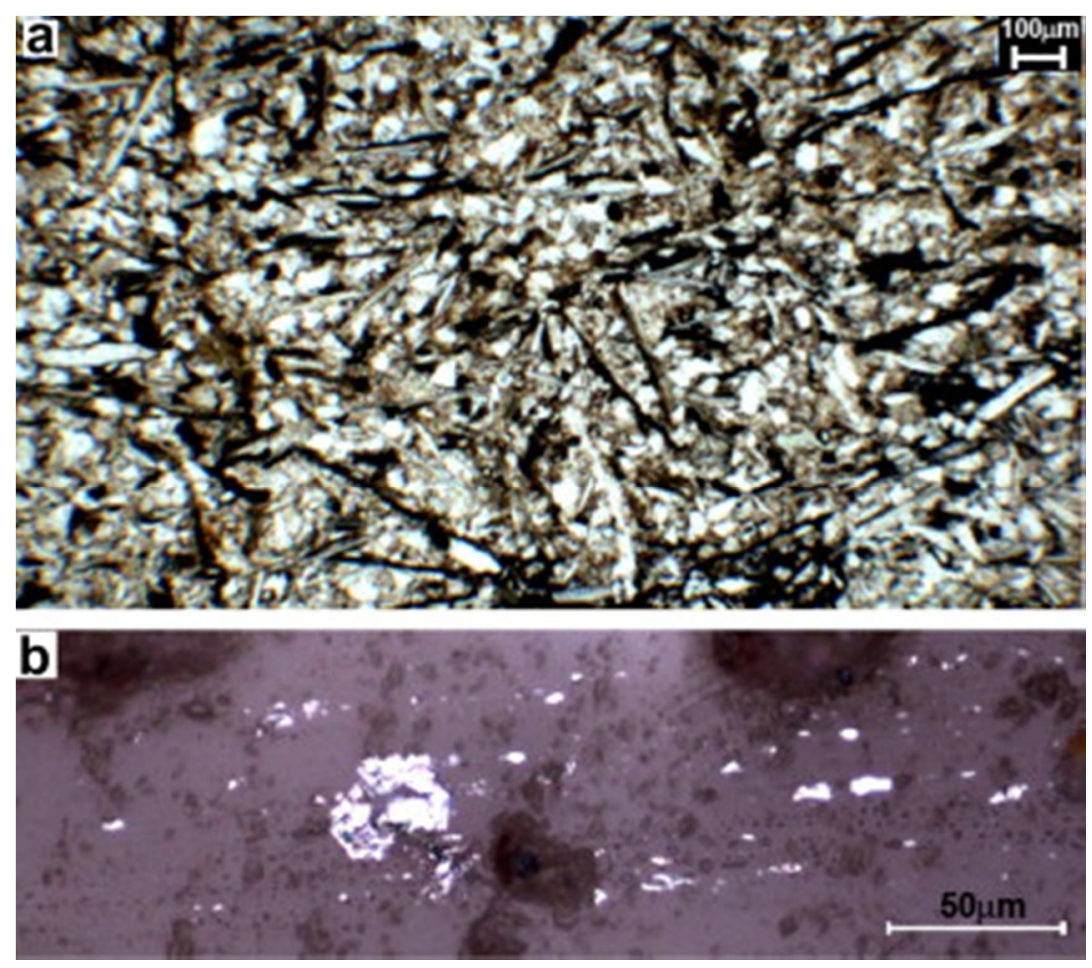

Figure 13 Hapazardly oriented platy minerals in fine-grained veneer on coastal marine bed surfaces in the Sonia Sandstone, depicting "fly-paper" effect (a); early diagenetic pyrite in clustured and also in disseminated form within the marine interval of the Sonia Sandstone (b).

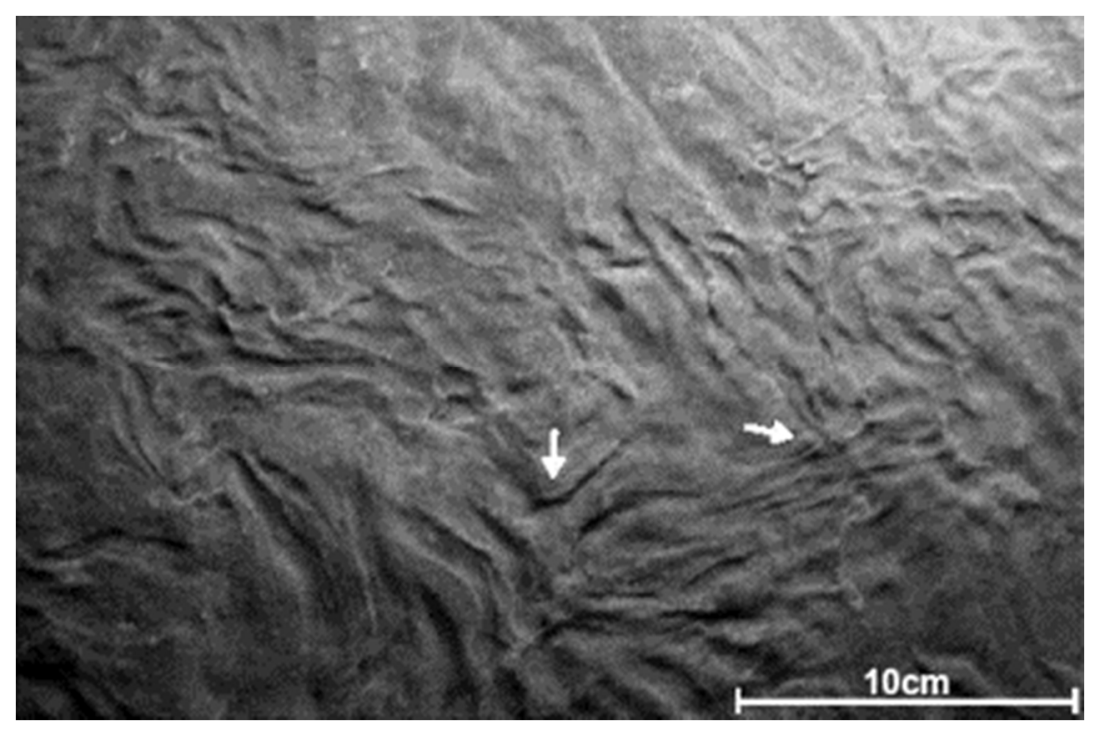

Figure 14 Crumpling feature on a sandstone bed surface within the coastal marine interval of the Sonia Sandstone. Note the minor drag folds in diverse directions (arrows). 


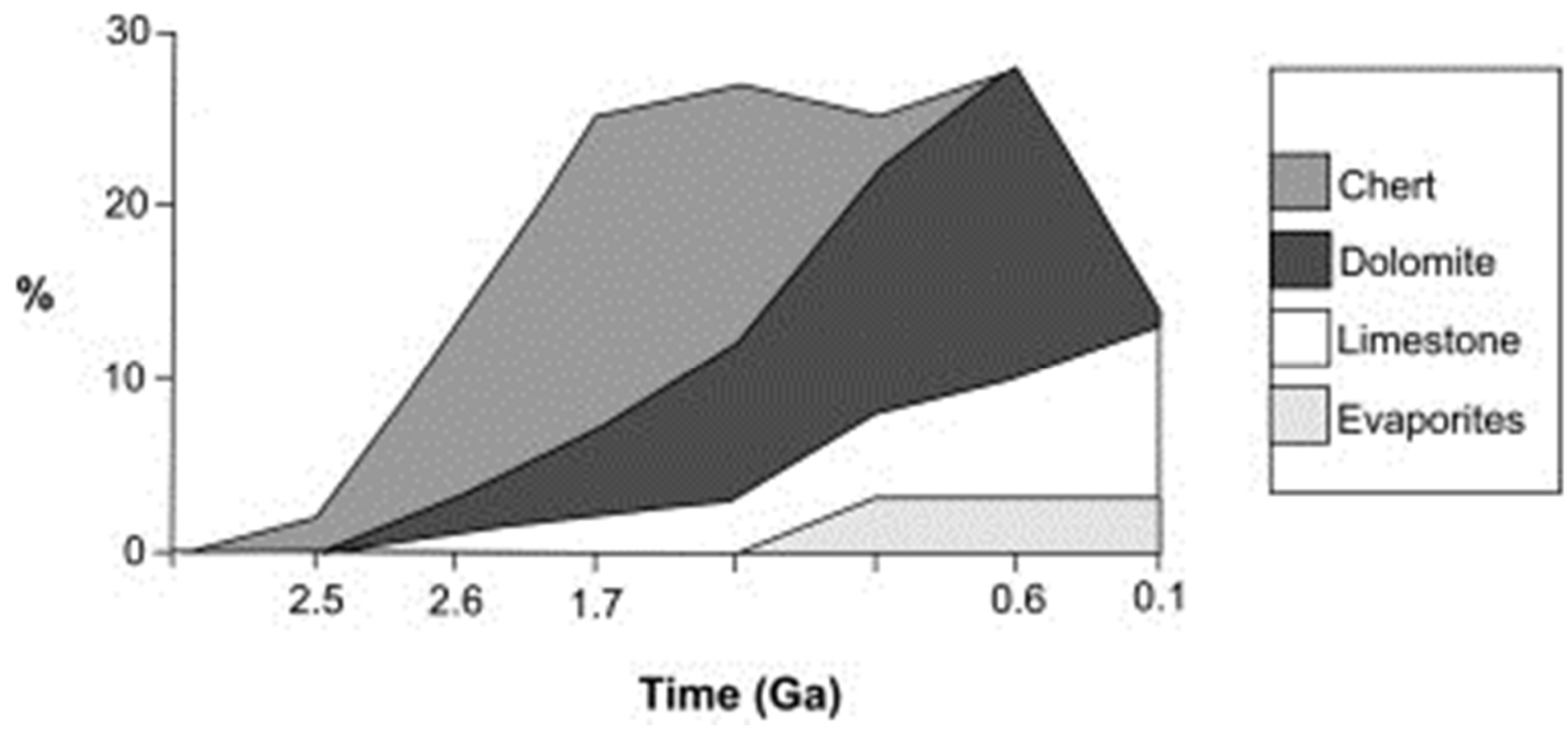

Figure 15 The relative abundance of non-siliciclastic sediments through time, showing dolomites to be much more abundant than limestones in the Proterozoic, when microbial ecosystems dominated the biosphere. Modified after Ronov (1965).

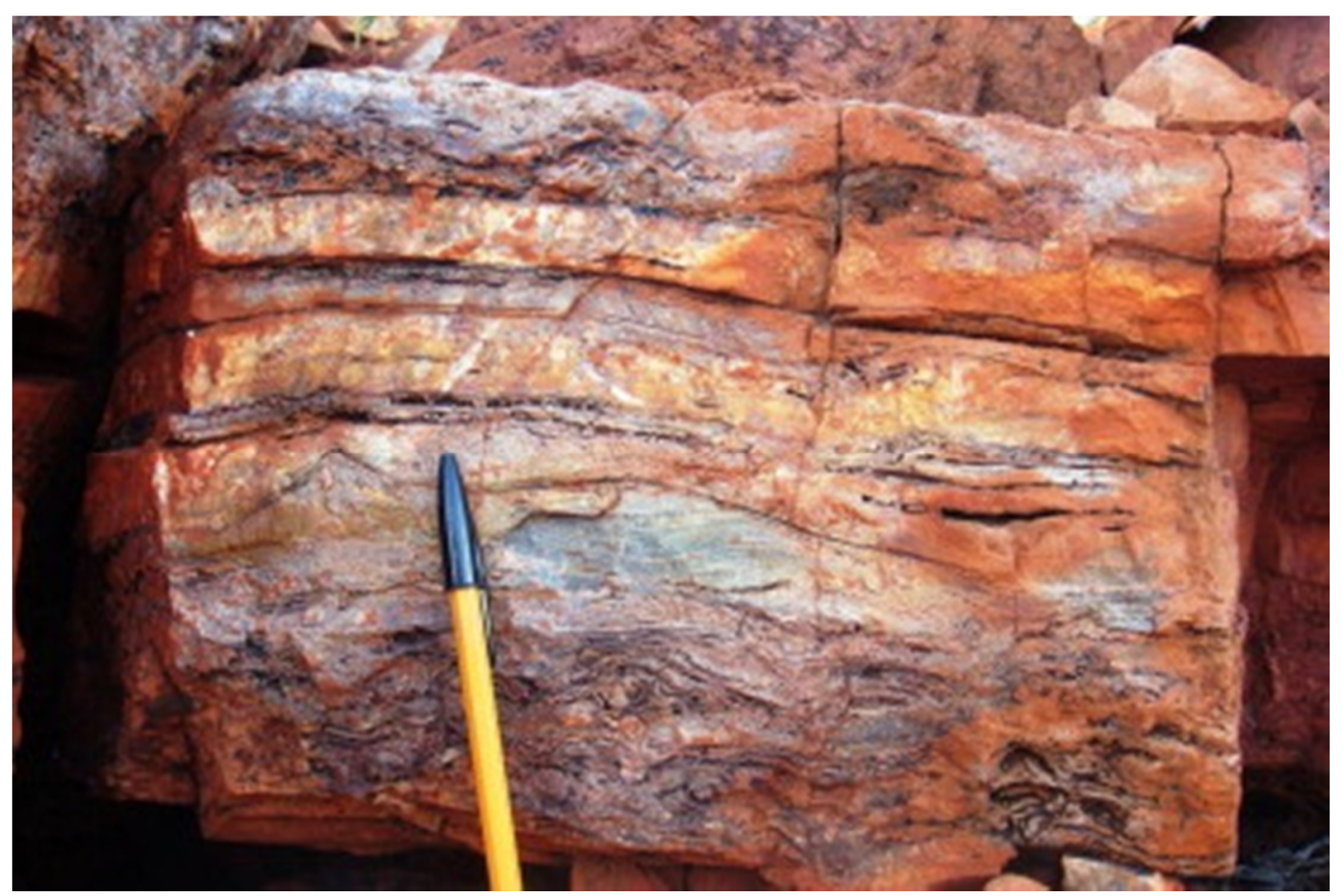

Figure 16 Cross-bedding and ripples in silicified carbonate rocks of the c. 3.5 Ga Dresser Formation, Warrawoona Group in the North Pole Dome area of the Pilbara craton. Pen for scale. 


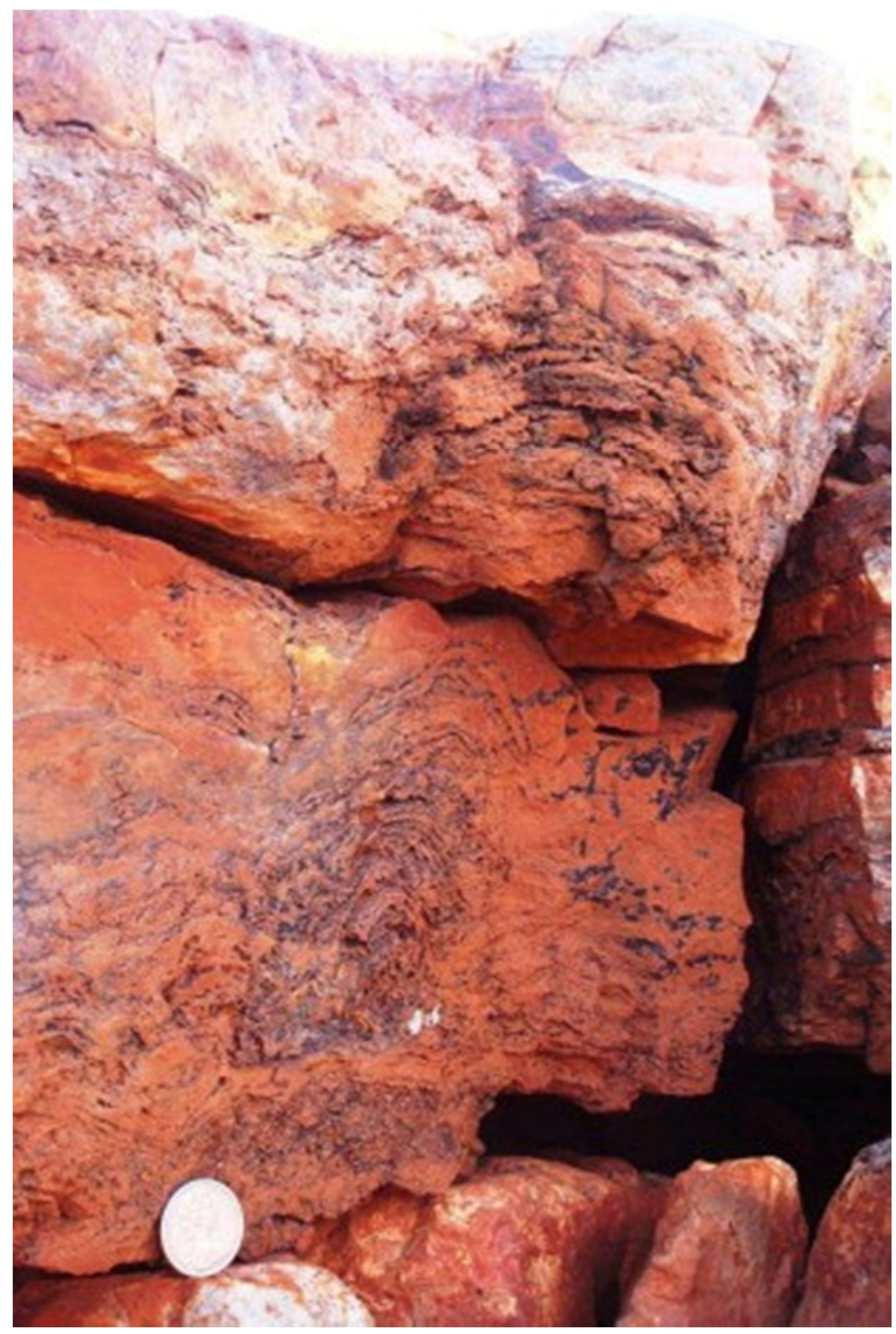

Figure 17 A number of stromatolitic structures are found in the c. 3.5 Ga Dresser Formation (Pilbara craton) - here, partially silicified wrinkly stromatolites pass laterally into domical forms. Coin for scale. 


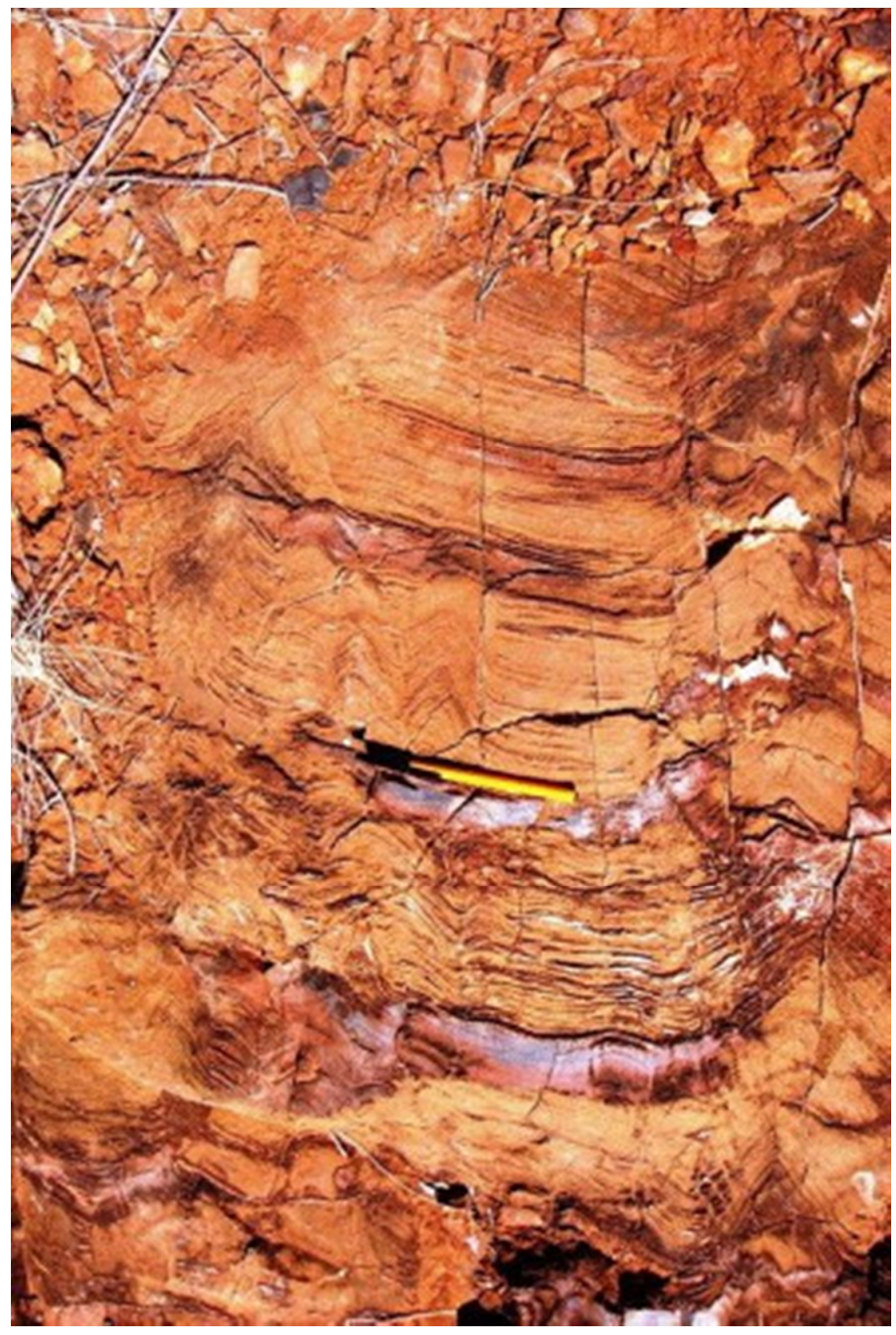

Figure 18 Steep-sided coniform stromatolites of the Strelley Pool Chert at the Trendall locality, Shaw River, Pilbara, Western Australia, showing both persistent and limited vertical continuity between laterally flat- and undulatory-laminated areas. The complex changes in form suggest competitive response to minor variabilities in biochemical conditions (e.g., chemical gradients, nutrient supply, light availability). 


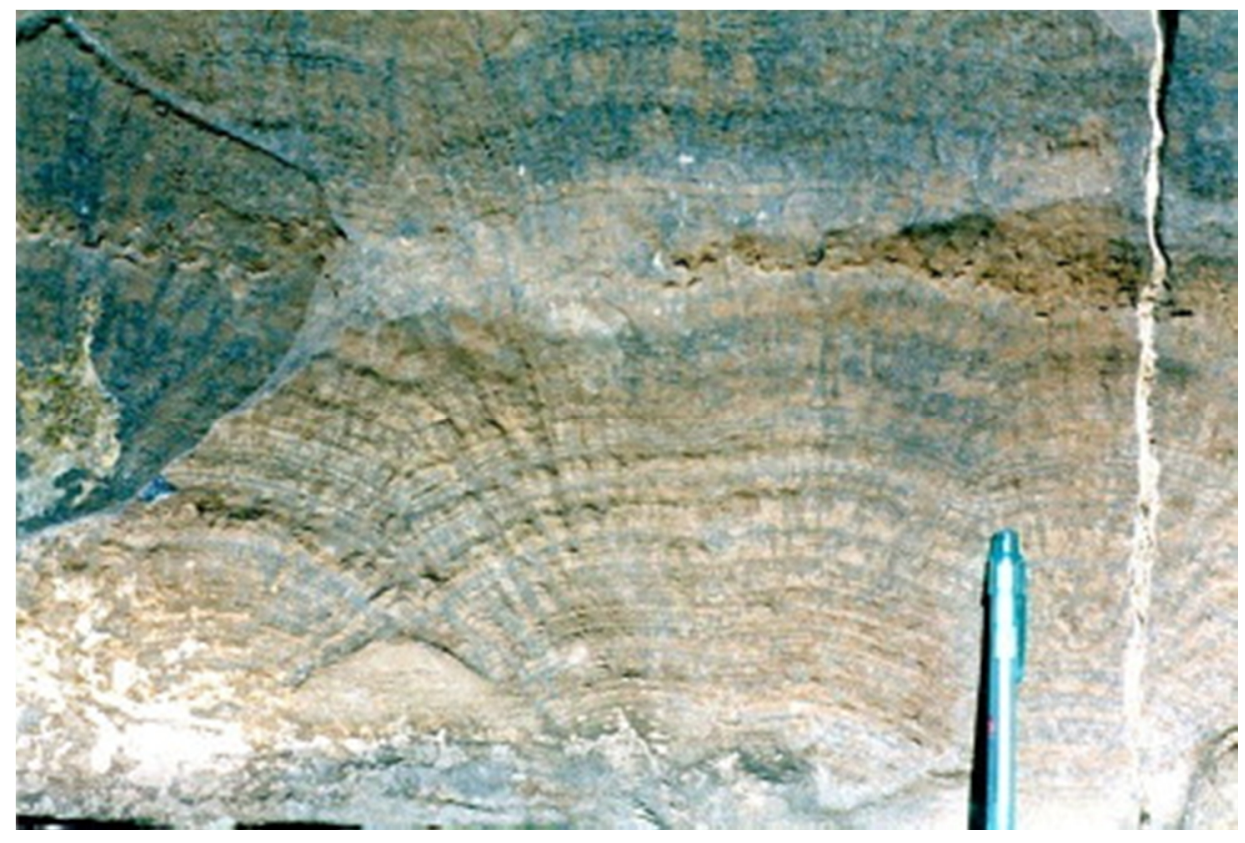

Figure 19 'Crystal fans' from the Neoarchaean Reveilo Formation, Campbellrand Subgroup, South Africa. Originally interpreted as carbonate replacive of gypsum, they were later considered to be replacive after aragonite (Sumner and Grotinger, 1996). Hardie (2003) and Gandin et al. (2005) have since argued that the fans were in fact originally gypsum. Pen for scale.

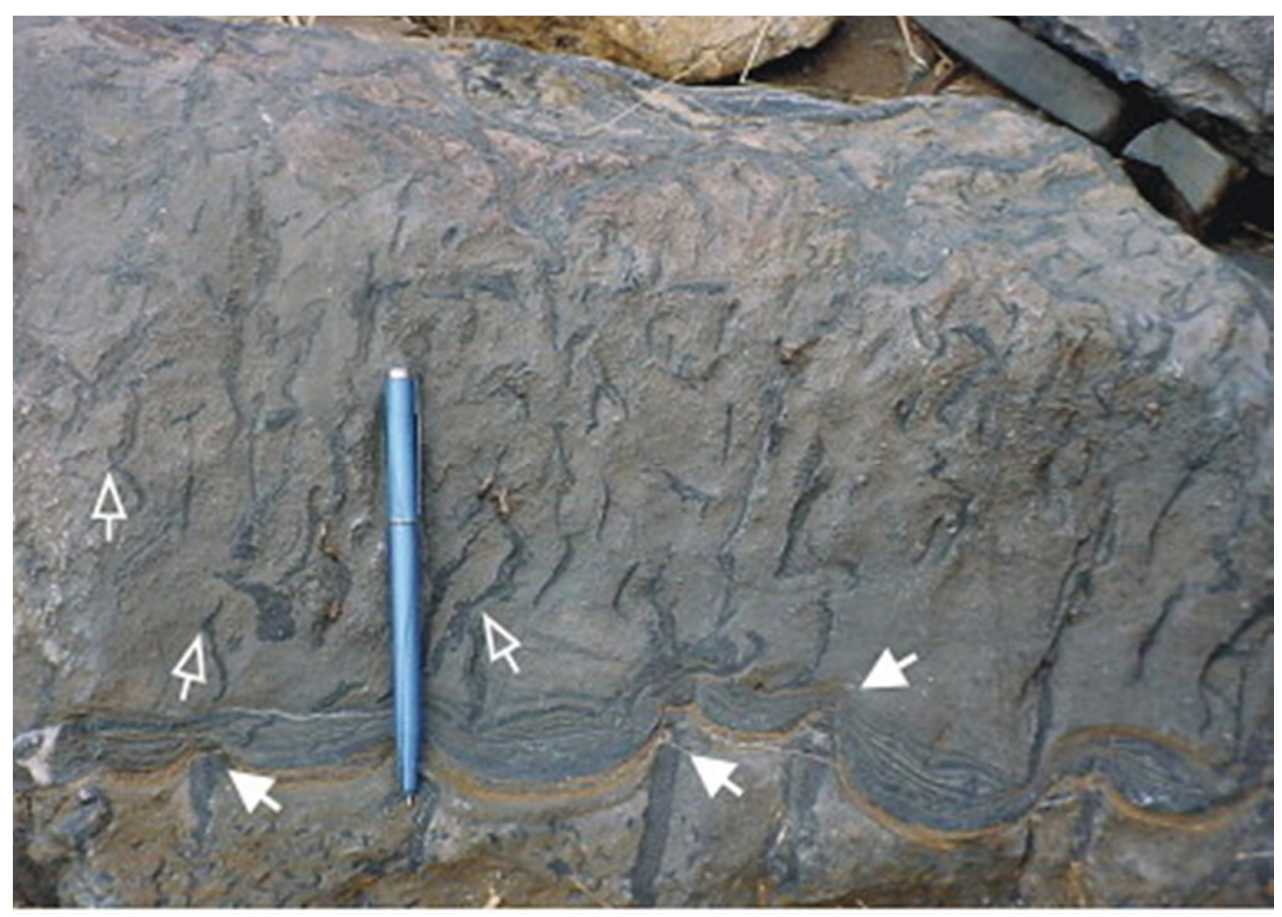

Figure 20 Swarms of molar tooth structures (oblique view) from the Mangurda Limestone, PranhitaGodavari valley. Note ptygmatic folding within some of them (open arrows) and evidence of differential compaction against some of the vertically oriented structures (solid arrows). 


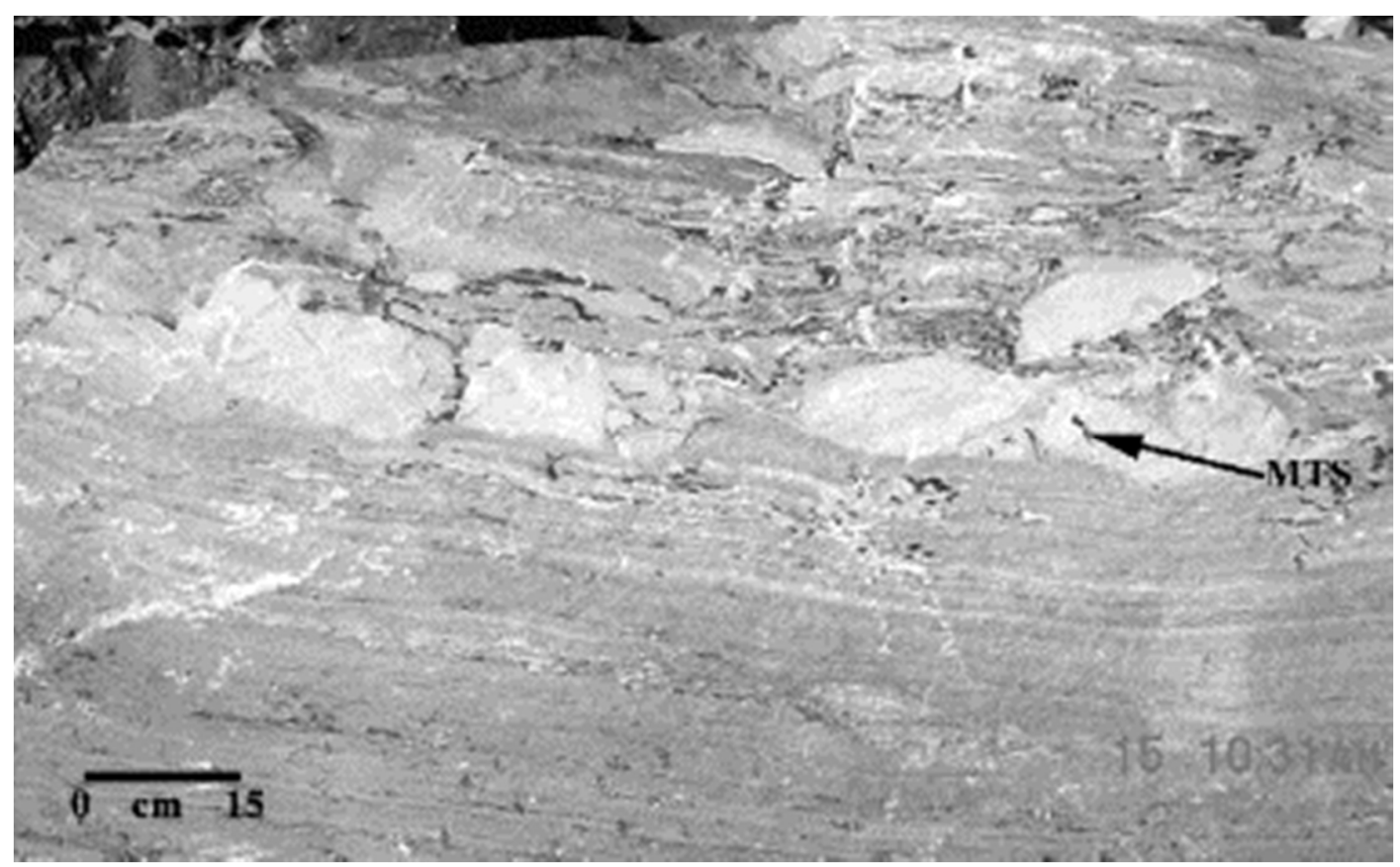

Figure 21 Thinly interlaminated marl-limestone facies of the Bhander Limestone, India, with darkcoloured molar tooth structure in its upper, "shredded" part (arrow).

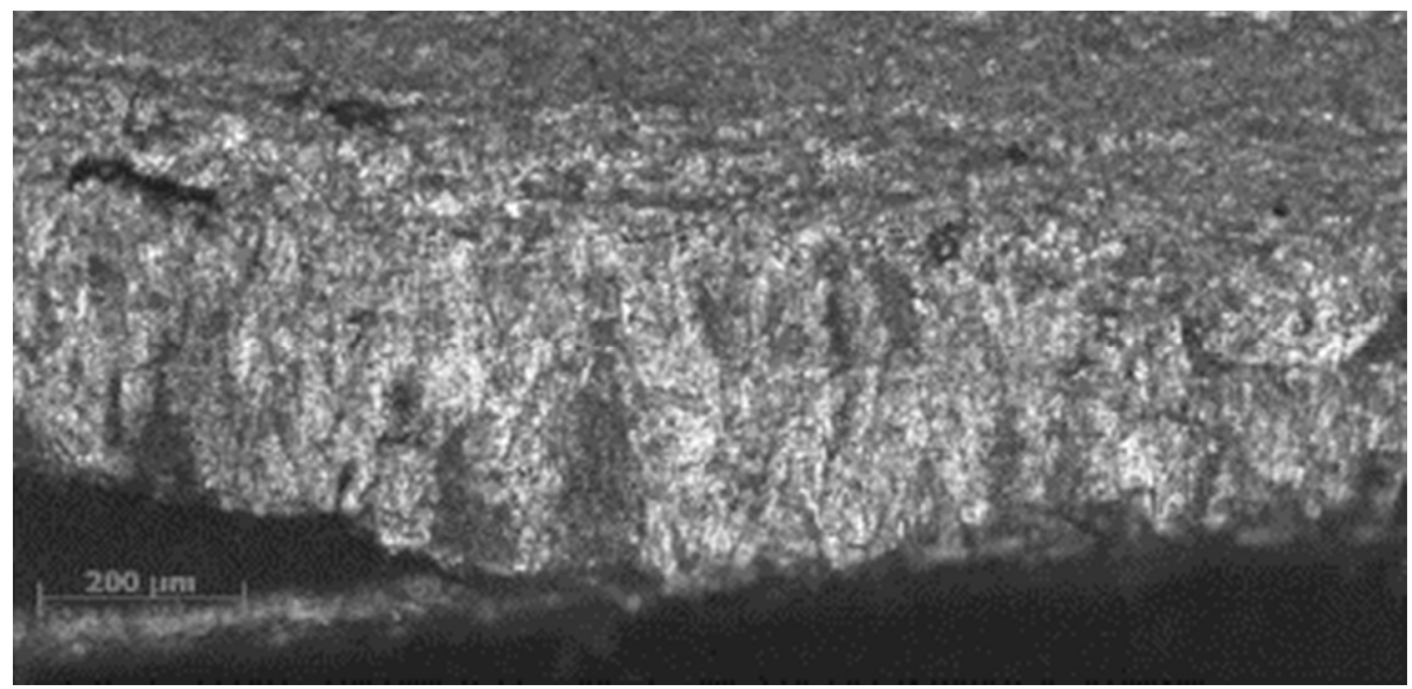

Figure 22 Swallow-tail structure in pseudomorphs after gypsum, found in close association with molar tooth structure within the Bhander Limestone, India. 


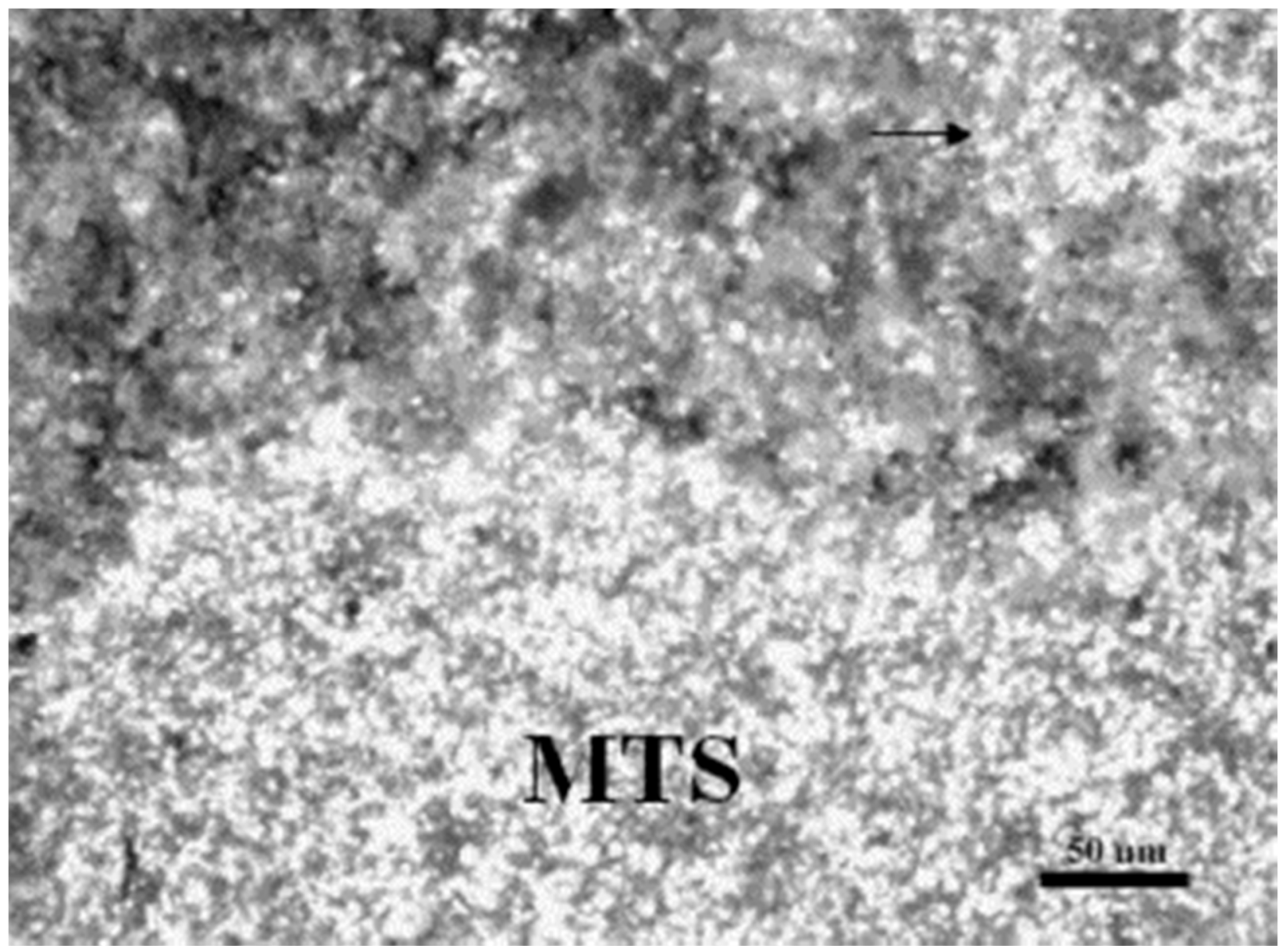

Figure 23 Under cathode luminescence, molar tooth structure (MTS) displays brighter illumination than the groundmass within the Mangurda Limestone, India. However, bright MTS crystals are sparsely distributed (arrow) within the groundmass as well.

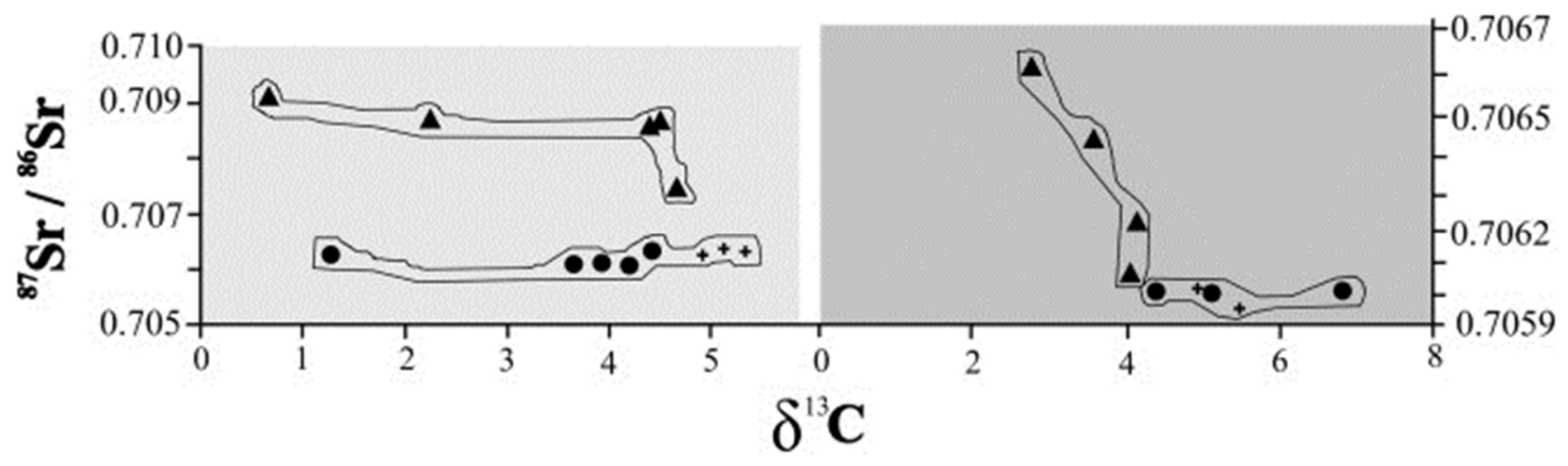

Figure $24{ }^{87} \mathrm{Sr} /{ }^{86} \mathrm{Sr}-\delta^{13} \mathrm{C}$ relation for 1 st generation molar tooth structure (MTS) (cross symbol), 2nd generation MTS (circles) and the sediment that hosts them (triangles), in the Bhander Limestone, at left, and in the Mangurda Limestone, at right. Note significant difference between the MTS population and the host sediment for both the limestone formations. 